\title{
Pedagógiatörténeti Szemle
}

Az MTA Pedagógiai Tudományos Bizottsága

Neveléstörténeti Albizottságának folyóirata

2. évfolyam

1-2. szám

2016 


\section{Impresszum}

Főszerkesztő: Pukánszky Béla

SZTE JGYPK Gyógypedagógus-képző Intézet

6725 Szeged, Hattyas u. 10.

bela@pukanszky.hu

Szerkesztôbizottság: Kéri Katalin, Németh András, Szabolcs Éva Nemzetközi tudományos board:

Prof. Dr. Rotraud Coriand, Universität Duisburg-Essen

Prof. Dr. Lucien Criblez, Universität Zürich

Prof Dr. Gerald Grimm, Alpen-Adria-Universität, Klagenfurt

Prof. Dr. Johanna Hopfner, Karl-Franzens-Universität Graz

Prof. Dr. Klaus-Peter Horn, Georg-August-Universität Göttingen

Dr. Tomáš Kasper, Technická univerzita v Liberci

Prof. Dr. Iveta Kestere, Latvijas Universitate

Prof. Dr. Christine Mayer, Universität Hamburg

Prof. Dr. Simonetta Polenghi, Univ. Cattolica del Sacro Cuore, Milano

Prof. Dr. Edvard Protner, Univerza v Mariboru

Prof. Dr. dr. hc. Ehrenhard Skiera, Universität Flensburg

Prof. Dr. dr.hc. Heinz-Elmar Tenorth, Humboldt Universität zu Berlin

Szerkesztó: Nóbik Attila

nobik@edpsy.u-szeged.hu

Olvasószerkesztố: Garai Imre

Technikai szerkesztốk: Balog Beáta, Fizel Natasa, Hársvölgyi Virág, Kiss Hajnal, Nagy Andrea, Pethő Villő, Nemeslaki Tas, Szeivolt Katalin, Szente Dorina

Kiadó: MTA Pedagógiai Tudományos Bizottsága Neveléstörténeti Albizottsága

Felelős kiadó:

Németh András, elnök

1075 Budapest, Kazinczy u. 23.

Terjesztési forma: online

ISSN 2415-9093 


\section{Pedagógiatörténeti Szemle}

2. évf. 1-2. sz.

2016

\section{Tanulmányok}

Vajda Zsuzsanna

Pszichometria Magyarországon a 20. század első felében

1.

Somogyvári Lajos

Oktatáspolitikai irányváltás a Szovjetunióban: egy iskolareform anatómiája (1958)

23.

Molnár-Kovács Zsófia

Az „Európa-kép” tartalmi vizsgálata a dualizmus kori középiskolai egyetemes történelemtankönyvekben

40.

Nagy Adrienn

A kereskedelmi iskoláink a 19. századi német és francia szakoktatás tükrében

61.

Pethő Villő - Gévayné Janurik Márta

A szegedi Városi Zeneiskola története 1935-1945 között

85. 


\title{
Pszichometria Magyarországon a 20. század elsó felében
}

\begin{abstract}
VAJDA ZsUZSANNA
Károli Gáspár Református Egyetem

A modern pszichológia megszületésében - ezt a pszichológushallgatók már a bevezető kurzusokon megtanulják - alapvető szerepet játszott, hogy a 19. század derekára létrejöttek a mentális funkciók mérésének elvi és gyakorlati lehetőségei. Az egyszerúbb megismerő funkciók (érzékelés, emlékezés) mellett az értelmi képességek jelentették az első komplex emberi sajátosságot, amelynek mérésével a kutatók kísérleteztek. A koponya- és agytérfogat- vizsgálatoktól nem túlságosan hosszú út vezetett az értelem teljesítmény alapú méréséig, amelynek legsikeresebb változata a mai módszerekre is hatást gyakorló Alfred Binet nevéhez füződik. Binet módszere gyorsan elterjedt a világ fejlettebbik felében, alig néhány éven belül Magyarországra is eljutott. Vajon tartogat-e érdekességeket a több, mint egy évszázaddal ezelőtt zajlott hazai adaptáció bemutatása a mai olvasónak? A válasz egyértelmúen igen, mégpedig több szempontból is.
\end{abstract}

A képességmérés történetének nyomon követése során láthatóvá válik a pszichológia önálló diszciplinává válásának egy fontos szakasza, az ezt követő, ma sem lezárult nyitott kérdésekkel együtt. A diszciplináris határok rögzítése különösen összetett volt a pedagógiával szemben, amelynek nemcsak a tárgya áll minden más embertudománynál közelebb a pszichológiáéhoz, hanem abban is rokon, hogy a képviselői - mint azt az intelligenciamérés meghonosítása körüli, később részletesen is ismertetendő viták is szemléltetik - szintén az „objektív tudomány" alapjaira szerették volna helyezni saját tevékenységüket.

A kor tudományfelfogása szempontjából nem kétséges, hogy az objektivitás egyik feltétele a mérhetőség. Csakhogy a képességek, mentális funkciók mérésére irányuló gyakorlati próbálkozások során egyértelmúen feltárulnak azok a nehézségek, amelyek a humán jelenségvilág kettős - környezeti és biológiai meghatározottságából fakadnak. A pszichológia korai képviselői érthető módon az információk befogadásával és feldolgozásával foglalkozó, teljesítményben is testet öltő kognitív képességek mérésére tesznek erőfeszítéseket. Ám amint többről van szó, mint a látás élességéről, vagy a reakció gyorsaságáról, már a meghatározás is nehéz. Mint látni fogjuk, a hazai és külföldi szakemberek változatos módon igyekeznek vizsgálat tárgyává tenni a gyerekek értelmi képességeit, és sokan később is szegényesnek érezték a pontozással nyert eredményeket. Fontosabbnak tartották a mérés során felfedezett tartalmi jellegzetességeket a 
gondolkodásban, amelyek mind a mai napig kívül maradnak a pszichológia látókörén.

A képességméréssel, illetve a Binet-próba meghonosításával kapcsolatos hazai erőfeszítések kapcsán megismerhetjük a korabeli nemzetközi tudományos közélet múködését. Tanulságos, hogy ezekben az évtizedekben, a világháborúk által előidézett nagy gazdasági-politikai átrendeződések előtt a mainál jóval intenzívebb kommunikáció zajlik a különböző országok, földrészek kutatói között. A párbeszédben részt vesznek a hazai szakemberek is, akik folyamatosan figyelemmel kísérik a nemzetközi tudományos élet fontosabb eseményeit. Magyarország ekkor egy európai középhatalom, az Osztrák-Magyar Monarchia egyik alkotó állama, amelyben intenzív a kapcsolattartás a központok között. A fontosabb kutatói kapcsolatok a német-osztrák központok között alakulnak ki: így például a szaksajtó beszámolói szerint a képességmérés alapjainak lerakásában fontos szerepet játszó William Stern az első világháborút megelőzően többször is jár Magyarországon. 1914-ben nagy hatású előadást tartott a Pedagógiai Szemináriumban. ${ }^{1}$ Éltes Mátyás pályája kezdetén Svájcban, Ausztriában és Németországban tanulmányozza a gyógypedagógiai oktatást (Gordosné, 1991). Nagy László rendszeresen tájékoztatja a hazai közönséget a Németországban zajló szakmai vitákról (Nagy, 1906). A nemzetközi tudományos közéletbe való bekapcsolódást elősegíti, hogy a népesség jelentős része, különösen az értelmiség, kétnyelvû, így az Európában legnagyobb, német nyelvi közösség része. Ugyanakkor egyre többen figyelnek az ebben az időben még szintén intenzív német kapcsolatokat ápoló, ám saját szemléletüket létrehozó amerikai szakemberek kezdeményezéseire.

A mérések konkrét lebonyolításának ismertetése ezen túl bepillantást enged az értelmi képességek eredetével, formálhatóságával kapcsolatos felfogásba, a mindennapi élet és múveltség néhány korabeli jellegzetességébe.

\section{Pszichológia És Pedagógia MagyarorszÁgon a 20. szÁzad KEZDETÉN}

A pedagógia és a pszichológia diszciplináris határainak kialakulása szempontjából feltétlenül említésre méltó körülmény a mindkettőt ${ }^{2}$ magában foglaló gyermektanulmányi szemlélet térhódítása a 19. század kezdetétől a 20. század derekáig. A gyermektanulmányozás eredetéről, megjelenéséről, tárgyáról több féle interpretációt olvashatunk, de az nem kétséges, hogy rendkívül népszerü, részben tudományos, részben a gyerekek különleges sajátosságaira, ezek megismerésére és tekintetbe vételére felhívó közéleti mozgalom volt.

A mai neveléstörténeti munkák általában Stanley Hall-nak tulajdonítják a gyermektanulmányi mozgalom elindítását. Más álláspontot képvisel a ha-

\footnotetext{
${ }^{1}$ Néptanítók Lapja, 1914. 4. sz.

${ }^{2}$ Legalábbis a pszichológia gyerekkori fejlődéssel foglalkozó területeit.
} 
zai gyermektanulmányi mozgalom történetét tanulmányozó Deák Gábor, aki szélesebben értelmezve a gyermektanulmányi szemléletet - Meumann-nak és Claparede-nek tulajdonít döntő szerepet. Deák azonban ebbe a körbe von más, a gyerekkori fejlődéssel kapcsolatos munkákat is (Deák, 2000). Ez azért félrevezető némileg, mert a gyermektanulmányi szemlélet az amerikai hagyományoknak megfelelően a tudományos megismerés természettudományos módszereit, a mérés és a kísérlet alkalmazását tartja a leginkább megfelelőnek, míg hazai képviselői közül többen is - köztük a gyermektanulmány legjelentősebb képviselőjének tekintett Nagy László - nem feltétlen támogatója a pozitivista szemléletnek.

Nagy László 1906-ban megjelent tanulmányában arra hívja fel a figyelmet, hogy a gyermekkori sajátosságok vizsgálata tekintetében eltérés van az amerikai és a német szakemberek szemlélete között. Az amerikaiak szerint a „gyermek, mint egész" a vizsgálat tárgya, ide értve az anatómiát, a történelmi és néprajzi sajátosságokat, a "testi és lelki erők egymásra hatását”, míg a német kutatók az anatómia, az élettan, a testi fejlődés, az idegrendszeri zavarok, a történelmi és néprajzi vonatkozások kutatását átengedik az illető tudományok búvárainak. Nagy álláspontja szerint a gyermektanulmány az amerikai szemlélet elnevezése, míg a németek megközelítése inkább gyermeklélektanként aposztrofálható. Az „adatgyújtés” - empírikus módszerek alkalmazása - tekintetében ugyanakkor az amerikaiak szigorúbbak, mint a németek (Nagy, 1907. 8. o.). Bár Nagy szerint a korábbi hazai szerzők, Donner és Pethes a német irányban indultak el, az általa alapított társaság és a gyermekekkel kapcsolatos pszichológiai jellegú vizsgálatok továbbra is diszciplináktól független gyermektanulmányozásnak minősülnek a szaklapokban.

Bár a hazai szakemberek többször is aggodalmukat fejezték ki azzal kapcsolatban, hogy Magyarország késik a neveléshez kapcsolódó tudományok meghonosításával (pl. Donner, 1899), a tények szerint ez a lemaradás nem túl jelentős. Szabolcs Éva (2002) tanulmányában a gyermektanulmányi nézőpont hazai megjelenését a Kolozsvárott az 1880-90-es években tevékenykedő Felméri Lajosnak tulajdonítja. Hasonlóan vélekedik Pukánszky Béla (2001, 430. o.), szó szerint idézve Felméri álláspontját, amely szerint a nevelőknek alapos pszichológiai ismeretekkel kell rendelkezniük. Ez az időszak lényegében egybeesik a gyermektanulmányi szemlélet német és amerikai térhódításával. A XX. század fordulóját és első évtizedeit rendkívül élénk szakmai közélet jellemezte a hazai pedagógiában: szaklapok, folyóiratok egész sora jelenik meg (Deák, 2000).

A neveléstudományi diskurzusok jelentős része A Gyermek, ill. A Néptanítók Lapja címú periodikákban zajlik, a nemzetközi közélet eseményeiről a hazai szakemberek egyebek között A Jövő Útjain címú havilapból tájékozódhatnak. Ez utóbbi egy befolyásos európai reformpedagógiai mozgalom, az Új Nevelés Lígája folyóirata, amelyben a hazai pszichoanalitikusok is publikálnak (Vaja, 1995). A hazai gyermektanulmányt főurak támogatták: az 1903-ban Nagy László kezdeményezésére megalakult Gyermektanulmányi társaság elnöke Teleki Sándor 
gróf volt (Gál, 2012). A Néptanítók lapja 1906-ban megjelent tudósítása ${ }^{3}$ szerint Teleki, „az újonnan megalakult Gyermektanulmányi Társaság elnöke, a közmúvelődés és a közoktatás ügyeinek lelkes barátja" tudományos estélyt rendezett, ahova arisztokrata hölgyek - például Tisza Istvánné és Károlyi Istvánné - valamint az ismertebb szakemberek - Nagy László, Ranschburg Pál - is hivatalosak voltak. Az estélyen gróf Teleki ismertette a gyermektanulmány ügyének aktuális hazai állapotát és az újabb nevelési irányokat. Figyelemre méltó, hogy a tudományt pártoló fóúr a természettudományos szemléletet tekinti a modern neveléskutatás alapjának. Ranschburg Pál előadását az ismertetés szerint a közönség feszült figyelemmel hallgatta, ezt követően a kérdésről élénk eszmecsere alakult ki.

A képességmérés megfelelő módszerének kidolgozása nemcsak tudományos cél volt, hanem gyakorlati igény is. A 19-20. század fordulójára a tankötelezettségnek Magyarországon is egyre szélesebb körben sikerül érvényt szerezni. Már az 1848-as szabadságharcnak is fontos törekvései közé tartozott a közoktatás, nem utolsó sorban a magyar nyelven való múvelődés támogatása érdekében. ${ }^{4}$ Az iskolai tanulás általánossá válása más országokéhoz hasonlóan a hazai oktatáspolitikát is szembesítette azzal a ténnyel, hogy a gyerekek bizonyos százaléka nem képes eleget tenni a követelményeknek. Az 1868-as törvény szerint a „,testileg, vagy szellemileg gyenge gyermekeket" a tisztiorvos felmenthette az iskolalátogatás kötelezettsége alól, és nem kellett iskolába járniuk a „taníthatatlanul tompa elméjü" gyermekeknek sem. A szakértelmiség jelentős része számára azonban nem volt elfogadható, hogy a gyengébb képességú gyerekek teljes mértékben oktatás nélkül maradjanak, annál is kevésbé, mivel nyilvánvalóan jelentős képezhetőségi különbségek voltak közöttük. A 19. század végén német mintára létrejönnek a különleges, „kisegítő” iskolák, 1907-ben pedig megnyitja kapuit a később fogalommá vált Mosonyi utcai kisegítő iskola a Ranschburg Pál irányította „Gyógypedagógiai és Pszichológiai Magyar Királyi Laboratórium”- a mai pszichológia és gyógypedagógia bölcsője - szomszédságában.

Fennállt azonban a probléma: az enyhén fogyatékos gyerekek csoportja jelentôs átfedést mutatott (ahogyan ma is) a szociálisan hátrányos helyzetúek csoportjával. A szakemberek abban reménykedtek, hogy a képességmérés segítségével objektíven elkülöníthetők lesznek a környezeti okokból, szegénység, „ingerszegény környezet” miatt lemaradó gyerekek a vélhetően szervi eredetú, kevésbé fejleszthető „valódi” fogyatékosoktól.

\footnotetext{
${ }^{3}$ A gyermektanulmány ügye egy fơúri estélyen. Néptanítók lapja, 1906. 3. 15. 16. oldal.

${ }^{4}$ Bár 1848 után az oktatásügy átmenetileg ismét osztrák irányítás alá került, a kiegyezés után egy évvel megszületett a Népoktatási Törvény, amely 6- 15 éves korig kötelezóvé tette az iskolát, amely kezdetben csak a legszegényebbek, majd 1908-tól mindenki számára ingyenes volt. A törvény hatására az iskolába járó 6-12 éves gyerekek aránya a kiegyezéskori mintegy 50, után 1896-ban 73, 1913-ban pedig már az adott korosztály 93\%-a. A huszadik század első évtizedeire az írástudatlanság jelentősen csökken Magyarországon: míg 1890-ben az analfabéták aránya még közel 40\%, 1920-ra az arányuk már csak 10\% (Mészáros, Németh és Pukánszky, 1999).
} 


\section{Az INTELLIGENCIAMÉRÉS SZÜLETÉSE}

Az értelmi képességek vizsgálatának szükségessége tehát a „levegőben volt”, a sokféle próbálkozás azonban nem vitt közelebb a pontos definícióhoz. A jelek szerint a képességmérés igénye először az elmekórtanban merült fel, úttörői közé tartozott a modern elmekórtan egyik alapítója, Kraepelin is. (Kun és Szegedi, 1978). A Binet-Simon teszt hazai adaptálásában is úttörő szerepet betöltő Nagy László 1912-ban keletkezett tanulmánya is megemlíti, hogy az értelmesség feladatok segítségével történő vizsgálata korábban az elmekórtani klinikák gyakorlata volt, a "gyengeelméjûség” azonosítása érdekében. Az elmegyógyászok szerint az értelmi képességek főbb kategóriái az „észrevétel, felfogás, figyelem, emlékezet, az ítélő-kombináló képesség” volt (Nagy, 1912., 89.o.), ezeknek megfelelően intéztek kérdéseket a betegekhez. Az elmekórtanban alkalmazott feladatokat azonban nem lehetett pedagógiai célokra felhasználni. Nem bizonyult használatónak a többek között Galton által szorgalmazott koponyamérés, a kraniometria sem (Gould, 1999). ${ }^{5}$

Pethes János, az egyik első hazai gyermeklélektani tárgyú, 1901-ben megjelent könyv szerzője szerint a "gyermekmegfigyelés" terén Stanley Hall-é a vezérszerep, aki a laboratóriumi vizsgálatok meghonosításával, előadásaival lelkesíto, sőt „gyújtó" hatással volt a szakemberekre. Ugyanakkor megemlíti, hogy Németországban már korábban is zajlottak kísérletek, például Jénában, ahol egy Stoy 6 nevú pedagógus már néhány évtizeddel korábban végzett statisztikai adatgyújtést a gyerekek képességeinek vizsgálatára. Pethes aggódik, hogy a hazai tudomány el van maradva e fontos kezdeményezések tekintetében (Pethes, 1901).

Eperjessy István 1906-ban született összefoglalójában arról számol be, hogy a 19. század utolsó harmadában több európai, elsősorban német városban zajlott a gyerekek „képzeteinek” a vizsgálata. A berlini kutató, Bartholomäi ${ }^{7}$ arra az akkoriban nem különösebben meglepő megállapításra jutott, hogy a falusi és a város gyerekek ismeretvilága és szókincse nagy mértékben eltér. Tanítóik arra panaszkodtak - idézi Eperjessy - hogy a gyerekek nem ismerik iskolájuk közvetlen környezetét sem, csak a mozgó tárgyak érdeklik őket, a „nyugvó tárgyakat” nem figyelik meg. Berthold Hartman ${ }^{8}$ Annabergben végzett

\footnotetext{
${ }^{5}$ Alfred Binet a szuggesztibilitásról szóló írásában megemlíti, hogy ő is próbálkozott a koponyaméret és az értelmi képességek közötti összefüggés igazolásával, de nem járt sikerrel. Binet a kutatókat nem mindig jellemző kritikus önreflexiója folytán - felfigyelt rá, hogy maga sem elfogulatlan, amikor a mérést végzi. Észreveszi, hogy a feladataikat jól teljesítő gyerekek fejkörfogatát hajlamos nagyobbnak, a gyengébben teljesítőkét kisebbnek mérni. (Többek között ezért jut arra az elhatározásra, hogy más módszerhez kell folyamodni.) (Binet, 1900).

${ }^{6}$ Karl Wolkmar Stoy, 1815-1885, német pedagógus, Herbart pedagógiai elveinek népszerúsítője.

${ }^{7}$ Friedrich Bartholomäi (1817-1878) német herbartiánus pedagógus, Johann Friedrich Herbart követője, az ún. „Jénai Pedagógiai Szeminárium” tagja a jénai egyetemen. Szakmódszertani múveket írt matematikából, geometriából és természettanból.

${ }^{8}$ Berthold Hartmann herbartiánus pedagógus, a 19. század végén tevékenykedett. Matematika-
} 
felmérése során, amely szintén szerepel Eperjessy beszámolójában, több száz kérdés segítségével vizsgálták első- és második osztályos gyerekek ismereteit. A gyerekeknek csak egy töredéke ismerte az órát, az évszakokat valamivel többen, de a teljes sokaságnak mindössze egy ötöde, a hét napjait az 500 gyerek közül mindössze 146 tudta felsorolni. Gyenge volt a gyerekek matematikai tudásának átlaga is.

A Németországban végzett vizsgálatok alátámasztották, hogy a szülők foglalkozása és iskolázottsága nagy hatással van a gyerekek tájékozottságára, értelmi képességeire. Eperjessy azonban arra hívja fel a figyelmet, hogy az ismertetett vizsgálatok nem voltak hitelesek, mivel csoportosan végezték őket, a gyerekek nem dolgoztak önállóan, hanem egymást figyelték. Azt sem találja megfelelő megoldásnak, hogy a vizsgálatokat a gyerekek tanárai végezték.

Eperjessy idézett munkája szerint Stanley Hall 1880-ban 134 kérdéssel vizsgálta 6-7 éves gyerekek „képzettartalmát” a berlini kutató, Bartholomäi módszere alapján. ${ }^{9}$ Hall tapasztalatai szerint a lányok képzettartalma felületesebb volt, mint a fiúké, beszélő-számolóképességük is gyengébb. A gyerekek 14\%-a nem tudta, hány éves. A fiúk azt tudták inkább, hogy mit nem szabad, a lányok, hogy mit nem illik. Téves képzeteik voltak a mennydörgésről - Hall egyik beszámolója szerint azt hitték, hogy ilyenkor az angyalok a mennyországban kugliznak.

Nagy László (1912) Ebbinghaust nevezi meg, mint a pszichometria gyerekkori alkalmazásának úttörőjét. Módszere a kombináló módszer volt - például olyan szöveget adott a tanulóknak, amelyből szótagok, vagy egész szavak kimaradtak, ezeket a vizsgált gyerekeknek pótolni kellett. Ebbinghaus pontszámok segítségével rangsorolta a teljesítményeket. Nagy megemlíti, hogy az angol Spearman, a "g faktor" fogalmának megalkotója szintén pontozta a gyerekek teljesítményét az általa kidolgozott feladatokban, majd a pontszámok alapján képzett csoportokat a pedagógusok rangsorával hasonlította össze. Ha a kétféle sorrend között nagy volt a különbség, akkor módosította a feladatokat, ha viszont közel voltak egymáshoz, akkor érvényesnek tartotta az eredményt.

Spearman módszerének az volt a legfőbb hibája - véli Nagy -, hogy a gyerekek teljesítményét az adott alkalmi csoporton belül vizsgálta, nem volt általános minta, amihez a teljesítményeket viszonyították volna. Lendületet adott a gyerekek vizsgálatának, hogy az egyetemeken, különösen Amerikában, egyre több helyen végeztek lélektani kísérleteket - ezek nyomán keletkeztek a próbák, avagy angol megnevezésük szerint tesztek. Ezekben azonban az intelligencia vizsgálata nem mint cél, hanem mint mellékes eredmény szerepelt - összegzi Nagy.

módszertani múvek szerzője, a gyermeki gondolkodás sajátosságairól a „gondolatkörökről” (Gedankenkreis) is publikált.

${ }^{9} \mathrm{Az}$ itt idézett szerző́k tanúsága szerint legalábbis pontatlan az a Gál Anikó (2012) tanulmányában szereplő állítás, mintha a gyermekek tanulmányozásának kezdeményezője Stanley Hall lett volna. 


\section{HAZAi KÍSÉRLETEK}

Német, amerikai és francia kollégáikhoz hasonlóan a magyar szakemberek is kísérleteztek gyermekek képességeinek vizsgálatával és hasonló nehézségekkel szembesültek. Eperjessy már idézett cikkében (Eperjessy, 1906) beszámol róla, hogy Éltes Mátyás és Ranschburg Pál 6-7 éves, iskolakezdő gyermekeket vizsgáltak egy gyermekek számára készült ismeretterjesztő munka, a „Mindentudó képeskönyv" közel 1000 színes ábrájának segítségével. A gyerekeknek meg kellett mondani a képek neveit, a fel kellett sorolni a részleteket. A teljesítmények nagy eltéréseket mutattak: a legjobb válaszoló 150 főnévből 130-at ismert fel, a leggyengébb 50-et. Maga Eperjessy 1904-ben 20 hat éves gyermeket vizsgált szintén az említett képeskönyv segítségével egy kültelki iskolában. A gyerekek többsége napszámosok, szegény iparosok gyermeke volt. Itt is erősen érzékelhető volt a társadalmi háttér hatása: egy tanító gyermeke $60 \%$-ot felismert a képeskönyvben ábrázolt tárgyak közül, míg a napszámos gyermekek átlagosan csak 17\%-et. Gyakran csacskaságokat válaszoltak, a papagájt például cédulahúzó madárként jellemezték, azt hitték, hogy az elefánt Törökországban élt és volt, aki nem ismerte fel Petőfi Sándor szobrát. Akárcsak a német vizsgálatok, a hazai kutatásokról szóló beszámolók is tükrözik, hogy a tankötelezettség kezdetén, a modern tömegkommunikációs eszközök megjelenése előtt és feltehetően a nagyon jelentős szociális különbségek hatására a mainál (is) jóval nagyobb volt az eltérés a különböző hátterú gyerekek tudása, ismeretei között.

Egy másik esetben Éltes és Ranschburg egy 7 éves, „mérsékelten gyengeelméjû kislány szó- és képzetkincsét" is megpróbálta felmérni, ugyancsak a Mindentudó Képeskönyv segítségével. A lányka "gyengeelméjûsége” elsősorban a számolási nehézségekben nyilvánult meg. Eperjessy egy 4 éves, ép értelmú fiú teljes szókincsének feltérképezésére tett kísérletet: napokat töltött a társaságában, és minden szavát feljegyezte. Megfigyelései szerint a kisfiú 6698 szót használt beszéd közben. Az anyag feldolgozása negyedévi fárasztó munkába került - jegyezte meg.

Ranschburg Pál nem tartotta meggyőzőnek a felmérések eredményeit - írja Eperjessy - ezért felkérte a gyermektanulmányi társaság kebelében alakult Pedológiai Bizottságot a vizsgálat további folytatására. Ebben szintén a „Mindentudó képeskönyvet” használták, a felmérést tanítók végezték. Kikérdezték az iskolakezdő gyermekeket otthoni körülményeikről, saját tevékenységükről, megkísérelték felmérni verbalitásukat, a színek, számok ismeretét, vizsgálták a gyerekek fizikai adottságait is. A beszámoló szerint ugyan a változó létszámú gyerekcsoportok teljesítményátlaga jobb volt egy német vizsgálatban ismertetett annabergi csoporténál, ám a teljesítményükben rendkívül nagy volt a szórás: a legjobb teljesítmény 150 főnévből 130 felismerése volt, a leggyengébbek azonban csak 50-et ismertek fel. A színek ismeretét 80 gyereknél vizsgálták, 10 alapszínt kellett felismerniük. Az átlag 7 szín felismerése volt, de a volt, aki csak hármat 
tudtak azonosítani. 210 tanulónak számokat kellett felismernie: ezt a gyerekek 86\%-a sikerrel teljesítette. A szék, olló, kanál, pipa, kutya jelentését a megkérdezett gyerekek 99\%-a ismerte, de például a fürdőkád, a szarvas, vagy a tyúk jelentését már csak $54 \%$, és $25 \%$-nál is kevesebben voltak képesek azonosítani a juh, táviró, drót, sakk, tulipán, gramofon stb. tárgyakat. Különösen szegényes volt azoknak a gyerekeknek az ismeretvilága, akik nem jártak óvodába - úgy túnik, a szülőknek nincs ideje a gyermekkel foglalkozni - állapította meg Eperjessy. Javaslatokat is megfogalmazott az értelmesség elősegítésére: ki kell vinni a gyermeket a szabad természetbe, és „minden tanulságosra” fel kell hívni a figyelmét, mert csak azok az ismeretek tartósak, amelyeket a közvetlen tapasztalat útján szerzünk. Nem helyes csupán száraz ismeretközlésre szorítkozni, gyakorlati példákkal kell megvilágítani, amit meg szeretnénk tanítani. Ugyanez vonatkozik az etikai szabályokra - legyenek képesek átélni, milyen az, ha bezárnak egy madarat a kalitkába.

A fent idézett eredmények világosan jelzik - összegzte mondanivalóját Eperjessy - hogy a tanítóknak ismerni kell a gyerekek ismeretvilágát. Aggasztotta, hogy a városi gyermekek „képzettartalma” túl nagy terjedelmú - az utóbbival kapcsolatban felmerült annak kockázata, hogy a „rohamosan összetorlódó gondolatképek nem homályosítják-e el egymást?” (Eperjessy, 1906. 134. o.).

\section{Berkovics RenÉ vizsgálatai}

A képességmérésekkel kapcsolatos jelentôsebb próbálkozások közé tartozott Berkovics René nagyváradi orvosé, amelyet „esettanulmányként” részletesen is ismertetünk. Berkovics (Berkovics, 1913). a hazai szerzők közül elsőként használta az intelligencia kifejezést, ám megállapította, hogy mindenki mást ért alatta. Ez nem meglepő - szögezi le - hiszen aligha rendelkezünk a normális intelligencia pontos kritériumával, amelynek alapján úgy mérhetnénk az értelmességet, mint a méterrúddal a hosszúságot.

Berkovits egy 66 kérdésből álló sorozatot állított össze, amelyet az orvosi gyakorlatban és az oktatásban tervezett alkalmazni. Azokat tekintette normál intelligenciájúaknak, akik az általa kidolgozott feladatok több, mint a 90\%-át meg tudták oldani. A tesztet felnőttek számára készítette, ezért üdvözölte Binet és Simon próbálkozását az intelligencia „lépcsőzetes” mértékének meghatározására. Fontos lenne - jegyezte meg - hogy a gyerekek intelligenciáját meg tudjuk becsülni, ehhez azonban arra van szükség, hogy ismerjük életkori sajátosságaikat. Vannak gyerekek, akik az „ú.n. játékos korban” értelmesnek látszanak, de már az elemi oktatás elsô lépéseinél megakadnak. Az orvosi vizsgálat nem talál szembeötlő defektusokat, az otthoni miliő sincs a gyerek ártalmára, mégis elmarad a többitől. Ma már általános az a nézet, hogy az ilyen, gyengébb képességú gyerekeknek kisegítő iskolába kell járnia. Ennek érdekében objektív mércére van szükség - szögezte le -, mivel kételkedik benne, hogy a 
pedagógusok értékítéletei mindig helytállóak-e a gyerekek fogyatékosságával kapcsolatban. Ha erről egy vizsgálattal képet kaphatnánk, a gyerekeket számtalan kellemetlen helyzettől, a pedagógusokat pedig sok felesleges munkától kímélnénk meg - vélte.

Berkovics végül iskolakezdő gyerekek számára is kidolgoz egy feladatsort, amelyet a Binet-teszt életkori táblázatai szerint épít fel. A vizsgálatot nagy gonddal végezte: előzetesen több próba-mérést tartott, hogy a kikristályosodjon a megfelelő kérdezési mód, megismerje a gyerekek várható reakcióit. A minta összeállításához elemi iskolai tanítók segítségét kérte, így választottak ki 40 átlagos képességú 6-7, ill. 40 feltételezhetően enyhén fogyatékos 6-9 éves gyereket. (Az életkori eltérés abból adódott, hogy az enyhén értelmi fogyatékosok még 8-9 éves korukban is az első osztályba jártak).

A kérdések között szerepelt mindennapi tárgyak felismerése , az ezekre adott válaszok azonban félrevivőek voltak, hiszen jelentős különbség volt a gyerekek teljesítményében annak a függvényében, milyen volt a nevelői környezet. Más feladatok megoldása arra hívta fel a figyelmet, hogy gondolkodás vizsgálatánál a tartalmi szempontok sem elhanyagolhatóak. Így például, amikor a gyerekeknek példát kellett mondania négy, illetve kétlábú állatokra, Berkovits azt tapasztalta, hogy az enyhén értelmi fogyatékos gyerekek közül jóval kevesebben voltak, akik kétlábú állatot meg tudtak nevezni. Feltételezte, hogy számukra az „állat” képe - ma kognitív sémának neveznénk - elsősorban négylábú. Az 1911-ben első osztályba járók közül senki sem tudott választ adni a kérdésre, mennyibe kerül a zsemle. Berkovics magyarázata szerint a gazdag gyerekek soha nincsenek jelen vásárlásnál, a szegényeknek pedig nincs dolga pénzzel. Azt is csak a gyerekek töredéke tudta, hogy hívják az ország királyát, holott a Monarchia császára és Magyarország királya ekkor már több, mint fél évszázada Ferenc József volt. Az egyébként ép értelmúnek bizonyult gyerekeknek is csupán a háromnegyede tudta megfogalmazni, mi a különbség a szék és az asztal között. A színeket az ép értelmú hat évesek biztonsággal felismerték, az enyhén értelmi fogyatékosok azonban nem. ${ }^{10}$

Berkovits megállapítása szerint a tartalmi különbségek vizsgálata alkalmasabb lenne a fogyatékosok és az átlagot elérők elkülönítésére, mint maga a pontszám. Mint látni fogjuk, más, a képességméréssel foglalkozó hazai kutatók hasonló következtetésre jutottak, ám különböző okokból mégis szinte kizárólag a számszerú, tartalomtól független statisztikai alapú mérések terjedtek el a tudományban és a gyakorlatban.

\section{MiÉRT ÉPPEN BINET?}

Áttekintve a korabeli próbálkozásokat felmerül a kérdés: mi a magyarázata, hogy a sokféle hasonló kísérlet közül éppen Binet és Simon módszere vált elfogadottá

\footnotetext{
${ }^{10} \mathrm{Ma}$ a színek felismerése 3-4 éves kori sztenderd.
} 
és sok későbbi intelligenciateszt alapjává? Nagy László (1912) rávilágít az egyik legfontosabb okra: a teljesítmények és az életkor kapcsolatának felismerése által létrejött az a viszonyítási alap, amelynek hiánya megnehezítette a korábbi mérések értelmezését. A gyermekkori képességek felső határa, az a szint, amelytől fogva az idősebb gyermekek teljesítménye már nem javult jelentősen, elvileg elvezetett a felnőtti sztenderd rögzítéséhez.

Binet eljárásának másik, követendőnek bizonyult eljárása a feladatok változatos karaktere: Néhány példa Alfred Binet eredeti próbáiból (Éltes, 1914b. 9. o.)

3 év: Megmutatja orrát, szemét, száját, stb., két számot ismétel. Felsorolni egy kép személyeit, vagy tárgyait. Megmondani családnevét. A képen levő tárgyakat megnevezi, 6 szótagból álló mondatot ismétel.

4 év: Megmondani, hogy fiú, vagy lány-e. Megnevezi (megmutatja) a kulcsot, a kést, egy fillért stb, megismétel három számot. 5 és $6 \mathrm{~cm}$ hosszú vonalat összehasonlít.

5 év: Az egyformának látszó két 6 és 12 gr, továbbá 6 és 15 gr-os skatulyát összehasonlít, megmondja, melyik a nehezebb. Tíz szótagból álló mondatot elismétel, türelemjátékot megfejt. (Két téglalap közül az egyiket átlósan kettévágjuk és a gyermeknek össze kell úgy illesztenie, hogy téglalap legyen).

Könnyen belátható, hogy a feladatsor más, komplexebb értelmesség- definíciót sugall, mint az ismertetett német és hazai vizsgálatok. Az utóbbiak, mint arra korábban utaltunk, általában kiválasztottak valamilyen jól- rosszul definiált kognitív képességet: a „gyermek képzettartalmát”, a szókincset, a tájékozottságot, a számolási képességet stb. A Binet-próba ezzel szemben többféle képességet (emlékezet, logikai képesség) és a cselekvésben megnyilvánuló értelmességet is vizsgálja, az ezekben nyújtott teljesítmények átlagából alakul ki az értelmesség életkori kvóciense. Ebben követi a ma is a legalaposabbnak tekintett Wechsler-sorozat, amelynek első változatát a névadó kutató dolgozta ki az Egyesült Államokban az 1930-as években. Vagyis a Binet-próba latens intelligenciafogalma valóban nem egy-egy kognitív képesség színvonalát méri, hanem olyan képességet, amely eltérő karakterû feladatokban hasonló szinten jelen van - kimondatlanul előfeltételezve a Spearman által bevezetett "g" faktor létét (Pléh, 2000).

Fontos megjegyezni, hogy Binet nem értékeli túl az általa kidolgozott vizsgálatot: több írásában is kiemeli, hogy a módszere nem mindenható. A mérést nem végezheti bárki: „Nem kezelési módszer és a sietős orvosnak, ki az ápolókkal akarná alkalmaztatni, megjósoljuk, hogy meg fogja bánni." (Binet, 1916. 120. o.). Az eredményeket kommentálni és értelmezni szükséges - hívja fel a figyelmet. Álláspontja szerint a vizsgálat pontossága csak annyi, „amennyi a lelki jelenségekkel összefér; a képzettségi fokot nem lehet olyan pontosan megmérni, mint a test súlyát, vagy magasságát. A gyermek figyelme, emlékezete, lélekjelenléte, mind törékeny tulajdonságok, amelyek nem jelentkeznek mindig ugyanabban 
az állapotban; egyik nap tíz hibát ejt egy tollbamondásban, másnap húszat fog elkövetni ugyanolyan körülmények között. A vizsgálatnak tehát nem célja, nem is lehet célja kijegecesíteni egy gyermeket; a gyermek változó marad, mint a természete kívánja" (Binet, 1916. 34. o.).

Binet arra is nyomatékosan felhívja a figyelmet, hogy az iskolai balsikerek oka változó. Véleménye szerint legalább száz „szekundást' kell megvizsgálnunk, hogy felismerjük mindazokat az okokat, amelyek a gyengébb teljesítmény magyarázatául szolgálhatnak A felsorolt okok közé tartozik, hogy a család gyakran anyagi körülményei miatt nem múködik együtt kellőképpen az iskolával. Binet szerint a gyerekek külseje és viselkedése is elárulja, hogy le vannak maradva. Az összbenyomás - a testtartás, az arcszín és az arcvonások - elárulják, ki az, aki fogyatékossággal küzd. Binet fiziológiai nyomornak nevezi ezeknek a gyerekeknek az állapotát, amely társadalmi nyomorból ered. Meggyőződése szerint azonban az értelem „minden érzékenységi, érzelmi és akarati jelenségtől független” megismerő képesség (Binet, 1916. 111. o.). Fontosnak tartja kiemelni, hogy az értelem fejleszthető. A túlságosan nehéz feladat elkedvetlenít - szögezi le -, lehetőleg ne kívánjunk többet a gyerekektől, mint amire valóban képesek.

\section{A Binet-PRóbA HAZAi ADAPTÁciója}

A képességmérés rendszeres használatához szükséges hazai sztenderd kidolgozását végül a gyógypedagógia úttörője, Éltes Mátyás végezte el. ${ }^{11}$ Éltes gyakorló pedagógusként is foglalkozott a fogyatékos gyermekekkel, és tapasztalatai alapján feltétlenül szükségesnek látta olyan eszköz kidolgozását, amelynek segítségével objektíven és biztonságosan meg lehet húzni a határvonalat a normalitás és a fogyatékosság között. Binet-től eltérően úgy vélte, hogy a „gyengeelméjűségnek" nincsenek külső jelei. Előfordul ugyan, hogy a fogyatékosság valamilyen testi, vagy nyilvánvaló agyi rendellenességgel függ össze, de egyáltalán nem mindig. Gyakori, hogy a gyengeelméjû egyénen semmilyen kóros elváltozást nem találunk - írta (Éltes, 1902).

1914-ben a Magyar Gyermektanulmányi Társaság ülésén hangzott el Éltes beszámolója a Binet-teszt adaptációjáról. 1911-ben kezdte el Binet próbáit magyar nyelvre fordítani, Nagy László már meglévő fordításának felhasználásával és a gyöngetehetségû́ gyerekek kiválasztására alkalmazni. Csakhamar kiderült, hogy a próbák abban a sorrendben, ahogyan Binet alkalmazta, a hazai felhasználáshoz nem felelnek meg. Éltes szerint először az átlagos képességú gyerekek teljesítményéről kellett képet kapni, csak ennek alapján vizsgálhatók a lemaradást mutató gyerekek.

\footnotetext{
${ }^{11}$ Éltes pályája kezdetén német, osztrák és svájci intézetek egész sorát látogatta végig, mivel alaposan szeretett volna tájékozódni a fogyatékosság, vagy ahogyan akkor nevezték, a gyengeelméjúség megítélésének, kezelésének kérdéseiben. Csalódottan állapítja meg, hogy sem a gyengeelméjúség lényegére, sem annak általános érvénnyel bíró okaira nézve nem találkozott határozott állásfoglalással.
} 
Saját vizsgálatát budapesti, 8. kerületi iskolákban végezte, az 1911-es próbákkal. A nemzetközi tesztet alkalmazta, mert ekkori reményei szerint így a mi eredményeinket összevethetjük a „múvelt nemzetek gyermekein” végzett kutatások eredményeivel. Az intelligencia definíciójánál W. Stern definícióját fogadta el: az egyének általános képessége, amellyel a gondolkodását tudatosan új irányba fordítja, általános lelki alkalmazkodóképesség az élet új feladataival szemben. "Az intelligenciát magyarul értelmességnek nevezhetnénk és nem azonos a lángésszel, sem a talentummal, sem az iskolai tudással." - állapítja meg (Éltes, 1914. 258. o.).

A tesztet 40 3-5 és 178 6-12 éves gyerekekkel végezte Budapest munkások és az alsó középosztály által lakott kerületeiben. Elsősorban a német adaptáció eredményeire, Bobertag, Chotzen és Stern munkáira támaszkodott. Az új próbákat az említetteken kívül még 438 gyermeken próbálta ki. (Éltes, 1914; Gál, 2012). A német adaptálókhoz hasonlóan Éltes is szembesült azzal, hogy a hasonló korú magyar és a francia gyerekek nem ugyanazokat a feladatokat tudták megoldani. Mások a pénznemek, de a „francia gyermek lelkében bizonyos egyéni sajátosságok máskép alakulnak ki, mint a magyar gyermeknél" (Éltes, 1914. 259.) - írta. Néhány érdekes példa: a két háromszögből téglalap összeállítása az 5 éves francia gyerekek számára egyáltalán nem okozott gondot, a magyar ötéveseknek azonban csak 5\%-a, a hatévesek $48 \%$-a és még a hétéveseknek is csak $68 \%$-a oldotta meg. Hasonló eltérés volt a rombusz (korabeli szóval dülény) másolásánál: Binet szerint ez 6 éves korúaknak való feladat, ám a magyar 6 éveseknek csak 28\%-a, a 7 éveseknek is csak a 64\%-a birkózott meg vele. A fiúk ebben a feladatban sokkal jobbak voltak, mint a lányok: a 7 évesek $85 \%$-a, az ugyanilyen korú lányoknak azonban csak a $42 \%$-a volt képes a rombusz lerajzolására. Éltes több területen is tapasztalta, hogy a fiúk és a lányok teljesítménye eltér, voltak próbák, amelyekben a fiúk és voltak, amelyekben a lányok bizonyultak ügyesebbnek. A fiúk és a lányok teljesítményében mutatkozó különbség oka feltehetően összefüggött az iskolázottság jellegzetességeivel (a tankötelezettség nem egyformán terjedt ki a fiúkra és a lányokra és nem is egységes tanterv szerint tanultak), mivel a mai mérések szerint nincsenek szignifikáns különbségek a fiúk és a lányok teljesítménye között (Vajda, 2017).

A magyar és a francia gyerekek eredményei közötti különbségek miatt az átlagok egészen máshol helyezkedtek volna el, ezért Éltes úgy alakította át a Binet-Simon-féle tesztet, hogy az jobban illeszkedjen az itthoni gyerekek teljesítményeihez. Eközben igyekezett kiküszöbölni Binet néhány pontatlanságát. Például Binet nem határozta meg egyértelmúen, hogy a nem teljesítők milyen arányánál kell az adott feladatot az idősebbekéhez sorolni. Éltes ezt az arányt az adott korosztály 55\%-ában állapította meg. Ugyanakkor nem követte Bobertagot, aki teljesen átalakította Binet 10-15 évesek számára javasolt próbáit. Éltes verziójában a pontozás súlyozása is alakította az eredményt, mivel álláspontja szerint 11-15 éves korban az értelmi fejlődés lelassul. 
A teszt adaptált formájával végzett mérés szerint az ép magyar gyermekek nagy átlagának értelmi fejlettsége megfelelt az életkoruknak: a 302 vizsgált gyerekből 203 esetében az intelligenciakor(IK) és az életkor (ÉK) közel volt egymáshoz. Ez azért fontos - szögezte le Éltes - mert, ha a gyerek teljesítménye nem felel meg a korának, akkor a pedagógus nem tud objektíven értékelni. A vizsgálat lehetősége befolyásolja az oktatáspolitikai döntéseket is, mivel az eredmények alapján a gyerekek kb. 20\%-a 6 éves korában még nem éri el az életkornak megfelelő értelmességi fokot. Az ő esetükben a beiskolázást későbbre kellene halasztani. A másik $20 \%$ a zseniális gyerekek, ezekről ugyanúgy kellene gondoskodni, mint a vakokról és siketekről - vélte. A 11-12 éves korosztály feltûnően gyengének bizonyult a próbákban: Éltes szerint az ok az volt, hogy a felmérést elemi iskolásokkal végezte, a jobb képességú gyerekek viszont általában 10 éves koruk után középiskolában folytatták a tanulmányaikat. Kiegészítésképpen egy alsó fokú középiskolában is elvégezte a mérést, itt valamivel kedvezőbbek voltak az eredmények (Éltes, 1914).

\section{VITA A HAZAI ADAPTÁCIÓ EREDMÉNYEI KÖRÜL}

Éltes beszámolója után vita alakult ki az ülésen. A hozzászólók egy része határozottan ellenezte az eredeti, Binet-ék által kidolgozott próbák megváltoztatását, véleményük szerint a tesztet eredeti formájában kellett volna alkalmazni. A változtatásokkal - érveltek a hozzászólók - elvész a nemzetközi összehasonlítás lehetősége. Révész Géza (ekkor a Pedagógiai Szeminárium keretében múködő Lélektani Laboratórium igazgatója) is vitathatónak tartotta az egyes feladatok más korosztályokhoz történő átültetését. Véleménye szerint, ha komoly eltérések vannak a különböző országok gyerekei között, akkor a teszt szorul korrekcióra. Amellett érvelt, hogy az intelligenciatesztet univerzálissá kell alakítani.

Csakhogy számos jel utalt rá: a Binet-Simon-tesztben nyújtott teljesítmények nem feltétlenül kapcsolhatók össze az értelmi fejlődés univerzális sajátosságaival, vélte Révész Géza tanítványa, névrokona, a szintén a Lélektani Laboratórium munkatársaként tevékenykedő Révész Emil. Mint arról már szó esett, ő is végzett kísérleteket a Binet-Simon teszt hazai kipróbálására, mégpedig jóval nagyobb, 700 fős mintán. Vizsgálatában (amelynek dokumentumai nem lelhetőek fel) a 7 éves magyar gyerekek gyengébbek, a 8 évesek pedig jobbak voltak, mint a franciák. Révész Emil szerint a Binet-Simon-próbák általában túlságosan könnyứek voltak, és minden korosztálynál találkozhatunk olyan kérdésekkel, amelyek a változó tárgyi tudást vizsgálták, ezért a Binet-Simon-teszt nem alkalmas az általános értelmesség mérésére.

A vitát végül a nagy tekintélyú Nagy László döntötte el. Nem értett egyet az összes „múvelt nemzetre” kiterjedő egyetemes érvényú teszt alkalmazásával, helyeselte, hogy a próbákat Éltes a magyar gyerekek sajátosságaihoz igazította. Felhívja a figyelmet, hogy a Binet-Simon tesztnek elsősorban gyakorlati jelen- 
tősége van: például a beiskolázásnál vagy a fiatalkorúak búncselekményeinek jogi megítélésnél. Az átlagos, a gyengébb és a tehetséges gyerekek aránya az Éltes-próba alapján megfelelt a Binet-Simon, és a teszt német adaptálója, Bobertag vizsgálati eredményeinek, tehát a módszer jó. Mindemellett látható, hogy az eltérő környezetben nevelkedő - például a falusi és a városi - gyerekek teljesítménye nagyon különböző, ezért lehetséges, hogy a vizsgálatukat is eltérő módszerekkel kellene végezni.

A másik hozzászóló a szintén köztiszteletnek örvendő Ranschburg Pál volt. Szerinte érthető az igény olyan módszer kidolgozására, amely a tiszta intelligenciát vizsgálja, és amely fundamentális és abszolút, ám látni kell, hogy erre még nincs lehetőség. A „fundamentális” vagyis univerzális alaptulajdonságok mérésére a pszichológia egyelőre nem rendelkezik eszközökkel - vélte. "Az egész pszichológia összes kérdéseinek minden apró tényrészletükben vitán felül tisztázottaknak kellene lenniök", ehhez pedig - írta Ranschburg - az egész jelen század is kevés idő lesz. Ő is állást foglalt amellett, hogy az intelligenciavizsgálat gyakorlati kérdés. Megnyugtatónak tartotta, hogy a Binet-Simon-teszt nem az iskolai teljesítményt vizsgálja, hanem attól elkülöníthető képességet, és megfelelőnek tartja, hogy a Binet-Simon teszt nem izolált, hanem összetett képességeket próbál mérni (Éltes, 1914. 269. o.).

Éltes válaszában szintén kiemelte, hogy Binet nem egyes képességeket akart vizsgálni, hanem a lelki képességek egész komplexumát, ezért a feladatok áthelyezése nem ellentétes a tesztalkotó szándékával. Binet maga sem ellenezte ezt az eljárást és mások is alkalmazták - hívja fel a figyelmet. Ha a feladatokat nem adaptáljuk a hazai gyerekek képességeihez, akkor éppen a végeredmény, az átlag lesz irreális, ami szintén lehetetlenné teszi a más nemzetek eredményeivel való összehasonlítást. Mivel Révész Emil azt is kifogásolta, hogy nem a jó képességú gyerekeket vizsgálta, elmondta, hogy ezúttal a „legnagyobb számú" az átlagot képviselő szociális néposztály gyermekein akarta kipróbálni a tesztet. Bizonyos benne hogy a Belvárosban a jó nevelésben-oktatásban részesült tehetséges gyerekek jobb eredményeket érnek el, mint az erdélyi havasok pásztorgyermekei. Ám meggyőződése szerint a különbségek 8-9 éves korban eltûnnek, vagy minimálisra redukálódnak: az iskola vagy az élet megszünteti őket $^{12}$ (Éltes, 1914).

\footnotetext{
12 Nagy (1912) egy korábbi tanulmányában is kifejti, hogy a múvelt szülők és a „köznép” gyermekei közötti különbség elsősorban kisebb korban, 3-6 éves korban mutatkozik, ekkor a gyermekek fizikai életkora mögött az értelmi képességei 2-3 évvel visszamaradnak, ám a kedvezó társadalmi helyzetú, múvelt szülők gyermekeinek értelmi előnye a nem múvelt szülők gyermekei fölött fokozatosan csökken. Ebből arra lehet következtetni, hogy a jobb módú és múveltebb szülők gyerekeinek „jjobb kilátásai az életben való boldogulásra nem a tehetségükön alapul, hanem azon, hogy könnyebben bejutnak magasabb iskolákba". Sajnos, nem tudjuk, hogy Nagy vajon konkrét adatokból, vagy egyedi tapasztalatokból szûrte-e le a véleményét, pedig nem kis jelentősége volna, ha lehetőség volna a korabeli és a későbbi, iskolázottsággal kapcsolatos társadalmi mobilitás vizsgálatára.
} 


\section{Az INTELLIGENCIAMÉRÉS ALKALMAZÁSA A BEISKOLÁZÁSNÁL}

A Binet-Simon teszt adaptációja tehát valóban segítséget jelentett a különleges oktatást igénylő, gyengébb képességû gyermekek azonosításában. ${ }^{13}$ Éltes azonban a mérés hasznosságának hangsúlyozása mellett arra hívja fel a figyelmet, hogy „,a módszer a lélektani kísérletezésben nagy jártasságot, finom megfigyelőképességet és szigorú önbírálatot kíván a vizsgálótól” (Éltes, 1916. 317. o.). A világháború megrázkódtatásai közepette sem hagy fel törekvésével, hogy a pedagógusokat meggyőzze az intelligenciamérés fontosságáról. A gyógypedagógia, a gyermekbíróságok tevékenysége, a javító nevelés a gyermek alapos megismerésén kell, hogy alapuljon - hívja fel a figyelmet. Ezen túl az intelligenciamérés segítségével elkerülhető, hogy olyan gyerekek kerüljenek kisegítő iskolába, akiknek az elmaradása látszólagos és nincs szükségük különleges bánásmódra. Sem a társadalomnak, sem a gyermeknek nem érdeke hogy az ilyen gyerekek különleges iskolába járjanak. Ugyanakkor azt is fontosnak tartja, hogy a gyerekek megítélése ne csak az intelligenciamérés alapján történjék, hanem folyamatos megfigyelések alapján szülessenek a gyerekek sorsát érintő fontosabb döntések. Javaslatára a kisegítő iskolák tanítói és orvosai ún. minősítő lapot vezetnek, amelyen folyamatosan feljegyzéseket készítenek a "gyönge tehetségú" tanulókról. Az intelligencia mérése mellett alapos anamnézist vesznek fel, tájékozódnak a gyerekek családi életéről, szociális hátteréről (Éltes, 1915; Gál, 2012).

A képességméréssel foglalkozó szakemberek sikerének tudható be, hogy az 1921-es oktatási törvény kimondja a fogyatékos gyermekek tankötelezettségét. Beiskolázásukat ugyanakkor akadályozza, hogy nem jön létre a kisegítő iskolák országos hálózata, Budapesten kívül mindössze öt, a fogyatékos gyermekeket oktató iskola létesül. A szakemberek körében növekvő csalódottságot okoz, hogy az oktatási kormányzat elsősorban anyagi okokból hátráltatja újabb kisegítő iskolák létesítését (Éltes, 1928).

Igaz, már ebben az időben is vannak, akik nem értenek egyet a fogyatékos gyerekek külön oktatásával. Csillag Lipót 1918-ban megjelent cikkében arról ír, hogy egy fővárosi iskolában a szülők kezdeményezték a gyerekek képességek szerint osztályokban tanítását. Csillag ellenzi a szegregációt mind a tehetséges, mind a gyengébb képességú gyerekek esetében. Kiemeli az iskola nevelő funkcióját, amelybe beletartozik, hogy a különböző képességú gyerekek együttmúködjenek: a tehetségesek ne gúnyolják és vessék meg gyengébb társaikat, a gyengébbek pedig irigység helyett értékeljék és igyekezzenek utánozni a jobbakat. Nem jó, ha az iskolában el vannak különítve, hiszen az életben úgyis

\footnotetext{
${ }^{13}$ Bár kétségkívül ez volt az alkalmazók törekvése, nem állja meg a helyét Gál Anikó megjegyzése, amely szerint az adaptált Binet-próba alkalmas lett volna a szociális helyzetük, illetve idegrendszeri károsodásuk miatt lemaradók egyértelmú megkülönböztetésére. Az utóbbit gyakorlatilag lehetetlenné teszi, hogy a súlyos nyomor és nélkülözés az élet első éveiben hátráltatja az idegrendszer fejlődését és szervi szintú elváltozásokat is okozhat.
} 
találkozniuk kell. A tehetség egyébként is ritkán homogén: vannak gyerekek, akik bizonyos tárgyakban tehetségesek, másokban nem. Az értelmi fogyatékos gyermekeket álláspontja szerint csak átmenetileg szabad külön nevelni, lehetőleg vissza kell juttatni az egészségesek közé. Összességében tehát nagy hiba már az általános iskolában elkülöníteni a gyerekeket - az osztálynak együtt kell leküzdeni a nehézségeket - állapítja meg (Csillag, 1918).

Úgy tûnik, hogy a kisegítő iskolai rendszert Éltes sem találja minden szempontból megnyugtatónak: 1928-ban írott tanulmányában egy német modell átvételét javasolja, amelynek megfelelően a gyengébb képességú gyerekeket egy éven át normál tantervú, de kis létszámú osztályban tanították. Itt nem volt osztályzás, csak megfigyelték a gyerekek haladását, és csak ezt követően dőlt el, milyen iskolatípusba kerüljön. Így elkerülhető a „,szekunda”, a gyerek rossz osztályzattal való megszégyenítése (Éltes, 1928).

\section{PSZICHOMETRIA A HAZAI PSZICHOLÓGIÁBAN A KÉT VILÁGHÁBORÚ KÖZÖTT}

Miközben az Egyesült Államokban az intelligenciamérés a diadalútját járja olyan érzékeny politikai területekhez kapcsolódva, mint a bevándorlók szelekciója (Gould, 1999), a hazai szakembereket továbbra is intenzíven foglalkoztatják a pszichometria nyitott kérdései. Nem született meg az intelligencia egyértelmú definíciója, a kutatók minduntalan szembesülnek vele, hogy az értelmi képességek kvantifikálása távolról sem tükrözi sem a funkció összetettségét, sem az egyéni különbségeket. Maga Nagy László sem vált a képességmérés feltétel nélküli támogatójává. 1925-ben történő kényszernyugdíjazása után szerepet vállal a Pedagógia Szeminárium Lélektani Laboratóriumában, ahol új kategóriát dolgoznak ki a gyerekek értelmi képességeinek vizsgálatára: a pszichogrammát. Álláspontja szerint az utóbbi „nem lehet a lélektani tények száraz összefoglalása.... összeállítása nem lehet pusztán a pszichológiai tudás eredménye. Annak alkotó elemei között az intuíció is helyet kell hogy foglaljon. A jó pszichológusnak nemcsak tudósnak, hanem múvésznek is kell lennie." (Nagy, 1926. 98. o.).

Focher László és Szondi Lipót 1919-ben adják közre saját pszichometriai vizsgálatuk eredményeit, amelyek a mentális teljesítmények szociális meghatározottságára hívják fel a figyelmet. A vizsgált minta tagjai „falusi iskolát végzett egyének - normális iskolásgyermekek és legénységi állományú katonák". A szerzők megállapítják, hogy a koponyaméretek és a mentális teljesítmény között nincs összefüggés. Adataik szerint a falusi iskolát végzettek teljesítménye valamennyi feladatban nagyobb szórást mutat, mint a városiaké, emellett a városiak 100\% körüli teljesítményével szemben a falusiak gyakran csak 60-70\%-os teljesítményt érnek el. Megállapításaik szerint a szavakra való emlékezés és a huszas számkörben való számolás mutatja a legmagasabb korrelációt más teljesítmé- 
nyekkel, tehát ez a két próba alkalmas az intelligencia általános megítélésére. Az idősebb kor - állapítják meg - befolyásolja a százalékos eloszlást, a normalitás határán kívül eső kivételek ritkábbá válnak. (Focher és Szondy, 1919. 199.o)

Hosszabb tanulmányt szentel a tesztvizsgálatok értékelésének Hermann Imre is, akit a pszichoanalízis mellett egész pályáján intenzíven foglalkoztatott a racionális gondolkodás, az értelmi képességek kérdése. Kétségbe vonja, hogy egy vizsgálat, bizonyos feladatok megfejtése alkalmas-e rá, hogy általa megismerjük a gyermek „lelki sajátosságait”. Álláspontja szerint minden teszt „Janus arcú" - más a vizsgáló és más a vizsgált személy szempontjából. William Sternt idézi, aki szerint tesztekkel olyan tulajdonságok vizsgálhatóak, amelyek viszonylag állandóak és amelyek elemi - nem összetett - jelenségek. Márpedig az „állandóság követelése kizárja a szerzett tudás vizsgálatát”. A gyakorlás révén szerzett tudás ugyanis elfedheti a képességet, illetve a képesség hiányát. Hermann egyetért Révész Gézával, aki szerint a tesztvizsgálat sematikus, az intelligenciának csak bizonyos oldalaira vet fényt és csak tömegvizsgálatokat elégít ki; sem egyéni képességek mérésére, sem a tehetségek vizsgálatára nem alkalmas. A feladathelyzet ugyanis nem kedvez a spontaneitásnak - írja le Hermann. Összességében arra az álláspontra helyezkedik, hogy a tesztek csak felületes „tüneti” jellegzetességeket képesek bemutatni, amelyek csupán egy-egy elkülönült képességre nézve mérvadóak (Hermann, 1919. 191. o.).

Boda István, az 1928-ban útjára induló Magyar Pszichológiai Szemle főszerkesztője szintén szkeptikus az intelligencia univerzális jellegével kapcsolatban. Az ő meghatározása szerint az értelmesség különböző képességek szervezett rendszere, amelyben vannak általános - lényeglátás, kritikai képesség; speciális - logikai, oki gondolkodás -, és formai képességek, mint a gyorsaság és az elevenség. Emellett azonban - hívja fel Boda a figyelmet - a teljesítményeket befolyásolják az érdeklődés és az érzelmek is. 1931-ben megjelent írásából szó szerint idézünk: „Bizonyára nem véletlen, hogy eddig nem mutatta ki senki, hogy az intelligencia fogalmába pontosan ezek és ezek az értelmi értékek tartoznak bele.Voltaképen az, amit intelligencia szóval ártalában érteni szoktunk, nem is minden történeti korban, nem minden emberfajnál és népnél, nem minden éghajlat alatt, nem minden társadalmi osztály tagjai számára és nem minden körülmények között stb. stb. ugyanaz az egy, egyszer s mindenkorra pontosan megállapítható azonos összetevőkkel és pontosan ugyanazon összetevődési, organizációs viszonyokkal bíró valami. Az általánosan intelligensnek mondott angol bizonyára nem pontosan ugyanazon jellegú és összetevődöttségú intelligencia által ítéltetik intelligensnek, mint például az otthonában intelligensnek tartott hindu, vagy az intelligensnek tartott kínai; a középkori intelligens ember bizonyára nem ugyanazon tényezők birtokában vált intelligenssé, mint a huszadik században intelligensnek tekintett ember; de csak a közép és felső osztályok intelligenciája is összetevőiben is más, semmint az alsó osztályoké, az iparosé is voltakép más, mint a földmúveloé és más, mint a kereskedoé, a 
kereskedő viszont más lelki tényezőknél fogva tartatik intelligensnek, semmint a tudós stb... hiszen pl. még a gyakorlatban jól bevált Binet - Simon gyermeki intelligenciavizsgálati rendszer is a különféle fajú és nemzetiségú gyermekek sajátos intelligenciájánnak megfelelően országonként való módosításokra kényszerült (és e módosítási kényszer nem magyarázható egyedül csak a más-más nemzetbeli gyermekek fejlődési különbségeivel)." (Boda, 1931. 29. o.).

A hazai pszichológia fiatal tehetsége, Harkai Schiller Pál is komplexebbnek véli az értelem múködését, mint amit egy teljesítmények értékelésén alapuló adatsor tükrözhet. A Magyar Államvasutak pszichotechnikai laboratóriumában és a honvédség Képességvizsgáló Intézetében több mint ezer érettségizett fiatalembert vizsgáltak pályaalkalmasság szempontjából. A feladatokat maga H. Schiller állította össze más tesztekből. Segítségükkel a megfigyelést, a lényeglátást, a matematikai intelligenciát és a logikus következtetés képességét vizsgálták. Az értelemvizsgálatok mellett „cselekvéspróbát” is alkalmaztak, amely feltevésük szerint a jellembeli sajátosságok megismerését szolgálta. $H$. Schiller azt is megállapítja, hogy a teszteredmények függetlenek az érettségin való bukástól: a bukottak között ugyanannyian voltak a jól teljesítők, mint a teszt alapján gyengébb értelmúek. Azok, akik jeles vagy jó eredményt értek el az érettségin, magas pontszámot értek el a tesztvizsgálatokban is, összességükben azonban a teszteredmények csak mintegy 16\%-ban mutattak egyezést az érettségi eredményével. Mindebből Harkai Schiller arra a következtetésre jut, hogy az érettségi bizonyítvány eredménye nem tükrözi a gyakorlatban is alkalmazható képességek színvonalát: a megfigyelőképességet és a józan értelmet, vagyis a pszichológiai értelemben vett intelligenciát. Úgy véli, hogy a „szabadon osztályozott teljesítménybecslés" megbízhatóbb, mint a statisztika és Németországban is egyre inkább ezt alkalmazzák a pontozással szemben. Fontosnak tartja, hogy a vizsgálómódszerek segítségével következtetni lehessen az érzelmi, akarati tulajdonságokra is (Harkai Schiller, 1935. 432. o.).

Egy másik, Komjáthy Zoltánnal írt tanulmányában alacsony iskolázottságú sorkatonák vizsgálatáról számol be. Felfigyelnek rá, hogy a vizsgált személyek nem egyszerúen nem találnak rá a helyes megoldásra, hanem másfajta gondolkodásés következtetésmód jellemzi őket. A jelenséget példák sokaságával világítják meg: amikor egy fogalom felsőfogalmát kellett megadni, a megkérdezettek a „,tarisznyát” a ruhák, a „hízót" az ételek, a „,borjúsültet” pedig állatok kategóriájába sorolták, amikor pedig a „kés, villa, fúrész, kasza” csoportból a nem odaillőt kellett volna megjelölni, a jellegzetes válasz a „kasza” volt a „villa” helyett. A matematikai jellegú feladatban a 20 és a 60, illetve a 30 és a 70 közé eső számokat kellett kiválasztani egy 12 tagú számsorból. Ebben az esetben jóval többször hibáztak a második esetben, holott logikai szempontból semmilyen különbség nincs a két intervallum között. Annak sincsen egyértelmú racionális magyarázata, miért bizonyult könnyebbnek a vizsgált személyek számára egy számsorból a 4-el osztható számok megtalálása, mint a 3-al oszthatóké. Harkaiék 
következtetése szerint az „iskolázatlan logika” nem azonos a „relációs logiká”val. A vizsgálatban résztvevő, pallérozatlan gondolkodású személyek az együtt tapasztalt, érintkező, vagy egymásból származó dolgokat tartották egy osztályba tartozónak- állapítják meg. A képességmérés azonban torz eredményekre fog vezetni, ha a vizsgálók nem veszik figyelembe a gondolkodásbeli különbségeket. A vizsgálati szempontokat a vizsgálandóktól kell tanulni - hívják fel a figyelmet a szerzők. A képességmérésnél nem elegendő a sztenderdizálás, hanem szükség van az előzetes kipróbálásra, más tesztekkel való összehasonlításra, a tipikus hibák kiszúrésére - ezt a folyamatot a szerzők kalibrálásnak nevezik. A képességmérésnek nem elvont normákhoz, hanem az emberi természethez kell alkalmazkodnia - összegzik a tapasztalataikat (Komjáthy és Harkai Schiller, 1938).

A képességek autentikus vizsgálatának problémája áll Baranyai Erzsébet érdeklődésének középpontjában is - ő a kevesek egyike, aki a világháború után is Magyarországon marad és 1960-ban részt vesz az Éltes-Binet-teszt korszerúsítésében (Czeizel és mtsai, 1978). 1929-ben beszámol amerikai tapasztalatairól a képességméréssel kapcsolatban. „A gyermek értelmi állapotának felmérése ma láz Amerikában” - írja a Széphalom címú folyóiratban. „Megmérnek minden funkciót, megmérnek mindent, ami megmérhető és meg nem mérhető, azaz, hogy ilyen nincs is az amerikai szerint, mert ami létezik, az kvantitásban létezik". Az intelligencia mértéke pontokban fejeződik ki, az idiótától a géniuszig - országos felzúdulást váltott ki, hogy megmérték egy egyetem hallgatóinak intelligenciáját, és az meglepően alacsonynak bizonyult. Ám az Egyesült Államokban vezéreszme, hogy minden korrigálható - tudósít. Az iskolákban vannak „orvosló kurzusok, orvosló számtan és orvosló olvasás”, a pszichológia osztályon a gyermek magatartását orvosolják. Baranyainak imponál, hogy fontosak a tanórán kívüli foglalkozások, a sport, a múvészetek, valamint, hogy a középiskola ingyenes és a gyerekek 33\%-a be is iratkozik - ez abban az időben igen magas aránynak számít. De kurzusokra járnak a felnőttek, sőt az idősek is (Baranyai, 1929. 324. о.).

Ő azonban nem elégedett az intelligencia tesztekkel végzett vizsgálatával, a tartalmi különbségeinek fontosságára, a gondolkodás, értelmi képességek egyedi voltára hívja fel a figyelmet a Magyar Pszichológiai Szemlében megjelent írásában (Baranyai, 1938). Kifogásolja, hogy az értelmi képességeket "szkémákhoz" igyekeznek hasonlítani, holott az mindenkinél más formát ölt. A „magasabb rendú értelmesség”, az alkotóképesség egyáltalán nem vizsgálható statisztikai eszközökkel, a gondolkodás folyamata legalább olyan fontos, mint az eredményszögezi le, kiemelve, hogy a gondolkodást az érzések is alakítják, és az érzéseket is magában foglaló gondolkodás az igazán magas szintú gondolkodás. Egy másik tanulmányában (Baranyai, 1939) kritikai éllel ismerteti a Binet-tesztet. Az értelmesség nem egyértelmú dolog - szögezi le. A magasabb rendú értelmesség egynemú, affektív szinezetú, egyéni sajátosságokat hordozó szellemi erő, amely „objektív gondolati tartalomhoz illeszkedve új és átfogó gondolati struktúrát 
alkot" (Baranyai, 1939. 12. o.). Ez a tulajdonság tesztekkel nehezen vizsgálható, mert minőségi és nem mennyiségi - állapítja meg. A vizsgálatára különböző módszerek léteznek, mint például hiányos mondatok kiegészítése, értelmetlen szóhalmazok mondattá formálása, abszurd ítéletek helyességének, vagy helytelenségének megítélése. Ő maga is végez ilyen kísérletet: az általa vizsgált gyerekeknek történeteket kellett befejeznie. Az egyik ilyen történetben egy gyerek gyönyörú játékot kapott ajándékba, de nem játszik vele; egy másikban biciklit ajándékoztak neki a szülei, anyja aggódik miatta, apja nem. A válaszokat minőségi szempontok alapján igyekeztek értékelni, a jellegzetes választípusok megalkotásával.

Somos Gyula 1938-ban már egyenesen elavultnak véli a Binet-Simon-tesztet. Álláspontja szerint gyökeresen különbözik a gyermek és a felnőtt gondolkodásmódja, ezért az intelligenciájuk mérésének is más módszerekkel kellene történnie (Somos, 1938.).

Az értelmességgel kapcsolatos diskurzusba beszúrődnek a vesztes háború és a területveszteség okozta elkeseredettséget tükröző hangok is. Ballai Károly (1929) szerint a magyar gyermekek minden más gyermektől különböző tulajdonságokkal rendelkeznek, és ezt egyebek között azzal támasztja alá, hogy Éltes a Binet-teszt adaptációja során különbségeket talált a francia és a magyar gyermekek teljesítménye között. Véleménye szerint a magyar gyermekeket, akár a felnőtteket, igen erős „faji, hazafias érzés” jellemzi. A magyar gyermek elsősorban a történelmet szereti, „mert abban fajtája hősi küzdelmeiről olvas, a nemzet fenntartó harcait ismeri meg. A józan gondolkodás gyökereit is megtaláljuk", míg az anyagi érdeklődés kevésbé jellemzi a magyar gyermeket. (Ballai, 1929. 80. o.) „Akaratmúködésében feltúnő a harc, a küzdelem iránti hajlandóság. Ezen a téren, akár a felnőtt, elszánt és határozott" (Ballai, 1929. 82. o.).

\section{EPILÓGUS}

A közeledő második világháború, a szakemberek kivándorlása, a szakmai körök felbomlása véget vet az értelmi képességek mérhetőségével kapcsolatos töprengéseknek és vitáknak. A baloldali diktatúrában az intelligenciamérés bírálatának politikai színezete lett, amely része volt a pszichológia elutasításának. Később, az enyhülés idején, az 1960-as évektől a hazai pszichológusok is egyre szélesebb körben alkalmazták a mindenkori képességmérések alapját jelentő IQ teszteket, immár kétségek és kritikai hangok nélkül.

\section{FELHASZNÁlt IRODALOM}

Ballai Károly (1929): A magyar gyermek. Magyar Gyermektanulmányi Társaság, Budapest.

Baranyai Erzsébet (1929): Amerikai nevelés. Széphalom, 3. 9-10 sz. o.n.. 
Baranyai Erzsébet (1938): A magasabbrendú értelmesség meghatározása és vizsgálatának módszere. Acta Litterarum ac Scientiarum Reg. Universitatis Hung Francisci-Iosephinae, Szeged.

Baranyai Erzsébet (1939): Értelmesség és egyéniség. Magyar Pszichológiai Szemle, 12. 1-4. sz. 22-29.

Binet, A. (1900): La Suggestibilité. Scheicher, Paris.

Binet, A. (1916): Az iskolásgyermek lélektana. Magyar Gyermektanulmányi Társaság, Budapest.

Berkovits René (1913): A gyermeki intelligencia vizsgálata. A gyermek, 7. 6. sz. 393-410.

Boda István (1931): A következtető képesség, mint értelmiségvizsgálati probléma. Magyar Pszichológiai Szemle, 4. 1-2. sz. 26-79.

Czeizel Endre, Lányiné Engelmayer Ágnes és Rátay Csaba (1978, szerk.). Az értelmi fogyatékosságok kóreredete a „Budapest vizsgálat” tükrében. Medicina Kiadó, Budapest.

Csillag Lipót (1918): Helyes-e a gyermekeket intelligenciájuk szerint elkülönítve külön osztályokban tanítani? Nemzeti Kultúra, 4. 1-2. sz. 2-3.

Deák Gábor (2000): A magyar gyermektanulmányi mozgalom története. Fővárosi Pedagógiai Intézet, Magyar Pedagógiai Társaság, OPKM, Budapest.

Donner Lajos (1899:) A gyermek értelmi fejlődése gyermekpsychologiai szempontból. Corvina, Békéscsaba.

Éltes (Ellenbach) Mátyás (1902): A gyengeelméjüek világából. Neuwald Kiadó, Budapest.

Éltes Mátyás (1914a): A Binet-Simon féle intelligenciavizsgálat eredménye magyar gyermekeken. A Gyermek, 8. 4. sz. 257-274.

Éltes Mátyás (1914b): A gyermeki intelligencia vizsgálata. Atheneum, Budapest.

Éltes Mátyás (1915): Hol kellene hazánkban kisegítő iskolákat állítani? A Gyermek, 9. 3-4. sz. 107-112.

Éltes Mátyás (1928): Iskolák szekunda nélkül. Magyar Gyógyedagógus, 16. 4-6 79-82.

Eperjessy István (1906): A népiskolába lépő gyerekek ismeretvilága. Népmüvelés, 2. 7-12 125-135.

Focher László és Szondi Lipót (1919): A szellemi képességek korellációi gyermekeken és kismúveltségú felnőtt egyéneken. A Gyermek, 13. 2. sz. 199-209.

Gál Anikó (2012): A gyermektanulmányozás és a gyógypedagógia kapcsolata Magyarországon a 20. század első felében. 62. 11-12. sz. 224-234. online: http://epa.oszk.hu/00000/00035/00155/pdf/EPA00035_upsz_2012_ 11-12_224-234.pdf megtekintés: 2016.09.01.

Gordosné Szabó Anna (1991): Éltes Mátyás: egy követésre méltó életút. Gyógypedagógiai Szemle, 19. 4. sz. 282-287.

Gould, S. J. (1999): Az elméricskélt ember. Typotex, Budapest. 
Harkai Schiller Pál (1935): Érettségizettek értelemvizsgálata. Magyar Pszichológiai Szemle 8. 3-4. sz. 425-435.

Hermann Imre (1919): A tesztvizsgálat módszertani elvei. A Gyermek, 13. 2. sz. 188-198.

Komjáthy Zoltán és Harkai Schiller Pál (1938): Értelempróbák szerkesztése. Magyar Pszichológiai Szemle, 11. 1-4. sz. 141-157.

Kun Miklós és Szegedi, Márton (1978, szerk): Az intelligencia mérése. Medicina, Budapest.

Mészáros István, Németh András és Pukánszky Béla (1999): Bevezetés a pedagógia és az iskoláztatás történetébe. Osiris Kiadó, Budapest.

Nagy László (1906): A gyermektanulmányozás mai állapota. A Magyar Filozófiai Társaság közleményei, 6. 2. sz 57-90., 3. sz. 143-151.

Nagy László (1912): Iskolás gyermekek értelmességének vizsgálata. (könyvismetetés) A Gyermek, 6. 2. sz. 89-91.

Nagy László (1926): Beszámoló a gyermeki egyéniség vizsgálati módszereiről. A Gyermek, 96-104.

Pethes János (1901): Gyermekpsychológia. Lampel Kiadó, Budapest.

Pléh Csaba (2000): A lélektan története. Osiris Kiadó, Budapest.

Pléh, Csaba (2004): Magyar hozzájárulások a modern pszichológiához. In: Pléh Csaba és Boross Ottília (szerk.): Bevezetés a pszichológiába. Budapest, Osiris Kiadó.

Pléh, Csaba (2009): Révész Géza - a sors feszültségei levelezése és székfoglalója tükrében. Thalassa, 20. 4. sz. 75-100.

Pukánszky Béla (2001): Felméri Lajos ismeretlen arca - a gyermekkép újszerú vonásai az első kolozsvári pedagógiaprofesszor írásaiban. In: Csapó Benő és Vidákovich Tibor (szerk.): Neveléstudomány az ezredfordulón. Nemzeti Tankönyvkiadó, Budapest. 423-432.

Somos Lajos (1938): Az intelligencia (értelmesség) és nevelése mai megvilágításban. Néptanítók lapja, 71. 14. sz. 568-571.

Szabolcs Éva (2002): A gyermektanulmányi szemlélet megjelenése a magyar pedagógiai sajtóban 1890-1906. Iskolakultúra, 12. 3. sz. 33-38.

Vajda Zsuzsanna (1995): A pszichoanalízis budapesti iskolája és a nevelés. Sík Kiadó, Budapest.

Vajda Zsuzsanna (2017): Hosszú haj, rövid ész? Férfiak és nők értelmi képességei a legújabb kutatások tükrében. Magyar Tudomány, 178. 3. sz. 322-336. 


\title{
Oktatáspolitikai irányváltás a Szovjetunióban: egy iskolareform anatómiája (1958)
}

\author{
SOMOGYVÁRI LAJOS
}

\begin{abstract}
Pannon Egyetem Tanárképző Központ
Az államszocialista berendezkedés közoktatást érintő legjelentősebb átalakítási kísérlete 1958-ban kezdődött meg a Szovjetunióban, majd az egész keleti blokkon végigsöpört, melyhez a mintát az írásomban bemutatott folyamat adta. A kísérlet a hatvanas évek közepére, végére megbukott, azóta sem született átfogó, kritikai megközelítése a témának - ez persze a szocialista pedagógia jelentős részére igaz. Az iskolareformként definiált változtatásokat a politechnika, a munkára nevelés és gyakorlati oktatás jelszavai határozták meg, napjainkban is releváns kérdéseket felvetve, mint például az általános- és szakképzés viszonya, a korszerû múveltség mibenléte, vagy iskola és élet kapcsolata.

Tanulmányom a szovjet döntéshozatali mechanizmus, a különböző érdekcsoportok artikulálódó igényeit elemzi, melyek egy szimulált, kontrollált nyilvánosság kontextusában jelentek meg. A Hruscsov által kezdeményezett új szakasz tudatosan vont be szakértőket a tervezésbe, előkészítésbe, mellyel megosztotta a felelősséget, felmérte és leszerelte a lehetséges ellenvetéseket, valamint „megdolgozta” a közvéleményt, lefordítva a gyakorlat nyelvére a tennivalókat. Az ideológia és a pártirányítás primátusa nem kérdőjeleződött meg, de a döntéshozatal módosult a sztálini időszakhoz képest. A változtatás igényének felmerülése azonban Sztálin utolsó éveihez köthető, ezért innen kell kezdeni az elemzést.
\end{abstract}

\section{VITÁK A SZOVJET ISKOLÁRÓL}

Az 1958-es szovjet iskolareformot hosszú vita előzte meg. Sztálin egyik utolsó írása (1952) vetette fel a húszas évek óta először az általános politechnikai oktatás bevezetésének szükségességét, mely egyaránt fontos volt a társadalom kulturális átneveléséhez és - a hivatásválasztás előbbre hozásával - a gazdasági erők fejlesztéséhez. Az ideológiai és gazdasági érdek legitimációja, a kettős hivatkozás a későbbi diskurzus lényegi ismertetőjegyévé vált. Kalmár Melinda 
magyar történész az ötvenes évek első felének rendszerátalakító tendenciájaként értékeli a szovjet fejleményeket: a tudományos-technikai forradalomhoz való adaptációs kényszer, majd az átalakuló kelet-nyugati kapcsolatok, a hruscsovi koegzisztencia és verseny mind-mind abba az irányba terelték a döntéshozókat, hogy változtassanak a technológia, a gazdaságszerkezet, az állami és pártirányítás, valamint az oktatás területein. Célkitûzéssé vált a versenyképesebb tudás, szakképzettebb munkaerő létrehozása, mely alkalmazkodni tud a megváltozott körülményekhez és hatékonyabban képes múködni. Kalmár szerint az új szakasz formálódása 1951-1952-ben kezdődött, mikor már olyan válságjelek mutatkoztak a keleti blokkon belül, ami elodázhatatlanná tette a rendszer módosítását ezt a folyamatot Sztálin 1953-ban bekövetkezett halála csak felgyorsította (2014. 69-89. о.).

A XIX. kongresszus foglalta először direktívákba a teendőket az oktatást illetően (1952), a megvalósítás azonban csak nagyon lassan haladt előre: alsó fokon bevezették a kézimunkát (I-IV. osztály), felsőfokon a múhelyekben és mezőgazdaságban végzett gyakorlati tevékenységet (V-VIII., illetve X. osztályig) - az új tantárgyak és tevékenységformák bevezetése 1956-ig húzódott (DeWitt, 1961. 9. o.). Az 1956-os XX. kongresszuson Hruscsov vádbeszédet tartott a szovjet iskolarendszer ellen: a diákokat az intézmények nem készítik fel a gyakorlati életre, a XIX. kongresszus irányvonala nem valósult meg (1956). A következő két év a szovjet neveléstudomány, a pedagógusok, a politikusok és a közgazdászok/gazdasági tervezők vitáival telt el; ideológiai, szakmai és népgazdasági érvek egyaránt szerepet kaptak az eltérő nézetek közti konfliktusokban. Többek között a Szovjetszkaja Pedagogika adott teret a vitának, az ideológiai szempontok (Marx és Lenin tanításainak értelmezése) mellett a pártirányítás kívánságai (a XX. kongresszus irányvonala), a pedagógiai igények (új tantervek, a termelés alapjai tantárgy bevezetése) és a gazdasági fejlődés (mezőgazdaság, gép-, vegyipar, energiatermelés) támasztotta követelmények egyaránt előfordultak a diskurzusban (Szkatkin, 1958).

Az új tantárgyak, a gyakorlati képzés bevezetése (kötelező nyári gyakorlat formájában) szükségszerúen túlterheléshez vezetett, amit a vizsgák eltörlésével próbált megoldani az oktatásirányítás (DeWitt, 1961. 10. o.) - ezzel viszont újra előtérbe került az általános képzés és a szakképzés egyensúlyának megbomlása, a középiskola funkcióiról, funkcióváltásáról szóló viták megszaporodása. A Szovjetunióban a 10 éves, egységes iskola volt a cél, ami a valóságban 7 illetve 8 osztályos intézményekben realizálódott, mivel hiányoztak az anyagi, személyi és infrastrukturális elképzelések az eredeti terv megvalósításához - a 10 osztályos iskolák végül csak a nagyvárosokban jöttek létre (a szovjet iskolatípusokhoz ld.: Kairov, 1963). Az egységes iskola koncepciójának alapja az oktatási rendszer egyenlősítő funkciójáról vallott elv volt: a különböző társadalmi háttérből érkező gyermekek egy múveltségi szintre hozása, ami a szocialista pedagógia esetében a munkás-paraszt származású fiatalok helyzetbe hozásáról szólt. A szovjet 
egységes iskola integratív szándéka, a kollektív nevelés nem állt távol a nyugati tendenciáktól: az USA egységes iskolái külsőre hasonlóak ehhez a rendszerhez, illetve a komprehenzív iskolák feltúnése is analóg jelenség a hatvanas évek skandináv államaiban. A középfokú képzés minél teljesebb kiterjesztése szintén közös célként tételeződött a különböző iskolarendszerekben (az USA és a SZU iskolarendszerének összehasonlítása: Mitter, 1981; az egységes középiskola megteremtésének kísérletéről: Setényi, 1992; ennek elméleti alapja: Szebenyi, 1997).

Az egységes iskola elképzelésével szemben már 1956-ban felmerült a hosszabb távú gazdasági célokat szolgáló, pedagógiai szempontokkal is alátámasztható furkáció bevezetésének igénye. Ez azt jelentette, hogy az egységes közös képzés idejét lerövidítik és a diákokat már korábban a szakma/hivatás választásának eldöntésére késztetik - az így meghozott választás alapján a továbbiakban elválnak a képzési utak és különböző speciális képzési formákban részesülnek a tanulók. A leningrádi oktatási szakemberek által képviselt, a Literaturnaja Gazetában megjelent cikk ezt az irányvonalat képviselte 1956 decemberében és a Neveléstudományi Akadémia is ebben a formában foglalt állást a reformokat illetően 1957 elején. Az első 8 év után három irány közül választhattak volna a fiatalok: a fizikai, matematikai, technikai orientáció az ipari képzés céljait szolgálta, a biológiai a mezőgazdasági termelés felé vezetett, míg a humán változat a szolgáltatások, a leendő értelmiség tagjainak utánpótlását biztosította (a cikk és az Akadémia álláspontjához: DeWitt, 1961, 11-12, az Akadémia 1957-es, 1958-as szerepéről: Medlin, 1958).

Az 1956-1957-as tanévben már 585 iskolai kísérlet folyt az OSZSZSZK-ban a politechnika bevezetéséről, miközben az Akadémia az új óra- és tanterveken dolgozott. Az első négy osztályban kézimunka-tanítás folyt, ötödik és nyolcadik között múhelygyakorlatok, az utolsó három évben új tantárgyként bevezették az Ipari és mezőgazdasági termelés alapjai címú tantárgyat (Faragó, 1958). A tanmúhelyekben végzett gyakorlatot az órarenden kívüli, őszi és tavaszi munkákban való részvétel egészítette ki, a mi felső tagozatunknak megfelelő iskolafoktól, vagyis az ötödik osztálytól kezdve (Szovjetunió ..., 1958). Az elért eredmények alapján a kísérleteket összefoglaló 50 kutató lehetségesnek (de nem szükséges elemnek) tartotta egy szakma elsajátítását normál középiskolai oktatás keretében, ugyanakkor a túlterhelés problémája továbbra sem szû́nt meg (Ábent, 1958a). Az átalakítás előkészítésében és lefolytatásában nagy szerepet játszott a propaganda, ennek érdekében 1957 januárjától új folyóiratot indított az OSZSZSZK Közoktatásügyi Minisztériuma, Politechnicseszkoe Obucsenyije (Politechnikai Képzés) címmel (Faragó, 1957). A kérdés már csak az általános és szakmai képzettség egyidejú megszerzéséhez vezető út volt: a Minisztérium 1958 tavaszán a diverzifikált középfokot hagyta jóvá, amely az általánosan képző iskolák esetében a munkára nevelést több irányt is megalapozó szakmai előképzésként, jobb esetben szakképzésként fogta fel, emellett pedig meghagyta volna a korábbi szakképzési 
formákat. Azonban nem a furkáció intézményesült, hanem a gyorsabb megtérülést ígérő, közvetlen szakképzés (egy-egy szakmára való specializálódás) valósult meg a nyolcadik osztály után - azaz megmaradt az ideológiailag is fontos egységes (és egyenlősítő) iskola, a munkára nevelés formái pedig az aktuális és helyi, konkrét igényeknek megfelelően alakultak ki. A munkára nevelés irányvonalát végül a pártvezetés fellépése, egyéb érdekcsoportok igényei és a változó geopolitikai konstelláció alakította ki.

A kelet-nyugati kulturális kapcsolatok megélénkültek az ötvenes évek végén (párhuzamosan az ûrversennyel) - a szovjet oktatást átalakító kezdeményezések valójában világméretú tendenciákba illeszkedtek, ahogyan azt már korábban is láthattuk. 1958 áprilisában az UNESCO konferenciát tartott Sèvres-ben, ahol a középiskolai képzés aktuális kérdéseiről volt szó: a tankötelezettség felemelése, a korszerú múveltség tartalma, az általános és szakképzés viszonya a szovjet diskurzusban is gyakran előforduló témák voltak. Ebben az internacionális környezetben a szovjet küldöttség beszámolója nagy érdeklődésre tartott számot, hiszen a svéd és francia iskolareformokat is hasonló motívumok vezették ebben az időben (Jóború, 1958, 1961. 3-6. o.; UNESCOa, 1958). A XXI. Nemzetközi Nevelésügyi Konferencia előadói szintén a fejlődés új követelményeit akarták összhangba hozni az oktatási szerkezettel, a Szovjetunió és a szocialista országok a politechnika bevezetésével vélték ezt megoldhatónak (Csoma, 1958; UNESCOb, 1958). Nem tudjuk, hogy mekkora hatással lehetett a nyugati, haladónak nevezett pedagógiai irányzatok kezdődő recepciója a szovjet döntéshozatalra, ${ }^{1}$ majd a keleti blokkban beinduló folyamatokra, de úgy tûnik egy újabb területe nyílt a nyugati és keleti blokk közti versenynek.

A sèvres-i UNESCO konferencia időpontjában Hruscsov Magyarországra látogatott: a gesztus a konszolidálódó kádári rendszer támogató megerősítéseként volt értékelhető, mely hazánkat újra és végleg betagolta a szocialista országok táborába. A látogatás egyik fontos állomása volt a szovjet pártvezér Akadémián mondott ünnepi beszéde április 9-én. Hruscsov igyekezett megnyerni a magyar értelmiség színe-javát, kiemelte a múvelőés fontosságát „a különböző rendszerek békés versenyében" és meghirdette a közoktatás meginduló felülvizsgálatát - „új Szputnyik lesz a közép- és felsőfokú oktatás tervezett megreformálása” (Feljegyzés..., 1958). A békés egymás mellett élés, az enyhülés és a verseny, a feszültség kiéleződésének jelszavai egyébként gyakran váltogatták egymást az ötvenes évek végén, az aktuális geopolitikai igényeknek megfelelően, ami megnehezíti a korabeli források értelmezését.

\footnotetext{
1959-ben például a Voproszi Filozofii (A Filozófia Kérdései) címú szovjet folyóiratban ismertették az amerikai Viktor Perlo tanulmányát a tudományos-múszaki forradalomról (Simon, 1960). Igaz, Perlo az USA Kommunista Pártjának egyik vezetője és marxista közgazdász volt, de korábban elképzelhetetlen lett volna, hogy hasonló nyilvánosságot és elismerést kapjon egy nyugati tudományos cikk. Az oktatás átalakításának kelet-nyugati összehasonlításáról hasonló cikkek jelentek meg ebben az időszakban (Bori és Tihanyi, 1957).
} 


\section{HRUSCSOV FELLÉPÉSE}

A reformként definiált változtatások egy másik beszéddel kezdődtek - 1958. április 18-án Hruscsov a Komszomol XIII. kongresszusán tartott nagyhatású referátumot. A megszólalás újra az iskolák elleni vádbeszédként hatott: a pártvezér szerint alapvető hiányosság, hogy az iskola el van választva az élettől és a termeléstől, nem készít fel a társadalmilag hasznos munkára és a gyakorlati életre. Ezzel együtt jár a morális nevelés elhanyagolása, a fizikai munka lebecsülése (, $\mathrm{Az}$ iskolákban még nem eléggé oltják bele a gyermekekbe a munka megbecsülését...") és a felsőoktatásba való bejutás túlhangsúlyozása. A fiatalok vonakodnak a végzés után munkát vállalni gyárban vagy gazdaságban, amit csak felerősít a szülők negatív hozzáállása a kérdéshez: aki nem tanul jól, az munkás lesz. Ennek ellensúlyozására az SZKP főtitkára szerint a főiskolai felvételiknél is előnyben kell részesíteni azokat, akiknek van munkatapasztalatuk, ösztönözni kell a már dolgozókat a továbbtanulásra, minimum a középfok megszerzésére („Minden fiatal munkásnak tanulni kell...”), valamint elengedhetetlen a felsőoktatás társadalmi összetételének javítása (Hruscsov, 1958a). Mindezek miatt radikális változtatásokra van szükség az oktatásban. A szovjet pártvezető itt már a termelőmunkára való általános felkészítésről, mindenoldalú fejlesztésról beszél, ami kimondatlanul is szemben áll a specializációval. Mindig figyelembe kell azonban venni, hogy a politikai vezetés csak általános irányelveket bocsátott ki, a megvalósítás ettől teljesen eltérhetett, jelen esetben is megvolt a kiskapu, a különböző termel̋ágak irányába való iskolai elágazások koncepciójának ismertetésével (DeWitt, 1961. 13. o.). A fó jelszó ettől fogva oktatás és termelőmunka összekapcsolása, az iskola és élet kapcsolatának megerósítése.

Hruscsov szerint a gyakorlati képzésben részt vevő tanulók a kommunista társadalom aktív felépítóivé válnak majd, az oktatási fordulatot az erkölcsi érvek mellett közgazdasági indokok is alátámasztják (Coumel, 2009. 67. o.). Ez utóbbi szempontot az 1959 elején meghirdetett 7 éves terv csak erősítette: az 1959 és 1965 közötti időszakra előirányzott tervszámok az USA gazdasági utolérésének nagy ívú programját hirdették meg (az egy főre jutó GDP-ben, 1970-ig), ehhez viszont pótlólagos munkaerőre volt szükség - a diákok jelenthették volna a hiányzó humán erőforrás egy részét. A Komszomol-beszéd a felzárkózás egy másik aspektusaként a tudományos-technikai fejlődéshez szükséges általános múveltség megemelésének igényét szintén meghirdette, ami a középfokú végzettség kiterjesztésének célkitűzését jelentette az egész népességre: „Amikor munkásainknak és kolhozparasztjainknak középfokú általános múveltségük lesz, munkájuk majd egyre termelékenyebbé fog válni, és a munka termelékenységének szakadatlan növelése jelenti éppen végső soron a kommunizmus sikeres felépítésének legfóbb feltételét." (A beszédet idézi: Nagy, 1958. 807. o.) A marxista elmélet szerint e folyamatban a fizikai és szellemi munka közti különbség elóbb-utóbb eltúnik, a bérek közti különbség csökken, vagyis megvalósul 
a kommunista utópia. Ehhez a technikai fejlődés nyújt majd segítséget, hiszen a távirányítás, az elektrotechnika és az automatizálás bevezetésének hatása a munkaidő csökkentése lesz, ezen rendszerek múködtetéséhez azonban értelemszerúen magasabb fokú szakképzettség szükséges (Osztrotyitanov, 1958). Ez a folyamat csak úgy válhatott teljessé, ha a nappali tagozat mellett az esti, levelező képzési formákat, illetve a dolgozók iskoláihoz hasonló intézménytípusokat továbbra is extenzív módon növelik, ami viszont együtt járhatott a megszerzett képzettség színvonalának csökkenésével - jóllehet az eredeti cél éppen a szakképzettségi szint emelése volt.

Az akadémiai szféra képviselőinek többsége ezzel szemben még mindig ragaszkodott a furkáció koncepciójához, habár a kérdés már eldőlt: Goncsarov a Szovjetunióba látogató Nagy Sándornak, a Pedagógiai Tudományos Intézet igazgatójának még 1958 májusában is az általános múveltség megalapozásában, a politechnikai képzésben és egy speciális munkaterületen való elmélyedésben határozta meg az új középiskola feladatait (Nagy, 1958. 808. o.). Ebben az időszakban megszaporodtak a nyugati látogatások is a Szovjetunióban, ezek a beszámolók szintén megerôsítik a politikai-gazdasági szféra és az akadémiaiszakmai világ ellentétét (ld. pl.: Rudman, 1959). ${ }^{2}$

Zelenko, a Munkaerőtartalékok Hivatalának szovjet vezetője a gazdasági tervezés véleményét több cikkben ismertette 1958 nyarán (a Pravdában megjelent írások összefoglalásához ld.: DeWitt, 1961. 14. o.; Rudman, 1959. 254. o.). A 7 éves terv előkészítéseként Zelenko a szakképzett, betanított munkások kívánatos arányát jelölte ki, melyben az oktatás szerepét a szakképzésre és a munkaerő-tartalékok „kitermelésére” redukálta. A továbbtanulást a különösen tehetségesek számára tartotta volna csak fenn a hivatalvezető, a tervezet szerint a fiatalok többsége 15 évesen kerül majd a munkaerőpiacra, ezzel feladva a 10 éves egységes iskola ideálját. Az új kötelező, általános politechnikai iskola 8 osztályos lett, ezzel párhuzamosan az esti/ levelező képzések számát megnövelték, hogy a dolgozók a munka megszakítása nélkül teljesítsék az egész lakosságra kiterjedő középfokú végzettség célkitûzését. A reformot tehát a világszerte meginduló oktatási expanzió határozta meg, amit igyekeztek összhangba hozni a politechnika követelményeivel és a gazdaság igényeivel (Kálmán, 1958), ami természetesen sokszor vezetett összeütközésekhez a különböző szereplők között.

Ugyanezen a nyáron Hruscsov is elkészítette tervezetét az oktatási reformról, ami a Pravdában jelent meg 1958. szeptember 21-én - a dokumentumot legtöbbször Tézisek néven emlegették. A vita ezután kikerült a nyilvánosság terébe, ahol felülről irányított és ellenőrzött „társadalmi vita” kezdődött az

${ }^{2} \mathrm{Az}$ amerikai-szovjet rivalizálás a Szputnyik-sokk után az oktatás területére is kiterjedt, az általam elérhető beszámolók a szovjet iskolareformot általában pozitívan szemlélték (Lilge, 1959; Ross, 1960; Holmes, Read és Voskresenskaya, 1995. 19. o.). Ennek több oka is lehet: valószínúleg baloldali érzelmú amerikai pedagógusok és újságírók látogattak el a Szovjetunióba, illetve a mccarthyzmus természetes visszahatásának is tekinthető a szovjet törekvések irányában megnyilvánuló szimpátia. 
irányelvekről. 1958 őszén az SZKP KB és a Minisztertanács is jóváhagyta az iratot, ami így az év végén törvényerőre emelkedhetett.

\section{A TÉZISEK}

A Hruscsov-memorandum címe szinte teljesen megegyezett a később elfogadott törvény elnevezésével: $A z$ iskola és az élet kapcsolatának megszilárditásáról és a közoktatási rendszer továbbfejlesztéséről. ${ }^{3}$ A dokumentum lerövidített változatát közölte a Népszabadság (1958), illetve a magyar közéleti-pedagógiai sajtóban is hamarosan megjelent a Tézisek ismertetése (Hruscsov, 1958b; Ábent, 1958b) - a szöveg elemzése e három forrás felhasználásával készült. Hruscsov tételmondata szerint a szovjet iskola nem oldja meg az ifjúság életre való felkészítését, csak a továbbtanulást segíti elő (a Komszomol-beszéd felütése ugyanez volt). A reform indoklása jelezte, hogy melyik érdekcsoport igényei érvényesültek: az oktatás a nemzetgazdaság fejlődése szempontjából fontos, fel kell használnia a technológia és a tudomány új eredményeit. A mennyiségi eredmények ellenére (írásbeliség elterjedése) számos probléma maradt, a legfőbb gondot az iskola elszakadása jelentette az élettől, mivel az oktatási rendszer túlságosan támaszkodott a forradalom előtti gimnázium hagyományához, ami a diplomához szükséges akadémiai, absztrakt tudást adja meg csupán, de semmi köze nincs a termeléshez. Ennek oka az volt, hogy a szovjet rendszer első időszakában más volt még a prioritás, a felsőoktatást kellett feltölteni munkás-paraszt származású fiatalokkal. A lenini alapelvekhez való visszatérés jegyében (amire Hruscsov sokszor hivatkozott, hogy elhatárolja magát a sztálinista politikától) mindenoldalúan fejlett, a gyakorlati életben gyökerező személyiség kialakítása szükséges. Az ideális személyiségnek a következő két fontos jellemzője van: jól ismeri a tudományok alapjait (itt főleg a természettudományokról, illetve a tudományos-technikai forradalom keltette új kihívásokról van szó); illetve a fizikai munkavégzésre késznek kell lennie.

A célul kitűzött, 10 osztályos, egységes oktatást két részre osztotta a tervezet: az első 7-8 év az általános képzésé (de az első szakasz utolsó két évében is szükséges már bekapcsolni a tanulókat a kolhozok és vállalatok társadalmilag hasznos munkájába), az utolsó 2-3 év a szakképesítés megszerzésének időszaka, külön városi (ipari) és falusi (mezőgazdasági) változattal. A tankötelezettséget hétről nyolc évre emelték, ezt hívták a középfokú oktatás első szakaszának, vagy más néven „politechnikai, nem teljes középfokú munkaiskolának”. A második szakasz a teljes középfokú végzettség megszerzésének időszaka, többféle iskolatípus tartozik ide: politechnikai középiskola, technikum, munkás-, falusi ifjúság iskolái, a különleges tehetségú gyerekeknek külön múvészeti és természettudo-

\footnotetext{
${ }^{3} \mathrm{~A}$ később ismertetendő törvény így hangzott: Az iskola és az élet kapcsolatának megszilárdításáról és a Szovjetunió közoktatási rendszerének továbbfejlesztéséról. A szöveg egyébként számos ponton emlékeztet a Komszomol-beszédre.
} 
mányos (matematika, fizika, kémia, biológia) jellegú iskola. Külön kiemelték az általános középfok megszerzésének feltételét, amit a kommunizmus építésének feltételéül szabott a vezetés: „minden munkás és munkásnő, minden kolhozdolgozó - férfi és nő egyaránt - középiskolát végezzen...". A gyakorlati órák száma első és negyedik osztály között heti egy óra, ötödik osztálytól heti két óra lett. Nyolcadik után mezőgazdasági gépészeti és elektrotechnikai változatot alakítottak ki (Zibolen, 1958. 203. o.).

Nemcsak a középfokot, az egész iskolarendszert érintette a változás, ennek megfelelően a továbbtanulás új útjait vázolták fel a tézisek. A fő irány a termelőmunkában való részvétel és a tanulás egyidejú biztosítása volt, esti/levelező képzések számának növelésével, osztott tanítással, a felvételiknél kedvezmények biztosításával a munkás-paraszt fiataloknak. A felsőoktatást is közelebb vitték volna a munka világához, az első 2-3 évben még a termelőmunka mellett képzelte el Hruscsov az oktatást („nem szabad a diákokat elszakítani a termeléstől”), a harmadik évtől fokozatosan felmentést kaptak volna a hallgatók ez alól, az utolsó két év pedig csak a tanulásról szólt az eredeti tervek szerint. Később ezt a részt érintette a legtöbb kritika, így át is alakították a felsőoktatásra vonatkozó fejezetet. A javaslat külön kiemelte a mérnökképzés fontosságát és azokat a területeket, ahol ez jelentőségteli lesz a következó évtizedekben: az atomenergia, automatika, elektronika, rádiótechnika, villamosgép- és múszergyártás, hírközlés, valamint a kemizálás tartozott ide. A természettudományok mellett a társadalomtudományok (a marxizmus-leninizmus) szerepét is hangsúlyozta az irat, mivel a világnézeti tudatosságot minden szakember számára alapvetőnek gondolták.

\section{REFORM A NYILVÁNOSSÁG TERÉBEN}

A tervezett intézkedések - a termelési gyakorlat bevezetése a középfok utolsó kettő és a felsőfok első két évében, az esti/levelező oktatás kiterjesztése, a különlegesen tehetséges tanulóknak létesített speciális tudományos és múvészeti (előkészítő) iskolák - a felsőoktatásba bejutás keresztmetszetét szúkítve, a népgazdasági ágak felé terelte a tanulók többségét. Az irat nemzeti vitára hívott fel, amely szervezett és ellenőrzött formában a sajtóban történt meg, továbbá rengeteg találkozót, előadást is szerveztek a helyi pártbizottságok. Kairov túlzónak tûnő adatai szerint (1963) a nyilvános társadalmi vita során 299000 találkozó volt az Ukrán és az Orosz SZSZSZK-ban, melyeken 23 millió ember és 1300000 előadó vett részt 1958 decemberéig; a Pravda helyettes főszerkesztője, Gorjunov 14000 dolgozói levélről számolt be, ami a lapjához befutott a témával kapcsolatban (1959). A szimulált és kontrollált nyilvánosság, a különböző társadalmi-politikai és gazdasági érdekcsoportok igényeinek feltérképézése és korlátozott megjelenítése a Hruscsov által bevezetett új szakasz lényegi ismérve volt, ami együttjárt a szakmaiság bizonyos fokú érvényesülésével, szakértők 
bevonásával a döntéshozatal folyamatába (Kalmár, 2014. 104-105. o.) - az ő feladatuk elsősorban a már meghozott irányelvek legitimálása, konkretizálása volt.

Ebben az esetben a támogató hangok (Kairov, a Neveléstudományi Akadémia elnöke, Afanaszenko közoktatásügyi és Jeljutyin felsőoktatási miniszter) mellett kritikusabb hangok is megszólaltak: a tudományos élet képviselői főleg az általános múveltséget megalapozó szakaszt féltették, nem véletlen, hogy a novemberben újból előterjesztett és lerövidített tézis már kihagyta a felsőoktatás első két évének előírását a termelési gyakorlatról (Coumel, 2009. 69. o.). A diskurzusban természetesen a pozitív hangok domináltak (Megkezdődött a vita ..., 1958; Gorjunov, 1959), a kísérletek jó tapasztalatait és a "hatalmas népi mozgalom" erejét hangoztatták, ami a tézisek megjelenését követte. Kérdés persze, hogy valójában mennyire volt valódi a vita, hiszen a lehetséges kifogások feltérképezéseként is szolgálhatott a megindult nyilvános eszmecsere, hogy egyes elemek visszavonásával a vezetés megmutassa kompromisszumkészségét. Mindenesetre a Minisztertanács az újabb verziót egy időben jelentette meg a 7 éves terv célszámaival (Pravda, 1958. november 14. és 16., ld. DeWitt, 1961. 14-15. o.), amelyben külön fejezet szólt az oktatási reformról - erről később lesz még szó az SZKP XXI. kongresszusának ismertetésekor.

Ezt követően folytatódott a vita, Laurent Coumel francia történész a törvény ratifikálásáig terjedő időszakot (1958 szeptembere és decembere között) relatív pluralizmusnak nevezi, amikor különböző érdekcsoportok (szülők, pártirányítás, oktatási és gazdasági szakemberek) is kifejthették eltérő véleményüket. Nem véletlen, hogy a korabeli megszólalók gyakran peresztrojkának (átalakításnak) nevezték a reformterveket ${ }^{4}$ - a gorbacsovi időszakot jóval megelőzve. A beszámolók szerint két problémakör alakult ki a reformtervezet országos vitájában: egyrészről kifogásolták, hogy a főiskolai oktatás kezdetére tervezték a gyakorlatot, mert ez veszélyeztette a matematikai-múszaki múveltség megalapozását, másrészt kifogásolták a tehetségeseknek létrehozott külön iskolák ötletét (Szabó, 1958). 1958. december 24-én a Szovjetunió Legfelsőbb Tanácsa törvényerőre emelte a KB és Minisztertanács előterjesztését (az említett problémás részeket kihagyva), ezzel hivatalosan is bevezetésre került az új oktatáspolitika, az iskola és az élet kapcsolatának megerősítéséről szóló szlogennel, és lezárult (egy időre) a viták időszaka.

\section{Az OKTATÁSI TÖRVÉNY}

A törvényszöveg (Az iskola és az élet kapcsolatának megszilárditásáról és a Szovjetunió közoktatási rendszerének továbbfejlesztéséröl. Az elemzés alapjául szolgáló szöveget ld.: Kairov, Goncsarov, Jeszipov és Zankov, 1959. 511-528. o.) bevezetésében a

\footnotetext{
${ }^{4}$ Nikolaj Semenov, Nobel-díjas kémikus például a következő címmel publikált egy cikket 1958 októberében: Megjegyzések a peresztrojka néhány pontjáról (Coumel, 2009. 69. o.).
} 
széleskörú vita, mint legitimációs alap jelent meg, a jogalkotás ezek szerint a dolgozók egyetértésével és jóváhagyásával valósult meg. A régi marxi alapelv a fizikai és szellemi munka újraegyesítésérôl újra felbukkant, a jövő társadalmának felépítése csak így volt elképzelhető - Lenint Kairov idézi meg a reform egyik legfőbb hatásaként (1958. 5. o.). Az új embertípus kinevelése lett az iskolák feladata, a kommunista emberben harmonikusan egybeolvad majd a szellemi gazdagság az erkölcsi és fizikai értékekkel. A törvény sajátosan ötvözte a nevelési filozófia értéktételező nyelvezetét a tudományos-technikai terminológiával - az eszménykép felvázolásával párhuzamosan történt meg a népgazdasági érdekek artikulációja.

A termelés gépesítése, az automatizálás, a kemizálás, az elektronika és a villamosítás gyökeresen megváltoztatta a munka jellegét és az ehhez szükséges képzettséget - ez volt a másik fő indoka a változtatásoknak. A termelés bázisán, az állami gazdaságokban és a gyárakban megvalósuló gyakorlati képzés jelenti a fizikai és szellemi munka kettősségének meghaladását - a tudományos-technikai forradalom eredményei azonban nem teszik majd feleslegessé az emberi munkaerőt, csak magasabb szintre emelik annak közremúködését. A gazdasági növekedés eddigi ütemétól azonban elmaradt a szovjet iskolák teljesítménye, így szükségessé vált az iskola közelítése az élethez, azaz a szakember-utánpótlás biztosítása, a fiatalok aktív részvétele a társadalmilag hasznos munkatevékenységben, a kommunizmus felépítésében.

A változtatás, átalakítás valamennyi iskolatípusra kiterjedt. A törvény bevezette a 8 osztályos, nem teljes politechnikai iskolát, ami a termelés tudományos alapjai mellett a munkára nevelés gyakorlatát is tartalmazta. Ezt a 8 évet a munka mellett, immár a termelésben teljesen részt vevő dolgozók számára teljesítették ki: a dolgozók esti iskoláival, a múszaki technikumokkal és a politechnikumi munkaiskolákkal, ${ }^{5}$ - ez utóbbi nem összetévesztendő a 8 évfolyamos politechnikai iskolával! A cél a 15 - 16 éves kort elért diákok bekapcsolása volt a munkába, akik aztán önszorgalmukból, a munka mellett fogják elvégezni a középfokú végzettséghez szükséges három évet. Az eredeti akadémiai elképzelések ugyanezt a 11 évet egy integrált, egységes iskolában képzelték el, ami a fiatalok későbbi belépését jelentette volna a munkaerőpiacra - ezt ellensúlyozta volna a képzés megalapozottabb jellege.

A múszaki szakmai szakképzést és a szakiskolákat külön fejezetekben szerepeltette a jogalkotó, itt az önfenntartást túzték ki végcélként, amit a termelésben való fokozottabb részvétellel akartak elérni. A tanmúhelyek, üzemi-, kolhoziskolák és egyéb munkaszervezési formák ezért hangsúlyosabban szerepeltek

\footnotetext{
${ }^{5}$ A Szovjetunió iskoláinak többsége eddig 7 osztályos volt, de a nagyvárosokban megvalósultak az eredetileg létrehozni kívánt 10 osztályos intézmények. Az átalakítás mindkét típusra vonatkozott: 8 évfolyamra kellett kiegészíteni, vagy lecsökkenteni a tanintézményeket és ezek mellett létrehozni az esti/levelező intézményeket, technikumokat, vagy új iskolaként, vagy a felsőbb évfolyamokból kialakítva. A középfokú végzettséget a munkás- és parasztifjúság iskoláiban (3 év), nappali középiskolákban (3 év) és technikumokban (3-4 év) lehetett megszerezni (Jóború, 1961. 98. o.).
} 
ezekben a paragrafusokban. A felsőoktatásra szintén vonatkozott az élethez és termeléshez való közelítés igénye: a szakemberképzést jelölte meg a törvény a kibocsátás feltételének, illetve a felvételnél is előnyt élveztek azok, akiknek már volt gyakorlati munkatapasztalatuk. A munka és oktatás világát kölcsönösen közelebb kell hozni egymáshoz, amit elsősorban az esti/levelező képzések kiterjesztésével és a hallgatók gyakorlati munkavégzésével véltek megoldhatónak.

Az átalakításra az 1959/60. tanévtől számítva 3-5 évnyi időtartamot szántak, a törvényre a voluntarista jelleg és az ideológia túlsúlya nyomta rá a bélyegét: az ideális, felépíteni kívánt társadalom képét, és az ehhez szükséges embertípus kinevelésének kérdését tartalmazta a jogszabály, leírta a kommunista ember kívánt személyiségjegyeit, de az új oktatási rendszer felépítésének konkrét megvalósítására, a gyakorlati kérdésekre kevesebb figyelmet fordított. A közösségért élő, a munkát megbecsülő, az építésben aktív szerepet vállaló diák és hallgató képe többféleképpen volt értelmezhető és inkább a nevelésfilozófia, teleológia illetékességi területe volt. A pedagógia sollen jellege (Sáska, 2008) nyomult itt a jog absztrakt területére: az előíró normák azt írták le, hogy milyen legyen az új ember, csakhogy ez alapvetően idegen volt a törvény nyelvétől. A létrejött jogszabály általános kereteket adott, amit sokféleképpen lehetett tartalommal megtölteni és kevéssé lehetett ellenőrizni, hogy mikor, milyen feltételek létrejötte esetén valósulnak meg a célkitúzések. A politikai döntéshozatal folyamata (Hruscsov fellépése -Tézisek - vita és jóváhagyás - törvény) lassan a végéhez közeledett, már csak egy formális, lezáró esemény volt hátra.

\section{Az ÁtAlAKítás LEGITIMÁcióJA: AZ SZKP XXI. KONGRESSZUSA (1959. JANUÁR-FEBRUÁR)}

A pártkongresszus a többi szocialista országban, később lezajlott átalakítási folyamatokban is a legitimáló-jóváhagyó szerepet töltötte be. Az SZKP rendkívüli, XXI. kongresszusának jegyzőkönyve (1959. 61-71. 625-626. o.) és az ezt megelőző munkálatok (Hruscsov, 1958c) alapján ismertetem a hétéves terv vonatkozó részét, az oktatási reform gazdasági-politikai hátterét. ${ }^{6}$. Az átalakítás ideológiai megalapozása természetesen Leninre hivatkozott: „minden irányban fejlett és minden irányban iskolázott” emberek nevelése a cél, a továbbiakban a Téziseket ismételte meg az előterjesztés. Az 1959 és 1965 közötti tervidőszakra ütemezte a pártvezetés a nyolc évre felemelt tankötelezettség bevezetését, amihez új tanmúhelyeket kellett biztosítani, a 10 osztályos iskolák (felső osztályok) átszervezéséhez pedig városi, falusi „munkás-középiskolák” hálózatának létrehozása vált szükségessé, illetve a középiskolák számát is bővíteni kellett, hogy be tudják fogadni a munka mellett továbbtanuló diákokat.

\footnotetext{
${ }^{6}$ A közoktatási tervezés fogalma ebben az időben honosodott meg az UNESCO regionális konferenciáinak köszönhetően (Temesi, 1962)
} 
Hruscsov kongresszusi előterjesztésében cáfolta azokat a külföldi véleményeket („Hadd károgjanak ezek a jövendőmondók (ti. a nyugati újságírók)...”), melyek szerint a Szovjetuniónak nincs elegendő munkaereje és ezért van szükség a fiatalság bevonására a munkába. ${ }^{7}$ Oktatás és termelőmunka összekapcsolását a távlati tervek aspektusából indokolta meg a fótitkár: a szocializmusból kommunizmusba való átmenet, a kommunizmus anyagi megalapozásának része a reform, a folyamatban Hruscsov külön hangsúlyozta a közösségi nevelés és politechnika erkölcsi aspektusait (a munka szeretete, mint az új szocialista ember típusának meghatározó jellemzője). A kongresszuson elfogadott határozat tartalmazta az intézmények extenzív fejlesztésének számait (például 2300000 szakembert kellett a szovjet főiskoláknak kinevelniük hét év alatt, szemben az előző hét év 1700 000-es adatával), de hasonlóan a korábbi tervezetekhez, nem nagyon körvonalazta a politechnikai oktatás/gyakorlati képzés mibenlétét, technikai részleteit és megvalósítását - ennek feladata a neveléstudományra és a gyakorló pedagógusokra maradt.

A 3 ÉVES ÁLTALÁNOSAN KÉPZÓ ÉS POLITECHNIKAI ISKOLA ORATERVE, MELYBEN AZ OKTATÁS A TERMELÓ MUNKAVAL OSSZEKAPCSOLVA FOLYIK: (NAPPALI)

\begin{tabular}{|c|c|c|c|}
\hline \multirow{2}{*}{ Tantárgyak } & \multicolumn{3}{|c|}{ Órák száma } \\
\hline & $I X$ & $X$ & $X I$ \\
\hline 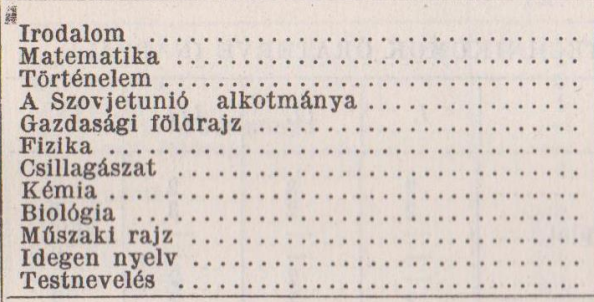 & $\begin{array}{l}3 \\
4 \\
2 \\
- \\
4 \\
2 \\
3 \\
2 \\
2 \\
2\end{array}$ & $\begin{array}{l}3 \\
4 \\
3 \\
2 \\
4 \\
1 \\
3 \\
\\
2 \\
2\end{array}$ & $\begin{array}{l}3 \\
4 \\
4 \\
2 \\
2 \\
2 \\
2 \\
\\
3 \\
2\end{array}$ \\
\hline & 24 & 24 & 24 \\
\hline 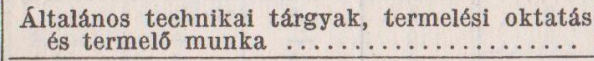 & 12 & 12 & 12 \\
\hline Fakultatív tárgyak $\ldots \ldots \ldots \ldots \ldots \ldots \ldots \ldots$ & $\begin{array}{r}36 \\
2\end{array}$ & $\begin{array}{r}36 \\
2\end{array}$ & $\begin{array}{r}36 \\
2\end{array}$ \\
\hline
\end{tabular}

1. kép

A szovjet középiskola kísérleti óraterve az 1959/60. tanévtől (Jóború, 1961. 99. o.)

Az 1. kép a megvalósulás egy formáját mutatja be, az általánosan képző, politechnikai iskola példáján, ami tulajdonképpen a mi középiskolánknak feleltethető

\footnotetext{
${ }^{7}$ Egy 1958. november 16-án keltezett bizalmas CIA-jelentés szerint (Memorandum. . , 1958) a 7 éves terv 11,5 milliós munkaerő-növekedését a természetes utánpótláson kívül az oktatási reform és a mezőgazdaságból való átirányítás fogja biztosítani a szovjet vezetés számításai szerint.
} 
meg. A legfeltûnőbb a politechnikai tárgyak túlsúlya az óraterhelésben, hiszen az összes óra egyharmadát adja a termeléssel összefüggő elméleti és gyakorlati tárgyak száma - a városi iskolákban ipari, a falusi intézményekben mezőgazdasági jelleggel. Az oktatás és munka váltakozásának rendjét nem határozták meg központilag, így a helyi igényekhez (kolhozokhoz, vállalatokhoz) alkalmazkodva lehetett tanterveket létrehozni. A szakmai képzés színvonala nem érte el a szakmunkás-képzés szintjét, ezért ezt szakmai előképzésnek, vagy általános technikai képzésnek nevezték, szemben a négy éves technikumok magasabb termelési óraszámával és az esti iskolák példájával, ahol a hallgatók már eleve dolgoztak (Jóború, 1961. 99-102. o.). A háromfajta középfokú iskolatípus tehát más-más módon kapcsolta össze az oktatást a termeléssel, ez a fajta differenciálódás az 1961-es magyar iskolareformra is jellemző volt (5+1-es rendszerú gimnázium, szakközépiskola, szakmunkásképző iskola).

\section{BEFEJEZÉS}

Az így létrejövő iskolai szerkezet egyszerre próbált ellentétes irányoknak megfelelni és azokat kibékíteni: a középfokú oktatás expanzióját (pedagógiai-szakmai szempont) a munka melletti képzési formákkal, az eredeti koncepciót redukálva vélték megvalósíthatónak, míg a gazdaságtervezői-politikai oldal által preferált munkaerő-piaci igényeket a gyors munkába állással és a helyi igényeknek megfelelő, praktikus politechnikai készségek elsajátításával, begyakorlásával oldották meg (DeWitt, 1961. 16. o.). A szükségszerú kompromisszum természetesen mindkét irány igényeit sérthette és számos problémát hordozott magában. A helyzet azonban ennél még bonyolultabb volt. Az akadémiai-pedagógiai oldalon belül is voltak ellentétek az átalakítás elkötelezett hívei és az óvatosabb bevezetés hívei között, ${ }^{8}$ továbbá nem szabad elfeledkezni a politika gyakori irányváltásáról, a pártvezetésen belüli harcokról.

Nem véletlen, hogy nemsokára már mentegetőznie kellett Kairovnak (1963) az oktatási reform végrehajtásával kapcsolatban: az általános képzés színvonala nem csökkent, továbbra is nyitva áll a felsőoktatás útja, egyszerre képes a szovjet iskola teljesíteni a szakképzés és a középfokú végzettség kettős feladatát, nem szükséges ehhez az iskolatípusok differenciációja. A meginduló munkálatok elsősorban tantervi-tartalmi kérdéseket érintettek, a túlterhelés csökkentésére irányultak (ld. a Szovjetunióba látogató magyar neveléstudósok beszámolóit: Ábent, 1959; Szoboszlay, 1960), csakhogy a formai javítások, átrendezések nem

\footnotetext{
${ }^{8}$ Arzsanyikov professzor, a múszaki tudományok doktora, a Szovjetunió állami díjait osztó bizottság elnöke (Hírek, 1957) például a „főiskolai gyárak" és „,tanulóüzemek" létrehozása mellett szállt síkra, ahol minimálisra csökkentik az elméletet (Szabó, 1958). Ezzel az álláspontjával szemben állt a felsőoktatás más szereplőinek véleményével, akik az elméleti megalapozást fontosabbnak tartották.
} 
érintették/nem érinthették az alapvetően ambivalens célkitûzéseket, így nem jelentettek megoldást a felmerülő problémákra.

A politechnikai oktatás ekkor kigondolt formája, a munkára nevelés iskolarendszert érintő változásai a hatvanas évek közepére kudarcot vallottak (vagy eufémisztikusabb formában: „„.. nem jártak átütő sikerrel”, ld. Köte, 1979. 192) ami döntő módon befolyásolta a reform későbbi megítélését. A sikertelenség okai között volt az anyagi fedezet hiánya, az egymást keresztező, ellentmondásos célok és koncepciók okozta zavar (Kalmár, 2014. 204. o.), továbbá az érintett szereplők (szülők, tanárok, diákok és a munkaerő-piac) egy részének ellenállása - ez azonban már egy másik történet. Nem véletlen, hogy az iskolareformról egy szó sem szerepel Hruscsov terjedelmes önéletrajzában (Crankshaw, 1970, részletek magyarul: Hruscsov, 1990), valamint tanácsadója róla írott könyvében (Burlatsky, 1991). A további kutatásoknak tisztáznia kell a többi szocialista országban végbement változások jellegét, a Szovjetunióval való hasonlóságokat és különbségeket, ami a magyar oktatástörténet jobb megértéséhez is hozzásegíthet minket.

\section{IRODALOM}

Ábent Ferenc (1958a): Az általános és politechnikai képzés tartalmi problémáival foglalkozó értekezlet. Pedagógiai Szemle, 8. 1. szám, 80-83.

Ábent Ferenc (1958b): Új elgondolások az iskolarendszer megreformálására. Pedagógiai Szemle, 8. 12. szám, 1193-1198.

Ábent Ferenc (1959): A szovjet közoktatás átszervezésének néhány tapasztalata. Pedagógiai Szemle, 9. 9. szám, 859-870.

Bori István és Tihanyi Ferenc (1957): A technikai múveltség szerepe néhány nyugati ország iskolarendszerében. Köznevelés, 13. 11-12. szám, 253-255.

Burlatsky, F. (1991): Khruschev and the First Russian Spring. The Era of Khruschev Through the Eyes of His Advisor. Macmillan, New York.

Coumel, L. (2009): The Scientist, the Pedagogue and the Party Official: Interest Groups, Public Opinion and Decision-making in the 1958 Education Reform. In: Ilic, M. és Smith, J. (szerk., 2009): Soviet State and Society under Nikita Khruschev. Routledge, Abingdon - New York, 66-86.

Crankshaw, E. (1970): Khruschev Remembers. Little, Brown and Company, Boston, Toronto.

Csoma Vilmos (1958): A XXI. Nemzetközi Nevelésügyi Konferencia. Köznevelés, 14. 17. szám, 395-397.

DeWitt, N. (1961): Education and Professional Employment in the U.S.S.R. National Science Foundation, Washington.

Faragó László (1957): A politechnikai képzés időszerû feladatai és problémái a szovjet pedagógiában. Köznevelés, 13. 9. szám, 207-209. 
Faragó László (1958): Az OSZSZSZK Neveléstudományi Akadémiájának 1958. évi kutatási terve. Köznevelés, 14. 14. szám, 335-338.

Feljegyzés. Hruscsov elvtárs akadémiai beszédének visszhangja. MNL OL, $288 \mathrm{f}$. 33/1958/3. ő. e. MSZMP KB TKO, Szerényi Sándor, 1958. április 11.

Gorjunov, D. P. (1959): Barátok öröme. Népszabadság, 17. 1959. január 4. 11.

Hírek (1957). Új Szó, 10. 1957. november 10. 2.

Holmes, R, Read, G. H. és Voskresenskaya, N. (1995): Russian Education: Tradition and Transition. Garland Publishing, London - New York.

Hruscsov, Ny. S.z. (1958a): Valamennyi munkás- és kolhozparaszt-fiatal végezze el a középiskolát. Befejeződött a Komszomol XIII. kongresszusa. Népszabadság, 16. 1958. április 20. 6.

Hruscsov, Ny. Sz. (1958b): Feljegyzései a szovjet népoktatás rendszerének fejlesztéséról, az iskola és az élet kapcsolatairól. Népszabadság, 16. 1958. szeptember 23. 6 .

Hruscsov, Ny. Sz. (1958c): A Szovjetunió 1959-1965. évi népgazdaságfejlesztési ellenőrző számai. N. Sz. Hruscsov elvtárs beszámolójának tézisei a Szovjetunió Kommunista Pártja XXI. kongresszusára. Népszabadság, 16. 1958. november 18. 5-8.

Hruscsov, Ny. Sz. (1990): Szemben a zsarnokkal. Hruscsov emlékezik. Leopárd Kiadó, Budapest.

Jóború Magda (1958): A sèvres-i konferenciáról. Pedagógiai Szemle, 8. 7-8. szám, 730-738.

Jóború Magda (1961): Élet és iskola. Gondolat, Budapest.

Kairov, I. A. (1958): Basic Questions Relating to School Reorganization. Soviet Education, 1. 3. szám, 5-12.

Kairov, I. A. (1963): The Reorganization of General Secondary Education. In.: Shapovalenko, S. G. (ed.): Polytechnical Education in the U.S.S.R. UNESCO, Paris-Amsterdam, 55-70.

Kairov, I. A., Goncsarov, N. K., Jeszipov, B. P. és Zankov, L. V. (1959): Pedagógia. Tankönyvkiadó, Budapest.

Kalmár Melinda (2014): Történelmi galaxisok vonzásában. Magyarország és a szovjetrendszer, 1945-1990. Osiris, Budapest.

Kálmán György (1958): A szovjet iskolarendszer reformtervezetéről. Köznevelés, 14. 21. szám, 493-494.

Köte Sándor (1979): A szocialista munkaiskola kezdetei, 1917-1920. Akadémiai Kiadó, Budapest.

Lilge, F. (1959): Impressions of Soviet Education. International Review of Education, 5. 1. szám, 11-27.

Medlin, W. K. (1958): Soviet Pedagogical Academy and the New School Plans. Comparative Education Review, 2. 2. szám, 12-14.

Megkezdődött a vita a Szovjetunióban az iskolarendszer átszervezéséről (1958). Népszabadság, 16. 1958. november 20. 10. 
Memorandum for Director of Central Intelligence: Khruschev's Theses on the SevenYear Economic Plan. (1959-1965). 16, November, 1958. Online: http://www. foia . cia.gov/sites/default/files/document_conversions/89801/DOC_0000234156. pdf, 2015. 04. 27.

Mitter, W. (1981): Das amerikanische und das sowjetische Schulwesen. In: Twellmann, W. (szerk., 1981): Handbuch Schule und Unterricht. Band 3, Pädagogischer Verlag Schwann, Düsseldorf, 521-540.

Nagy Sándor (1958): Iskolarendszertani és didaktikai kutatások a Szovjetunióban. Pedagógiai Szemle, 8. 9. szám, 805-817.

Osztrotyitanov, K. (1958): A kommunizmus építésének elméleti problémái a Szovjetunióban. Népszabadság, 16. 1958. július 5. 2-3.

Ross, L. W. (1960): Some Aspects of Soviet Education. The Journal of Teacher Education,11. 4. szám, 539-552.

Rudman, H. C. (1959): De-emphasis of Academics in the USSR. The Elementary School Journal, 59. 5. szám, 253-257.

Sáska Géza (2008): Régi és új szólamok értelmezése az 1945 utáni pedagógiai kánonban. Új Pedagógiai Szemle, 58. 11-12. szám, 161-187.

Setényi János (1992): Harc a középiskoláért, Kísérletek az egységes középiskola megteremtésére az 1945 utáni Európában. Educatio, Budapest.

Simon György (1960): A tudományos-múszaki forradalom társadalmi következményei. Közgazdasági Szemle, 7. 5. szám, 619-624.

Szabó István (1958): A Szovjetunió Legfelsőbb Tanácsának üléséről. Népszabadság, 16. 1958. december 23. 6.

Szebenyi Péter (1997): Tagoltság és egyesítés - tananyagszabályozás és iskolaszerkezet. Magyar Pedagógia, 97. 3-4. szám, 271-302.

Szkatkin, M. N. (1958): Hogyan fejlődik a politechnikai oktatás elmélete és gyakorlata. Köznevelés, 14. 16. szám, 377-378.

Az SZKP XIX. kongresszusának anyaga (1952), Szikra, Budapest.

Az SZKP XX. kongresszusa (1956), Szikra, Budapest.

Az SZKP XXI. kongresszusa (1959), Kossuth, Budapest.

Az SZKP Központi Bizottságának és a Szovjetunió Minisztertanácsának tézisei az iskola és az élet kapcsolatának erôsítéséről és a szovjet közoktatási rendszer továbbfejlesztéséról. Népszabadság, 16. 1958. november 19. 7.

Szoboszlay Miklós (1960): Az iskolareformmal kapcsolatos tantervi kérdések a Szovjetunióban. Pedagógiai Szemle, 10. 12. szám, 1111-1120.

Szovjetunió. Az elemi, hétéves és középiskola 1957/58. évi kísérleti óraterve (1958). Köznevelés, 14. 4. szám, 92.

Sztálin, I. (1952): A szocializmus közgazdasági problémái a Szovjetunióban. Társadalmi Szemle, 7. 10, 889-946.

Temesi Alfréd (1962): Közoktatási reform és közoktatási tervezés. Pedagógiai Szemle, 12. 9. szám, 798-810.

UNESCO (1958a): Curriculum Revision and Research. UNESCO, Paris. 
Pedagógiatörténeti Szemle • 2. évf. 1-2. sz. 23-39. o. • 2016

DOI:10.22309/PTSZEMLE.2016.1.2

UNESCO (1958b): International Yearbook of Education. Vol. XX. UNESCO, Paris - Geneva.

Zibolen Endre (1958): Iskolarendszeri típusok. Köznevelés, 14. 9. szám, 202-204. 


\title{
Az „Európa-kép” tartalmi vizsgálata a dualizmus kori középiskolai egyetemes történelemtankönyvekben
}

\author{
MolnÁR-KovÁcs ZsófiA
}

Pécsi Tudományegyetem Neveléstudományi Intézet

\begin{abstract}
Az „Európa-kép” szimbolikus, kettős értelmezéssel bíró fogalom. Tágabb értelemben történeti, földrajzi, gazdasági, politikai, kulturális entitás, konstrukció, szúkebb értelemben pedig jelenti/jelentheti a képeken, térképeken megjelenített Európát, az Európáról kialakult nézeteket ${ }^{1}$, melyet jelen tanulmányban a tankönyvkutatás keretein belül, a történelemtankönyvek vonatkozásában közelítünk meg.
\end{abstract}

\section{A KUTATÁSI TÉMA MEGJELÖLÉSE, RELEVANCIÁJA}

A dualizmus kori középiskolai történelemtankönyvek „Európa-kép”-ének vizsgálata több szempontból is indokolt. Az „Európa-kép” átfogó, a 19. század második harmadáig, a magyar közoktatásügy korszerúsítésének megkezdéséig, a magyar polgári iskolaügy alapjainak megteremtéséig visszatekintő feldolgozása a történelemtankönyvek vonatkozásában még nem történt meg. A hazai szakirodalomban az 1990-es évek elejétől jelentek meg az európaiságot, a tankönyvi „Európa-kép”-et vizsgáló, illetve azt fókuszba állító szaktanulmányok, melyek - Szabolcs Ottó 1980-as években végzett vizsgálódásaitól eltekintve (lásd Európa-kutatás, 2006) - mindenekelőtt a rendszerváltás utáni tankönyvek elemzését helyezték előtérbe (lásd például Dárdai, 2002; Fischerné Dárdai, 2011, 2012; Domokos, 2002; M. Császár, 2004).

Mészáros István - ezzel párhuzamosan - az Európaiság, magyarság régi tankönyveinkben címú szakcikkében szintén megfogalmazza a sürgető igényt, mely szerint „az 1945 előtti négy évtized hazai tankönyvtermése már a magyar neveléstörténet részét alkotja. Tárgyilagos, előítéletmentes, alapos tartalmi elemzésük [...] halaszthatatlanul fontos feladat." (Mészáros, 1991. 11. o.) Mindezt az is alátámasztja, hogy „A tankönyvkutatások az utóbbi évek neveléstudományi

\footnotetext{
${ }^{1}$ Az Európáról szóló történetfilozófiai diskurzusok nem képezik jelen vizsgálat tárgyát, ugyanakkor szükséges megemlítenünk, hogy „mind történetileg, mind pedig a jelenben voltak és vannak olyan diskurzusok, amelyek azt érintik vagy járják körül, hogy „micsoda Európa”, hogy szükség lenne „Európára”, illetve mit jelent az „európaiság”." (Horváth, 2009. 112. o.; lásd még Penke, 2000; Mollat du Jourdin, 1996)
} 
vizsgálódásainak sorában egyre hangsúlyosabb módon jelennek meg, utat nyitva ezzel olyan szempont- és összefüggésrendszerek elemzéséhez, illetve újraértelmezéséhez, melyek tovább gazdagíthatják az iskola, a nevelés-oktatás világa történéseinek feltárását." (Gróz, 2005. 199. o.) Az 1990-es évek elejétől a nemzetközi fórumokon is gyakran szentelnek figyelmet az európaiság témakörének, illetve az ezzel kapcsolatos tankönyvkutatásoknak (lásd Dárdai, 2002. 73. o.), ugyanakkor a nemzetközi viszonylatban - a nemzeti, illetve a közös identitás megjelenítése kapcsán - már az 1950-es években a tankönyvek felé fordultak.

A dualizmus időszakára fókuszáló, napjainkig közzétett tankönyvkutatások és publikációk mindenekelőtt a történelemtankönyvek, a népiskolai olvasókönyvek és a pedagógiai szakkönyvek vizsgálatával foglalkoznak. Jelen kutatás szintén e sort gazdagítja. A korszak tankönyveinek elemzését illetően behatóbb vizsgálatokat folytattak: Adamikné Jászó Anna (olvasástanítás-történet), Dombi Alice (19. századi tankönyvek, tankönyvírók), Farkas Mária (olvasókönyvek, népiskolai történelemtankönyvek történelemszemlélete) Gróz Andrea (fegyelemre nevelés kérdése a pedagógiai szakkönyvekben), Méreg Martin (Schultz Imre tankönyvírói munkássága), Molnár-Kovács Zsófia (középiskolai történelemtankönyvek és azok változatai, tankönyvszerzői életutak) és Nóbik Attila (neveléstörténeti tankönyvek Rousseau-képe, kánonképzés). (lásd többek között Adamikné Jászó, 1990; Dombi, 2015; Farkas, 2008; Gróz, 2007; Méreg, 2015; Molnár-Kovács, 2016; Nóbik, 2010) Ugyanakkor a korabeli hazai történelemtankönyvek kapcsán megjelent publikációk és analitikus szemléletet tükröző tankönyvkutatások száma kevésnek mondható.

Ma az európaiság identitásunk meghatározó eleme, fontos tehát tudnunk, hogy ennek a koncepcionális alapjai, (oktatás)történeti gyökerei hova nyúlnak vissza a dualizmus korában és a dualizmus kori tankönyvek tartalmaznake erre vonatkozó utalásokat. E helyütt - e gondolati ív alátámasztására érdemes megemlíteni Gerhard Seewann professzor gondolatait, aki maga is úgy fogalmaz, hogy „A reformkor óta folyik elvi síkú vita Magyarországon a magyar identitásról, illetve arról, hogy hol legyen Magyarország helye Európában és ezzel összefüggésben milyen utat válasszon az ország, illetve a nép a mindenkori politikai-történelmi szituációban." (Seewann, 2009. 101. o.)

\section{A KUTATÁS CÉLJA ÉS A KUTATÓI KÉRDÉSEK}

A vizsgálat célja a dualizmus kori középiskolai történelemtankönyvek „Európakép"'-ét meghatározó állandó és változó tendenciák és hangsúlyok feltárása.

A központi kutatói kérdés a következő: Hogyan ábrázolták Európát, az európaiságot a tankönyvek, tehát milyen "Európa-kép” bontakozik ki az elemzés alá vont dualizmus kori magyar középiskolai egyetemes történelemtankönyvekben?

Az ehhez kapcsolódó kutatói kérdések pedig a következők:

1. Milyen arányban jeleníti meg a tankönyvi textus és a tankönyvi illusztrációs bázis Európát, az európai történelmi szálakat a vizsgált fejezetek, alfejezetek tartalmához viszonyítva? 
2. Hogyan határozható meg az „európaiság”, illetve „Európa” fogalma a vizsgálat alá vont dualizmus kori magyar középiskolai egyetemes történelemtankönyvekben (a vizsgált fejezetekben, alfejezetekben)?

3. Változtak-e, s ha igen, mennyiben változtak a vizsgált időszakban az „Európakép"'-et befolyásoló tankönyvi tartalmak?

\section{A KUTATÁs MÓdSZEREI}

A vizsgálat elemző egységének elkészítése előtt - ugyanakkor a vizsgálat szerves részeként - a teljesség igényével feltártuk, valamint rendszereztük az „Európakép” és „,tankönyvkutatás” fogalmak kapcsolódási pontjait, vizsgálati lehetőségeit és eredményeit a témáról megjelent szakirodalom alapján. A szakirodalomelemzés főként a hazai szakirodalmi bázisra fókuszált, azonban a nemzetközi (mindenekelőtt európai) kutatások ezredfordulót követően közzétett eredményeire is rápillantottunk.

A szintézis során nyilvánvalóvá vált, hogy a hazai (fóként történelem) tankönyvi „Európa-kép”-vizsgálatok, illetve azok publikálása a 20. század végén, az 1990-es évektől került az érdeklődés homlokterébe. A számba vett vizsgálati eredmények mindegyike felhívta a figyelmet az Európa-definíció tankönyvi hiátusára. Emellett a sokrétú kutatói törekvések láttatni engedték a téma vizsgálatának módszertani lehetőségeit, elemzési tapasztalatait, ezáltal pedig - közvetett módon - különböző opciókat kínáltak fel a témakör további kutatásához. A nemzetközi kutatói színtér gazdag bázisából merítkező „Európa-kép”-vizsgálatok tágabb perspektívába helyezték a hazai kutatások kézzelfogható eredményeit, ezáltal meghatározó szerepet játszanak/játszhatnak a jövőbeli kutatói irányvonalak tudatos(abb) kijelölésében is. (erről bővebben lásd Molnár-Kovács, 2014)

A dualizmus kori magyar középiskolai egyetemes történelemtankönyvek „Európa-kép”-ét a tartalomelemzés módszerével vettük közelebbről szemügyre. Ennek oka, hogy „a tartalomelemzés egy olyan interdiszciplináris módszer, amelynek segítségével a közlemények (gyakorlatilag a legtöbbször szövegek) rejtett, tehát nyíltan, expressis verbis ki nem fejezett tulajdonságai is feltárhatóak." (Antal, 1976. 44-45. o.)

Így a manifeszt tankönyvi európaiság mellett a látens tartalom is megismerhető (lásd Babbie, 2008. 357-358. o.). A II. világháborút követően előtérbe kerülő metódus alkalmazása a tankönyvek vonatkozásában sem újkeletú, s - ahogy Szabolcs Éva is rávilágít - „Pedagógiai alkalmazása kezdetben azt jelentette, hogy a tankönyvekben tetten érhető értékválasztásokat igyekeztek kimutatni a segítségével." (Szabolcs, 2004. 331. o.).

\section{A KUTATÁS FORRÁSAI}

A kutatás elsődleges forrásait a magyar dualizmus kori középiskolai egyetemes történelemtankönyvek egy sajátos csoportja jelenti: a VII. osztály számára készített 15 db történelemtankönyv, illetve annak 1815 utáni fejezetei, alfejezetei. E tankönyvek 
az újkor történelmének 1648-tól a ,jelenkorig” tartó időszakát tárgyalják. Az 1815 utáni világtörténelmet taglaló tankönyvi részek kezdő kronológiai éve azonos (1815), ugyanakkor az említett vagy ábrázolt utolsó (záró) kronológiai adat (év) a vizsgálat alá vont tankönyvek különböző kiadásainak előrehaladtával párhuzamosan halad időrendben előre.

Ebből (is) kifolyólag az 1815 utáni fejezetek, alfejezetek kiválasztása és vizsgálata lehetővé teszi a dualizmus kori középiskolai történelemtankönyvekben tárgyalt vagy ábrázolt ,,jelenkor” „Európa-kép”-ének változó és állandó tendenciáit megragadó fejlődési ív megrajzolását.

A vizsgálat során reprezentatív elemzés megvalósítására törekedtünk, ennek érdekében pedig az alábbi kitételek mentén határoztuk meg a tankönyvek kiválasztásának kritériumait:

- középiskolai (gimnáziumi és reáliskolai) tankönyvek vizsgálata,

- egyetemes történelemtankönyvek vizsgálata,

- VII. osztály számára készített tankönyvek vizsgálata,

- minden rendelkezésre álló kiadás vizsgálata,

- segédkönyvek vizsgálatától való eltekintés.

A vizsgálat tehát e paraméterek mentén összesen 15 darab tankönyv elemző áttekintését valósította meg, melyek szerzőinek nevét, a kiadás évét és a tankönyv címét e helyütt is megadjuk: ${ }^{2}$

1. Mangold Lajos (1885): Világtörténelem. (a továbbiakban: Mangold, 1885)

2. Mangold Lajos (1891): Világtörténelem. (a továbbiakban: Mangold, 1891)

3. Mangold Lajos (1902): Világtörténelem. (a továbbiakban: Mangold, 1902)

4. Márki Sándor (1903): Egyetemes történelem. (a továbbiakban: Márki, 1903)

5. Mika Sándor (1904): Világtörténet. (a továbbiakban: Mika, 1904)

6. Mika Sándor (1912): Világtörténet. (a továbbiakban: Mika, 1912)

7. Sebestyén Gyula (1906): Egyetemes történet. (a továbbiakban: Sebestyén, 1906)

8. Szigethy Lajos (1903): Egyetemes történet. (a továbbiakban: Szigethy, 1903)

9. Szölgyémy János (1914): Világtörténet. (a továbbiakban: Szölgyémy, 1914)

10. Ujházy László (1904): Egyetemes történelem. (a továbbiakban: Ujházy, 1904)

11. Ujházy László (1913): Egyetemes történelem. (a továbbiakban: Ujházy, 1913)

12. Varga Ottó (1904): Világtörténet. (a továbbiakban: Varga, 1904)

13. Vaszary Kolos (1904): Világtörténelem. (a továbbiakban: Vaszary, 1904)

14. Vaszary Kolos (1912): Világtörténelem. (a továbbiakban: Vaszary, 1912)

15. Takáts György (1917): Történelem. (a továbbiakban: Takáts, 1917)

E tankönyvek sorában egy leányközépiskolai tankönyv is helyet kapott (lásd a fenti lista 15. tétele), mely a felső leányiskolák, a leánygimnáziumok és a felső kereskedelmi leányiskolák III. osztály számára készült (Takáts, 1917). A leányközépiskolai tankönyv vizsgálata - annak ellenére, hogy az iskolatípus és az évfolyam nem feleltethető meg egy az egyben a fiúközépiskolák esetében

\footnotetext{
${ }^{2}$ A vizsgálat alá vont 15 db történelemtankönyv a budapesti Oktatáskutató és Fejlesztő Intézet Pedagógiai Könyvtár és Múzeum Tankönyvtárában található.
} 
rögzített paramétereknek - összevetési alapot kínált, illetve betekintést engedett a leányközépiskolák dualizmus kori egyetemes történelemtanításába.

A másodlagos forrásokat tekintve lehetőség adódott a hazai tankönyvi „Európa-kép”-vizsgálatok kutatási előzményeinek, szakirodalmi forrásainak teljeskörû́ elemző áttekintésére, szisztematikus feldolgozására. A hazai tankönyvi szakirodalom - második világháborút követően gyarapodó - sokrétú tematikus csomópontjait áttekintve láthatóvá vált, hogy a magyarországi - mindenekelőtt történelmi tárgyú - tankönyvek „Európa-kép”-ének vizsgálata, szakirodalmi tárgyalása a 20. század végén, a rendszerváltást követően került előtérbe. Az 1990-es évek elejétől fogva a tankönyvi „Európa-kép”-kutatás - a tudományos tankönyvelemzések sajátos szegmenseként - megjelent a magyar tankönyvi szakirodalom egyre szélesebb spektrumot felölelő palettáján.

A hazai kutatások, közzétett vizsgálati eredmények közös vonása mindenekelőtt az Európa-fogalom definiálatlanságának tudatosítása a fókuszba került történelem- és földrajz tankönyvek vonatkozásában. Emellett láthatóvá vált a téma vizsgálatához elengedhetetlen - egymást kiegészítő kvantitatív és kvalitatív módszereket egyaránt alkalmazó - módszertani háttér, mely az eredmények árnyalt értelmezését segíti elő.

A feltárt nemzetközi „Európa-kép”-vizsgálatok egyértelmúvé teszik a magyar kutatói törekvések relevanciáját, a hazai eredmények illeszkedését a nemzetközi trendekbe, egyúttal lehetőséget, igényt és alapot teremtenek a további - tematikusan, térben és időben kiszélesedő - tankönyvvizsgálatok lefolytatásához. (bővebben lásd Molnár-Kovács, 2014)

\section{A TANKÖNYVEK ELEMZÉSE}

Az 1815 utáni fejezetek, illetve alfejezetek az ún. legújabb kor világtörténelmi áttekintésére vállalkoznak, mely mindenekelőtt - a tankönyvi fejezetek, alfejezetek címe alapján - az alkotmányos, nemzeti és szociális küzdelmek tárgyalását helyezi a fókuszba (lásd Mangold, 1885. 188-212. o.; Mangold, 1891. 229-274. o.; Mangold, 1902. 156-205. o.; Márki, 1903. 134-173. o.; Mika, 1904. 124-160. o.; Mika, 1912. 140-180. o.; Sebestyén, 1906. 178-222. o.; Szigethy, 1903. 138-176. o.; Szöloyémy, 1914. 106-139. o.; Ujházy, 1904. 177-235. o.; Ujházy, 1913. 123-167. o.; Varga, 1904. 145-175. o.; Vaszary, 1904. 136-171. o.; Vaszary, 1912. 125-163. o.; Takáts, 1917. 106-120. o.).

A tankönyvek mintegy fele ugyanakkor külön egység keretén belül szót ejt a legújabb kor múvelődéstörténeti viszonyairól (lásd Mangold, 1885. 213-228. o.; Mangold, 1891. 274-277. o.; Mangold, 1902. 205-207. o., 210. o.; Márki, 1903. 173-197. o.; Szölgyémy, 1914. 140-143. o.; Vaszary, 1912. 163-183. o.; Takáts, 1917. 120-121. o.), továbbá a vizsgált kötetek mintegy 3/4-e egy külön fejezetben politikai földrajzi vonásokat is tárgyal (lásd Mangold, 1902. 214-262. o.; Márki, 1903. 198-250. o.; Mika, 1904. 169-248. o.; Mika, 1912. 189-259. o.; Sebestyén, 1906. 223-262. o.; Szigethy, 1903. 180-254. o.; Szölgyémy, 1914. 145-191. o.; Ujházy, 1904. 236-307. o.; Ujházy, 1913. 167-220. o.; Vaszary, 1904. 185-236. 
o.; Vaszary, 1912. 189-232. o.). Jelen vizsgálat során azonban e két egység vizsgálatától eltekintettünk.

A tartalomelemzés előkészítéseként - ugyanakkor egy iránymutató vizsgálati fázisként - a fókuszba emelt tankönyvi fejezetek/alfejezetek oldalait először áttekintettük aszerint, hogy Európa, az Európán kívüli világ, vagy az Európán kívüli világ Európával közös történelmi említését, ábrázolását valósítja-e meg nagyobb oldalszámban, illetve arányban ${ }^{3}$.

A kibontakozó eredmények alapján megállapítható Európa világtörténelmének tankönyvi dominanciája; kiemelkedően nagyarányú önálló ábrázolása a vizsgált tankönyvi fejezetekben egyértelmúen látható. Százalékos megoszlásban mindez azt jelenti, hogy a 15 db tankönyv vizsgálat alá vont (al)fejezeteiben átlag 93 \%-ot tesz ki Európa történelme ${ }^{4}$, mely az egyes kötetekre vetítve 79,5-100 \% közötti tankönyvi reprezentációt jelent.

Az 1815 utáni tankönyvi fejezetek, alfejezetek tartalomelemzésének lépései a következőképpen foglalhatók össze:

1. A kutatói célok és kutatói kérdések alapján a kutatási források és a vizsgálati módszer(ek) meghatározása,

2. Tartalmi főkategóriák körvonalazása és rögzítése; a főkategóriák átfogó kvantitatív elemzése,

3. „Európa” mint tartalmi főkategória részletes vizsgálata; az „Európá”-val kapcsolatos kifejezések, gondolati ívek összegyújtése, rendszerezése,

4. „Európá”-val kapcsolatos szókapcsolatok vizsgálata; hívószavak indukálása,

5. A hívószavak kategorizálása; tartalmi alkategóriák megalkotása,

6. A hívószavakra építve a tartalmi alkategóriák vizsgálata,

7. Összegzés - a vizsgálati eredmények rögzítése az „Európa” mint tartalmi főkategóriára vonatkozóan.

A továbbiakban a 2-7. vizsgálati lépéseket részletesen is feltárjuk, ismertetjük. $\mathrm{Az}$ 1. pontra azonban az alábbiakban nem térünk ki, melynek oka, hogy a kutatói célok, kutatói kérdések, a kutatás forrásai és a vizsgálati módszerek a tanulmány bevezetô részében már bemutatásra kerültek.

\section{TARTALMI FŐKATEGÓRIÁK KÖRVONALAZÁSA ÉS RÖGZÍTÉSE; A FŐKATEGÓRIÁK ÁTFOGÓ KVANTITATÍV ELEMZÉSE}

A tartalmi főkategóriák felállítása során több szempont is mérlegelésre került. Egyrészt figyelembe kellett venni, hogy a meghatározásra kerülő főkategóriák azonos kategóriaszintet képezzenek, tehát ne merüljön fel az alá-fölérendeltségi viszony lehetősége a főkategóriák között. Másrészt pedig az „európaiság”, illetve az „Európa-kép”-vizsgálat aspektusának mélyebb elemzési lehetőségét és

\footnotetext{
${ }^{3}$ Az oldalszámok megállapítása során kerekítést alkalmaztunk. 0-0,4 oldal között 0 oldalra, míg 0,5-1 oldal között 1 oldalra kerekítettük a tankönyvi oldalszámokat.

4 Az Európán kívüli világ átlagban 1,4%-ot, míg az Európán kívüli világ Európával közös említése, ábrázolása 5,6 \%-ot tesz ki a vizsgált tankönyvi egységekben.
} 
igényét előre vetítve „Európa” mint alapveto foḱkategória rögzítése kézenfekvő és tulajdonképpen evidens választásnak bizonyult.

Ebből kifolyólag a főkategóriák körvonalazása során a következő öt főkategória került meghatározásra: ${ }^{5}$

1. Európa (Európa, európai, európai-, europai, Európa-, európa-, Europe, Europa, europea, europ., Europäischer)

2. Amerika (Amerika, amerikai, Amerikai, Amerique, amerik, America)

3. Ázsia (Ázsia, ázsiai)

4. Afrika (Afrika, afrikai, sötét földrész)

5. Ausztrália (Ausztrália, ausztráliai, ausztrál, Oczeania)

A főkategóriákat először egy átfogó, valamennyi főkategóriát érintő kvantitatív elemzésnek vetettük alá. Ennek során az öt főkategóriát, illetve az azokat reprezentáló szóösszetételeket, kifejezéseket, előtagokat és rövidítéseket (lásd fentebb, a főkategóriák mögötti zárójeleket) minden egyes vizsgált tankönyvi fejezetben/alfejezetben megszámoltunk, tehát rögzítettük az előfordulások számát.

Az „Európa” főkategóriát ezen túlmenően, további lépésekben - hívószavak és alkategóriák felállítása révén - is vizsgáltuk, míg a többi főkategória („Amerika”, „Ázsia”, ,Afrika” és „Ausztrália”, tehát összefoglalóan az „Európán kívüli világ") mélyebb elemzésétől - a kutatói célokat és a kutatói kérdéseket szem előtt tartva - eltekintettünk. (Az átfogó kvantitatív elemzés eredményeit az 1. táblázat összesíti.)

Az öt főkategóriát a vizsgált 15 db tankönyv 1815 utáni fejezeteiben és alfejezeteiben összesen $727 \mathrm{db}$ kifejezés reprezentálja. Valamennyi tankönyv esetében egyértelmúen megállapítható az „Európa” főkategória előfordulásának dominanciája. A Vaszary Kolos 1912. évi történelemtankönyvéből nyert adatok például jól illusztrálják a teljes mintát - egyesével és összességében is - jellemző arányokat. E tankönyvben a vizsgálat alá volt 1815 utáni tankönyvi egységben „Európa” harmincötször, „Amerika” tízszer, „Ázsia” nyolcszor, „Afrika” háromszor, míg az „Ausztrália” főkategória egyszer jelenik meg (lásd 1. táblázat; lásd még Vaszary, 1912. 125-163. o.).

Ha az összesített eredményeket, tehát az egyes tankönyvi előfordulások összesített adatait áttekintjük, akkor világosan körvonalazódnak a teljes vizsgálati mintát meghatározó átlagszámok és átlagarányok. A 727 db (100\%) főkategória-előforduláson belül a legnagyobb számban és arányban az „Európa” főkategória van jelen 468 db (64,4 \%) megjelenéssel. Ezen túlmenően "Amerika” összesen 136 db (18,7 \%), „Ázsia” 65 db (9\%), „Afrika” 44 db (6 \%), ,Ausztrália” pedig $14 \mathrm{db}(1,9 \%)$ szóösszetétellel képviseli a további négy főkategóriát (lásd 1. táblázat).

\footnotetext{
${ }^{5}$ A főkategóriák mögött zárójelben, dőlt betűkkel valamennyi, a vizsgált tankönyvi fejezetekben/alfejezetekben szereplő, az adott főkategória elnevezését reprezentáló kifejezést, szóösszetételt, elötagot és rövidítést megadtuk.
} 
1. táblázat. A tartalmi fókategóriák előfordulása a vizsgált tankönyvek 1815 utáni fejezeteiben és alfejezeteiben $(\mathrm{db})$

\begin{tabular}{|l|l|l|l|l|l|l|}
\hline Tankönyvek & \multicolumn{5}{|c|}{ Tartalmi fókategóriák } & Összes \\
& Európa & Amerika & Ázsia & Afrika & $\begin{array}{c}\text { Auszt- } \\
\text { rália }\end{array}$ & \\
\hline Mangold, 1885 & 19 & 7 & 0 & 1 & 0 & 27 \\
\hline Mangold, 1891 & 51 & 10 & 7 & 5 & 0 & 73 \\
\hline Mangold, 1902 & 44 & 9 & 7 & 9 & 3 & 72 \\
\hline Szigethy, 1903 & 47 & 10 & 4 & 1 & 0 & 62 \\
\hline Márki, 1903 & 49 & 29 & 11 & 6 & 3 & 98 \\
\hline Vaszary, 1904 & 29 & 10 & 4 & 1 & 0 & 44 \\
\hline Mika, 1904 & 31 & 10 & 1 & 4 & 2 & 48 \\
\hline Varga, 1904 & 32 & 5 & 4 & 2 & 0 & 43 \\
\hline Ujházy, 1904 & 15 & 6 & 1 & 0 & 1 & 23 \\
\hline Sebestyén, 1906 & 28 & 6 & 4 & 1 & 0 & 39 \\
\hline Mika, 1912 & 28 & 10 & 1 & 4 & 2 & 48 \\
\hline Vaszary, 1912 & 35 & 10 & 8 & 3 & 1 & 57 \\
\hline Ujházy, 1913 & 17 & 5 & 1 & 0 & 1 & 24 \\
\hline Szölgyémy, 1914 & 32 & 9 & 11 & 7 & 1 & 60 \\
\hline Takáts, 1917 & 8 & 0 & 1 & 0 & 0 & 9 \\
\hline Összesen $(\mathrm{db})$ & 468 & 136 & 65 & 44 & 14 & 727 \\
\cline { 5 - 7 }$(\%)$ & 64,4 & 18,7 & 9 & 6 & 1,9 & 100 \\
\hline
\end{tabular}

\section{„EURÓPA" MINT TARTALMI FŐKATEGÓRIA RÉSZLETES VIZSGÁLATA; AZ „EURÓPÁ”-VAL KAPCSOLATOS KIFEJEZÉSEK, GONDOLATI ÍVEK ÖSSZEGYÛJTÉSE, RENDSZEREZÉSE}

A továbbiakban az „Európa” főkategória részletekbe menő elemzésére fókuszálunk. Ahogy fentebb már ismertettük, az „Európa” főkategória esetében is megszámoltuk a vizsgált tankönyvi (al)fejezetekben az azt megjelenítő szóösszetételeket, kifejezéseket, előtagokat és rövidítéseket, mely 468 db előfordulást jelentett. ${ }^{6}$ Ezt követően kvantitatív és kvalitatív irányú, analizáló és szisztematizáló munkafázis egyaránt következett. Ennek szellemében egyrészt figyelmet fordítottuk az „Európa” főkategória előfordulási gyakoriságának meghatározására a vizsgált tankönyvi fejezetekben/alfejezetekben egy ún. sürüségi mutató-

\footnotetext{
6 Ehelyütt meg kell jegyeznünk, hogy a 468 db „Európa” tartalmi főkategória-előfordulás vizsgálata a tankönyvi textust és a tankönyvi illusztrációs bázist egyaránt érintette, ugyanakkor a vizsgált tankönyvi egységekben összesen csupán 3 db grafikus illusztráció található, melyekben szerepel „Európa” (lásd Mangold, 1891. 250-251. o.; Mangold, 1902. 166-167. o.; Szigethy, 1903. 176. o.). Ebből kifolyólag az „Európa-kép” elmélyültebb vizuális elemzése, illetve az Európát ábrázoló képi illusztrációk - eredeti kutatói tervek között szereplő - ikonográfiai/ikonológiai elemzése nem valósul(hatot)t meg. A 3 db grafikus illusztráció a kortani/időrendi táblázatok közé tartozik, melyek a 468 db (100\%) „Európa” tartalmi főkategória-előfordulás csupán 0,6 \%-át jelenítik meg.
} 
szám ${ }^{7}$ segítségével, másrészt pedig táblázatokba rendezve, idézetek formájában összegyújtöttük azokat a gondolati íveket, tartalmi egységeket, melyekben az „Európa” főkategória megjelenik.

A kvantitatív munkafázis elvégzése során az egyes tankönyvi súrúségi mutatókat több aspektusból is rendszereztük. Egyrészt csoportosítottuk a sûrûség szerinti sorrend, másrészt a tankönyvek kiadási éve szerinti sorrend, harmadrészt pedig a szerzői ábécérend (azon belül pedig a kiadás éve) alapján. A sûrûség szerinti sorrend mentén csoportosított mutatószámok nyilvánvalóvá teszik, hogy a vizsgált tankönyvi egységekben átlagosan minden tankönyvi oldalon egyszer említik Európát, továbbá az 1891-1903 között megjelent tankönyvekben (kivéve: Mangold, 1902) a legnagyobb az „Európa” fókategória tankönyvi sûrûségi mutatója. ${ }^{8}$ Ez utóbbi megállapítást a kiadási év szerinti sorrend is megerősíti. Ugyanakkor a szerzői ábécérend esetében elmondható, hogy a kapott eredmények meglehetősen heterogén képet mutatnak, s a súrúségi mutatók alapján nem körvonalazódnak markáns tendenciák a korabeli tankönyvi „Európa-kép”-ről, annak állandó és változó jegyeiről.

A kvalitatív (előkészítő) munkafázis részeként minden vizsgálat alá vont tankönyvi egység esetében külön táblázatokban rendszereztük az „Európá”-t megjelenítő gondolati íveket (idézeteket). ${ }^{9}$

\section{„EURÓPÁ”-VAL KAPCSOLATOS SZÓKAPCSOLATOK VIZSGÁLATA; HÍVÓSZAVAK INDUKÁLÁSA}

Az előző lépésben ismertetett kvalitatív munkafázis az „Európa” főkategória elmélyültebb vizsgálatát készítette elő. Az „Európá”-val kapcsolatos kifejezések, gondolati ívek összegyújtését követően minden egyes idézet esetében az azokban előforduló, „Európá”-t reprezentáló szókapcsolatokat megvizsgáltunk. E vizsgálat két allépésben történt. Egyrészt minden gondolati ívet, szókapcsolatot áttanulmányoztunk abból a szempontból, hogy azokban megjelenik-e az „európaiság” fogalma, „Európa” konkrét definíciója.

Ennek során megállapítottuk, hogy a vizsgált tankönyvi egységek nem határozzák meg Európa fogalmát, tehát nem tesznek közzé konkrét definíciót Európáról, illetve az európaiságról. Másrészt pedig minden szókapcsolathoz, illetve szóösszetételhez egy-egy hívószót társítottunk. E hívószavak indukálása során igyekeztünk az eredeti szövegkörnyezetben szereplő kifejezést megőrizni, hívószóként is felhasználni, illetve szükség esetén - ha a szövegkörnyezet nem tette lehetővé az eredeti kifejezések hívószóként való alkalmazását, akkor -

\footnotetext{
${ }^{7}$ Mutatószám = egy oldalra jutó „Európa” tartalmi főkategória száma tankönyvenként („Európa” főkategória összesített száma a vizsgált fejezetekben, alfejezetekben / 1815 utáni vizsgált fejezetek, alfejezetek összoldalszáma)

8 A legmagasabb tankönyvi sûrû́ségi mutatóval Márki Sándor tankönyve (Márki, 1903), míg a legkevesebbel Ujházy László tankönyvi kötete (Ujházy, 1904) rendelkezik. Az első esetében minden 3/4-ed oldalon (tehát egy oldalon legalább egyszer), míg a második esetében minden negyedik oldalon tárgyalják „Európá”-t a tankönyvi (al)fejezetekben.

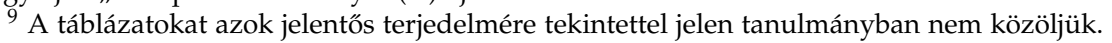


törekedtünk a jelentésben hozzájuk legközelebb eső szavak és kifejezések hívószóként való megadására. Amennyiben egy gondolati ívbe több „Európá”-val kapcsolatos kifejezés is beletartozott, azokat egy idézeten belül tüntettük fel, ugyanakkor mindegyik kifejezéshez külön sorszámot és hívószót társítottunk.

\section{A HívósZAVAK KATEGorizÁlÁSA; TARTALMI ALKATEGÓRIÁK MEGALKOTÁSA}

A hívószavak rögzítését követően megszámoltuk azokat: összesen 104 db hívószó került meghatározásra az idézetekben fellelhető „Európa” szókapcsolatok tüzetesebb vizsgálata során. A hívószavak megalkotását követően pedig arra törekedtünk, hogy a hívószavakat kategorizáljuk, tehát az „Európa” tartami fokategórián belül olyan tartalmi alkategóriákat állítsunk fel, melyekbe az indukált hívószavak besorolhatóak. A tartalmi alkategóriák konstruálása során tudatosan eltekintettünk attól, hogy a felállításra kerülő alkategóriákhoz körülbelül azonos számú hívószó tartozzon, mert úgy véltük, hogy az egyes alkategóriákat reprezentálni képes hívószavak mennyisége is kifejez(het)i majd a hangsúlyokat. A hívószavak alapos és többszintú áttekintését követően az alábbi öt tartalmi alkategória született:

- Európa mint az államok/nemzetállamok konstrukciója

- Európa mint (belső és külső) eröviszony-alakitó és/vagy -fenntartó konstrukció

- Európa mint egységes egész konstrukció

- Európa mint ipari/kereskedelmi konstrukció

- Európa mint müveltségi/müvelődési konstrukció

A 104 db hívószó pedig az alábbi megoszlásban képviseli az egyes tartalmi alkategóriákat:

- Európa mint az államok/nemzetállamok konstrukciója: 30 db hívószó ${ }^{10}$

- Európa mint (belső és külső) erőviszony-alakító/-fenntartó konstrukció: $49 \mathrm{db}$ hívószó ${ }^{11}$

- Európa mint egységes egész konstrukció: 8 db hívószó ${ }^{12}$

\footnotetext{
10 abszolút monarchiák, abszolutizmus, alattvalók, alkotmányos fejlődés, alkotmányos uralom, alkotmányosság, államok, birodalom, birtokok, dinasztia állása, Európán kívüli alkotmány, fejedelmek, kormányok, köztársaság, (nagy)hatalmak, nemzetek/népek, Oroszország, országok, parlamentáris alkotmány, tengeri hatalmak, török birodalom, török tartományok, Törökország, udvarok, uralkodók, város, vezető államférfi/miniszter, vezető államok/országok, vezető hatalom, vezető szerep/parancsoló állás

11 beavatkozás, béke, (béke)konferencia, (béke)kongresszus, békés fejlődés, diplomácia, ellenszenv/támogatás hiánya, érdeklődés/figyelem, események, (fegyveres) harc/konfliktus, felkelések, forradalmak, forradalmi eszmék, forradalmi szellem, gyámság, gyarmatállamok, gyarmatbirodalom, gyarmatok, gyarmatosítás, gyarmatosító államok, (háborús/fegyveres) szembenállás, hadi célok/hadi fejlesztés, hadsereg, (hatalmi) befolyás, hatalmi/politikai egyensúly, hegemónia, helyzet(kép), hódítás, jóváhagyás/helybenhagyás, keleti kérdés, kivándorlási mozgalmak, követelések, külkapcsolat, külügyi politika, küzdelmek, legitimáció, mozgalmak, politika, reakció, régi Európa, rokonszenv/támogatás, szabadság mozgalmak, szabadságharc, szociális mozgalmak, szövetségi rendszerek, tekintély fenntartása, terjeszkedés, tisztek, vér nélküli diadal, viszonyok

12 általános áramlat, egész/egység, kontinens, közszellem, minta/mód, terjedelem/méret, (újkori) modern, (újkori) történelmi áttekintés
} 
- Európa mint ipari/kereskedelmi konstrukció: 9 db hívószó ${ }^{13}$

- Európa mint müveltségi/müvelődési konstrukció: 8 db hívószó ${ }^{14}$

\section{A HÍvÓsZAVAKRA ÉPÍtVE A TARTALMi ALKATEGÓRIÁK VIZSGÁLATA}

A megalkotott öt tartalmi alkategória közül tehát az „Európa mint az államok/nemzetállamok konstrukciója” és az „Európa mint (belső és külső) erőviszonyalakitó/-fenntartó konstrukció" rendelkezik a legnagyobb hívószó bázissal (30, illetve $49 \mathrm{db}$ hívószó). A további három alkategória pedig körülbelül azonos számú $(8,9$, illetve 8 db), az előző kettő alkategóriához képest mintegy negyedét, ötödét kitevő hívószókészlettel bír.

Az alkategória-rendszer felállításának, valamint a hívószavak alkategóriákhoz társításának véglegesítését követően először tankönyvenként, a tartalmi alkategóriák mentén csoportosítottuk a konkrét tankönyvi idézetekhez társított hívószavakat. A hívószavak tankönyvi rendszerezését táblázatok, illetve diagramok segítségével végeztük el, mely lehetőséget teremtett a hívószavak mennyiségi faktorainak többszintú - az „Európa” főkategória és a tartalmi alkategóriák szintjén horizontálisan és vertikálisan egyaránt szisztematizált rögzítésére is.

Ahogy fentebb már utaltunk rá, a 15 db történelemtankönyv vizsgált fejezeteiben/alfejezeteiben összesen $468 \mathrm{db}$ „Európa” főkategória előfordulást („Európá”-t reprezentáló) szóösszetételt, kifejezést, előtagot és rövidítést) azonosítottunk, melyek mindegyikéhez tehát egy-egy hívószót társítottunk. Ezt követően a hívószavak előfordulását a tartalmi alkategóriák mentén, tankönyvenként összesítettük. Ennek során pedig többféle csoportosítási aspektust (kiadás éve, szerzői ábécérend és hívószavak száma szerinti csoportosítás) is figyelembe vettünk, mely néhány kutatói „alapkonzekvencia” érzékeltetésének teret engedett.

Valamennyi tankönyvben egyértelmúen láthatóvá vált az „Európa mint az államok/nemzetállamok konstrukciója” és az „Európa mint (belső és külső) eröviszonyalakitó/-fenntartó konstrukció" tartalmi alkategóriák túlsúlya. Az előbbi - tankönyvtől függően - 29,5 \%-tól 58 \%-ig (a leányközépiskolai tankönyvben: 62,5 \%-ban), míg az utóbbi hasonlóképpen 29 \%-tól 50 \%-ig (a leányközépiskolai tankönyvben: 0 \%-ban) jellemzi a vizsgálati mintát. E két tartalmi alkategória tankönyvi előfordulása tehát körülbelül azonos arányú, amit az is bizonyít, hogy hat tankönyv esetében az egyik (lásd Mangold, 1885; Mika, 1904, 1912; Szigethy, 1903; Ujházy, 1904; Takáts, 1917), míg további hat tankönyv esetében (lásd Mangold, 1891, 1902; Márki, 1903; Sebestyén, 1906; Ujházy, 1913; Varga, 1904) a másik alkategória van jelen nagyobb arányban. Három tankönyvi egységben pedig a két alkategória százalékos megjelenése azonos (lásd Szölgyémy, 1914;

\footnotetext{
${ }^{13}$ hitelezők, iparcikkek, ipari védekezés, iparos állam, iparos országok, kereskedelem, közlekedés, szállított nyerstermékek, távolsági összeköttetés

14 egyetemek, hagyományok, jogfelfogás, kereszténység, múveltség, oktatók, tanulmányút, társaságok
} 
Vaszary, 1904, 1912). A további három tartalmi alkategóriát tekintve ennél jóval kevesebb százalékos előfordulás jellemző. Az „Európa mint egységes egész konstrukció" 0-20,5 \% között, az „Európa mint ipari/kereskedelmi konstrukció" 0-7,1 \% között, míg az „Európa mint müveltségi/müvelodési konstrukció” 0-8,5% között van jelen a tankönyvekben.

A kiadás éve (időrend) szerinti csoportositás alapján megállapítható, hogy az 1891 és 1903 közötti években megjelent tankönyvekben (Mangold, 1891, 1902; Szigethy, 1903; Márki, 1903) a leggyakoribb az „Európa” főkategória előfordulása, tehát e kötetekben a legtöbb az „Európa” főkategória tartalmi alkategóriái hívószavainak összszáma (44-51 db között) (lásd 1. ábra).

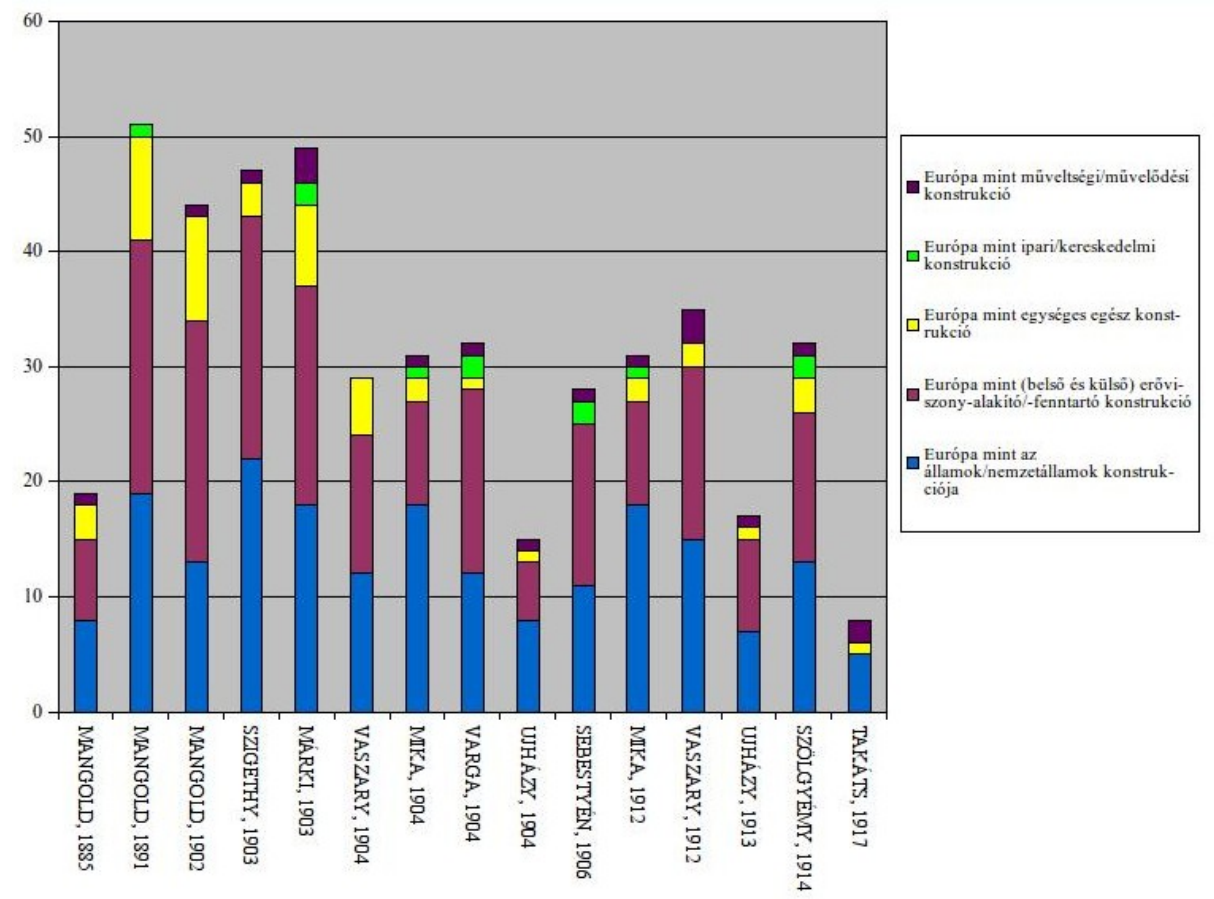

1. ábra. A tartalmi alkategóriák megoszlása tankönyvenként magyar kiadás éve szerinti csoportosításban) (db)

Ha az egyes alkategóriák reprezentációját közelebbről is megvizsgáljuk, akkor egyrészt - ahogy fentebb utaltunk rá - az „Európa mint a(z) (nemzet)államok konstrukciója” és az "Európa mint (belso és külső) erőviszony-alakitó és/vagy-fenntartó konstrukció" tartalmi alkategóriák dominanciája nyilvánvaló. Másrészt pedig szintén az 1891-1903 közötti években az „Európa mint egységes egész konstrukció" alkategória hívószavainak a száma érzékelhetően (de nem kiemelkedően) magasabb mint az azt követő dualizmus kori években. 
További csoportosítási lehetőséget jelent a tartalmi alkategóriák megoszlására vonatkozó adatok szerzői ábécérend (azon belül pedig a kiadási évek) alapján történő kategorizálása.

A tartalomelemzés során 10 szerző összesen 15 db tankönyvére fókuszálunk. E kötetekből 4 szerző munkája emelhető ki, amelyek több kiadását is megvizsgáltuk: Mangold, 1885, 1891, 1902; Mika, 1904, 1912; Ujházy, 1904, 1913; Vaszary, 1904, 1912).

E tankönyveket áttekintve a kiadások előrehaladtával az „Európa” reprezentáció gyakorisága többnyire fokozódik, mindazonáltal a kötetektől (szerzőktől) függően ennek mértéke eltérő (lásd 2. ábra).

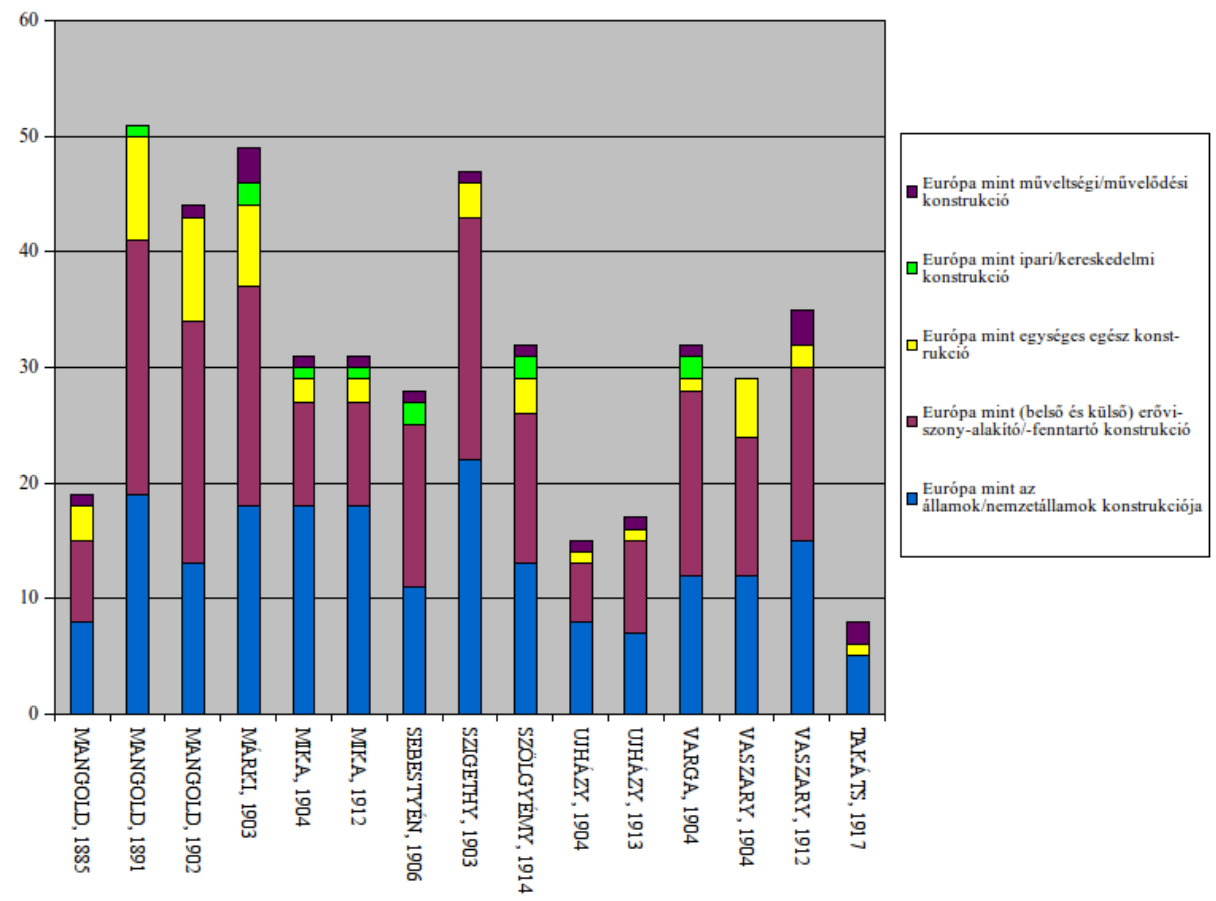

2. ábra. A tartalmi alkategóriák megoszlása tankönyvenként) (db)

A harmadik csoportosítási törekvés a hívószavak mennyisége szerint rendezi növekvő sorrendbe a tankönyvekből nyert adatokat. A 3. ábra alapján látható, hogy a kiadás éve (időrend) és a hívószavak mennyisége között nem áll fent releváns összefüggés. Mindazonáltal a diagram arra is rávilágít, hogy valamennyi vizsgált tankönyvi egységben az egyes tartalmi alkategóriák egymáshoz viszonyított aránya - figyelembe véve a változó hívószó bázis mennyiségét - körülbelül azonos (lásd az 1815 utáni tankönyvi fejezetek, alfejezetek tartalomelemzésének 6. lépése: A hívószavakra építve a tartalmi alkategóriák vizsgálata, 4 . bekezdés). 


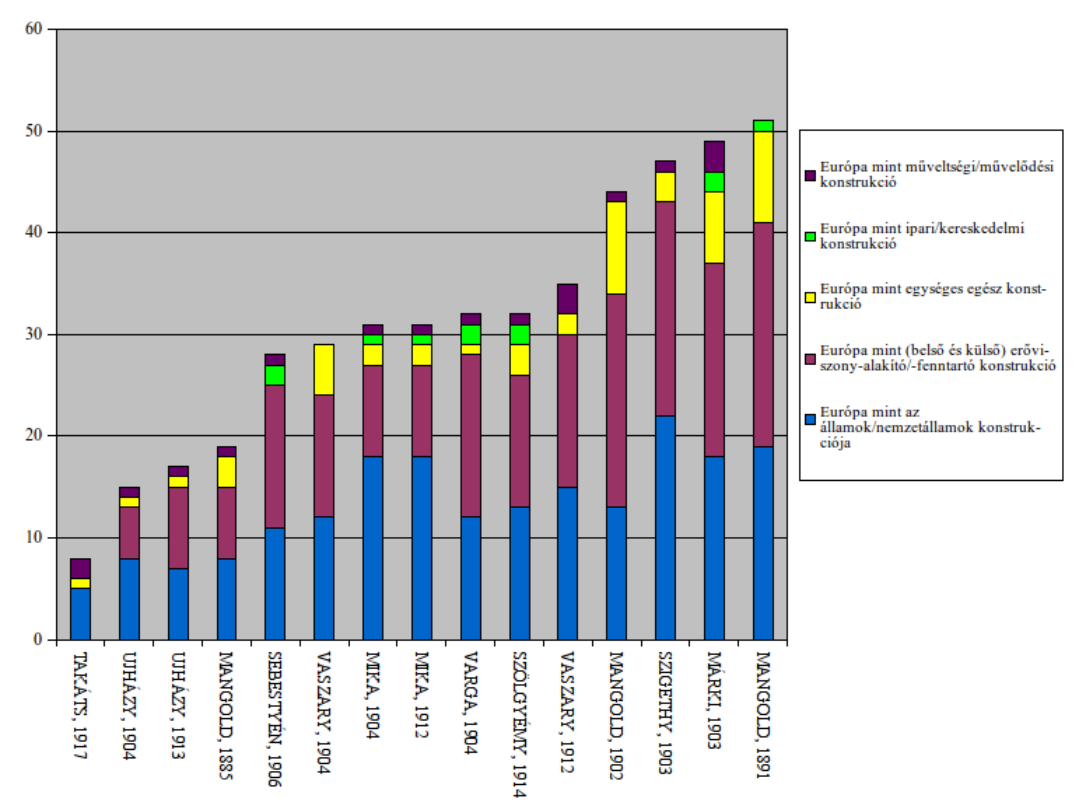

3. ábra. A tartalmi alkategóriák megoszlása tankönyvenként (hívószavak száma szerinti csoportositásban) (db)

A tankönyvenkénti bontás mellett a hívószavak számát a tartalmi alkategóriák mentén, a teljes vizsgálati minta szintjén is szükséges összesíteni. A 468 db hívószó 42,5 \%-a (199 db hívószó) az „Európa mint az államok/nemzetállamok konstrukciója”, 40,8%-a (191 db hívószó) pedig az „Európa mint (belsó és külső) erőviszony-alakító/-fenntartó konstrukció" alkategóriát képviseli. E két (nagy) alkategória tehát a 468 db hívószó 83,3 \%-át reprezentálja. Az „Európa mint egységes egész konstrukció” 10,5 \%-ot (49 db), az „Európa mint müveltségi/müvelődési konstrukció" 3,8%-ot (18db hívószó), míg az „Európa mint ipari/kereskedelmi konstrukció" alkategória 2,4 \%-ot (11 db) tesz ki.

Emellett érdemes egy pillantást vetni az egyes alkategóriák leggyakoribb, illetve legnagyobb számban előforduló hívószavaira is. Az "Európa mint az államok/nemzetállamok konstrukciója" tartalmi alkategória rendelkezik a legnagyobb számban előforduló hívószavakkal. Ezek közt találjuk a "(nagy)hatalmak” (48 db), az "államok" (31 db) és a "nemzetek/népek" (24 db) hívószavakat.

Tankönyvi példák (idézetek) a „(nagy)hatalmak”, az „államok” és a "nemzetek/népek" hívószavakhoz:

(nagy)hatalmak:

„De bámulatosan fejlődött az új német császárság is, mely teljesen nemzeti alapon alakúlt meg s néhány év alatt Európa vezető hatalmassága lett." (Márki, 1903. 163-164. о.). 
„Orosz-török háború 1828-29. E pillanatban a görög forradalmat a bukástól az európai hatalmak közbelépése mentette meg. [...] Midőn Mohamed szultán az európai hatalmak közbelépését visszautasította, az egyesült angol, francia és orosz hajóhadak a török hajóhadat a Navarinnál vívott ütközetben megsemmisítették (1827)." (Mika, 1904. 130-131. o.).

államok:

„Az 1870-71. évi német háború a francziák ellen. [... ] Mialatt a legtöbb európai állam a francziák diadalát biztosra vette, kik maguk is az egész hadjáratot Berlin-be teendő sétának nevezték, egyszerre csak a harcztérről ellenkező hírek érkeztek, melyekből kitûnt, hogy a három német hadtest megtámadta a késedelmező francziákat és egyrészt Saarbrücken, másrészt Weiszenburg és Wörth-nél visszaszorította azokat, mely utóbbi két csatában a porosz trónörökös vezérlete alatt küzdő bajorok verték vissza Mac Mahon csapatjait. (1870. augusztus 2-6.)" (Mangold, 1891. 262. o.).

„1867-ben Ausztria is alkotmányt kapott. Igy tehát a hetvenes évek körül a legtöbb európai államban diadalra jutott a liberalismus." (Vaszary, 1912. 152. o.). nemzetek/népek:

„A februári forradalom hatása Olasz- és Németországban. Első kisérletek a nemzeti egyesúlésre. - A júliusi forradalom nagy reményeket ébresztett az európai népekben, de Belgium kivételével mindenütt a reakció felülkerekedése járt a nyomukban. Oroszország kegyetlen csapással mindenkorra véget vetett a lengyel szabadságnak, s ameddig Ausztria hatalma ért az olasz félszigeten és a német birodalomban, Metternich útját állta a népek törekvéseinek." (Sebestyén, 1906. 195. o.).

„Nemzeti államok alakulása. A krimiai háború. Az ötvenes évek reakciója visszazökkentette az európai népek közéletét a forradalom előtt fönnállott viszonyok közé. A belső mozgalmak egyelőre elültek s a közfigyelem a külső politika felé fordult, melyben a krimiai háború foglalkoztatta a hatalmakat." (Ujházy, 1913. 156. o.)

Szintén kiemelkedik a sorból az „Európa mint egységes egész konstrukció” tartalmi alka-tegória „egész/egység” (31 db), valamint az „Európa mint (belső és külső) erőviszony-alakító/-fenntartó konstrukció" ",béke” (19db) hívószava.

Tankönyvi példák (idézetek) az „egész/egység” és a „béke” hívószavakhoz: egész/egység:

„Ekkép történt, hogy az elmaradt Oroszországot és Törökországot leszámítva, manapság egész Európában alkotmányos élet van és így a szabadelvú eszmék annyi küzdelem után is végre diadalt arattak." (Varga, 1904. 163. o.).

„A kormányok szervezkedése a régi alapon. Franciaországban. A szent szövetség értelmében Európa minden részében a legitimitás elvén kivúl az abszolut hatalmat is visszaállították és a forradalmi elemet üldözőbe vették." (Vaszary, 1904. 137. o.).

béke:

„Lajos Fülöp. 1830-1848. [... ] Lajos Fülöpnek az volt a legnagyobb gondja, hogy Európát békés szándékai felől megnyugtassa, bizalmatlanságát eloszlassa 
és elismertetését kivívja. Ennek fejében megtagadta a lengyelek segítését és megengedte, hogy Ausztria az itáliai forradalmakat elnyomhassa." (Ujházy, 1913. 143. o.).

„(A hármas szövetség.) Oroszország a berlini congressus határozatai miatt megneheztelt Németországra, s úgy látszott, hogy Franciaországgal szövetségre lép. Minthogy e két hatalomnak közeledése háborút idézhetett volna fel Németország ellenében, Németország szövetségre lépett Ausztria' és Magyarországgal (1879), mely hatalom szintén veszélyeztetve volt Oroszország részéről BoszniaHercegovina megszállása miatt. E szövetséghez később (1883) Olaszország is csatlakozott s ennek oka az volt, Olaszország ellensúlyozni akarta Franciaországot, mely ez időben szállotta meg az olaszoktól sûrûn lakott Tuniszt. Az így létesült hármas szövetség azóta éber szemmel ôrködik Európa békéjén." (Vaszary, 1912. 154. о.).

$\mathrm{Az}$ „Európa mint müveltségi/müvelödési konstrukció” alkategória önmagában nem bír magas számú hívószó bázissal (összesen 18 db hívószóval), ugyanakkor - az alkategórián belüli magas aránya miatt - kiemelkedik a többi közül a „müveltség" elnevezésú hívószava (8 db).

Tankönyvi példák (idézetek) a "müveltség” hívószóhoz:

müveltség:

„Angolország reformkorszaka. [...] Óriási gyarmatai voltak a föld minden részében s iparának fejlettségéhez foghatót a világtörténelem nem mutathatott fel. Anglia volt a múvelt Európa eszményképe, a hova minden államférfiú és közgazda tanúlni ment; pl. Széchenyi István gróf 27-szer járt ottan s nemzetét szóval és tettel buzdította az angol szorgalom követésére." (Márki, 1903. 144. o.).

„Magyarország átalakulása. Széchenyi István gróf. [...] Az átalakulás szorosan össze van forrva Széchenyi István gróf nevével, aki Magyarország hátramaradottságának $\mathrm{s}$ a nemzet életképességének fölismerése után a maga nagy ambiciójához és hatalmas tehetségéhez mért föladatnak tekintette, hogy Nyugat-Európa múveltségét és politikai szabadságát hazájába átültesse." (Ujházy, 1913. 136. о.).

$\mathrm{Az}$ „Európa mint ipari/kereskedelmi konstrukció” szintén kevés számú hívószóval rendelkezik (11 db), melyek közül azonban - számát és arányát tekintve - nem emelkedik ki egyik hívószó sem.

A teljes vizsgálati minta szintjén arra is igyekeztünk fényt deríteni, hogy a hívószavak közt találhatóak-e olyanok, melyek valamennyi tankönyvben (vagy csaknem mindben) legalább egy alkalommal szerepelnek. E tekintetben a hívószavak közül egyértelmúen az - „Európa mint az államok/nemzetállamok konstrukciója” tartalmi alkategóriához sorolt - „(nagy)hatalmak” hívószó kerül előtérbe, mely minden vizsgált tankönyvi egységben fellelhető. Két további hívószó: az „államok" és a "nemzetek/népek" egy-egy tankönyv kivételével (előbbi esetében: Ujházy, 1904; utóbbi esetében: Takáts, 1917) szintén megtalálható az elemzett kötetekben. E három hívószón felül két további hívószó, illetve egy ún. hívószócsoport megemlítése is szükséges, melyek nem reprezentálják ugyan a teljes mintát, de a vizsgált múvek $\frac{2}{3}$-ában (10 db tankönyvben) jelen vannak. E két 
hívószó a „béke", valamint az „egész/egység”. A hívószó-csoportot pedig a „vezeto pozíció" kérdésköre jelenti, mely a következő hívószavakat foglalja magában: "vezeto államférfi/miniszter", „vezetó államok/országok”, „vezetö hatalom”, ,vezeto szerep/parancsoló állás".

\section{ÖSSZEGZÉS - A VIZSGÁlATI EREDMÉNYEK RÖGZÍTÉSE AZ „EURÓPA” MINT TARTALMI FŐKATEGÓRIÁRA VONATKOZÓAN}

Az „Európa-kép” tartalmi elemzése során a vizsgálati minta 1815 utáni fejezeteit, alfejezeteit vettük górcső alá, hogy lássuk, miként ábrázolták Európát, az európaiságot a dualizmus kori középiskolai történelemtankönyvek. A tartalmi főkategóriák (azon belül pedig kiemelten „Európa”), a tartalmi alkategóriák és a hívószavak hármas rendszere a tankönyvi „Európa-kép” többszintú, egymásra épülő, árnyalt elemzését tette lehetővé, mely kvantitatív és kvalitatív kutatási eredmények kibontakozásának egyaránt teret engedett.

A kutatás kvantitatív szempontból igazolta Európa történelmének tankönyvi dominanciáját, kvalitatív szempontból pedig közelebb kerültünk a dualizmus kori középiskolai történelemtankönyvek „Európa-kép”-ének konceptualizálásához, a tartalmi hangsúlyok azonosításához.

\section{A KUTATÁSI EREDMÉNYEK SZINTETIZÁLÁSA}

A vizsgált tankönyvekből és tankönyvi egységekből kibontakozó „Európa-kép”et több aspektusból is megközelítettük. Ennek során figyelmet fordítottunk egyrészt a tankönyvi arányok, másrészt a fogalmi keretek, harmadrészt pedig a hangsúlyváltozások feltárására.

E kérdéscsoport mentén a tankönyvekből kibontakozó „Európa-kép” az alábbiak szerint összegezhető:

Tankönyvi arányok:

- Egyértelmúen az Európa-centrikus tankönyvi (és tantervi) tartalom a jellemző.

Fogalmi keretek:

- Az Európa/európaiság fogalma definiálatlan; nem jelenik meg deklarált Európa-fogalom.

- A tartalomelemzés révén ugyanakkor a látens „tankönyvi európaiság” meghatározható. A vizsgált dualizmus kori egyetemes középiskolai történelemtankönyvek Európát elsősorban mint (nemzet)államok összességét ábrázolták, illetve eróviszony-alakító és -fenntartó szerepét hangsúlyozták. Európa mint a (nemzet)államok összessége mindenekelőtt a "(nagy)hatalmak”, az „államok”, valamint a „nemzetek/népek” összességeként értelmezhető, másrészt Európa mint erőviszony-alakító és -fenntartó konstrukció két fő pilléren: az „egység”-en és a „béké"”-n nyugszik.

E megállapítások egyúttal az „Európa-kép”-et befolyásoló tankönyvi tartalmak állandó tendenciáinak is tekinthetők. 
Hangsúlyváltozások:

- Az „Európa-kép”-et befolyásoló tankönyvi tartalmak változásait tekintve a vizsgálat során markáns tendenciák nem tárultak fel, mindazonáltal néhány tartalmi jellemvonás körvonalazható.

- A századforduló körüli években az Európa-reprezentáció erősebb, mint a megelőző és következő években.

- Az 1891-1903 közötti években Európa globalitása szintén némileg hangsúlyosabb, mint a dualizmus későbbi tankönyveiben.

- Ugyanazon tankönyvi kötetek különböző kiadásaiban, a kiadások előrehaladtával az „Európa”-reprezentáció gyakorisága többnyire növekedett, mindazonáltal a kötetektől (szerzőktől) függően ennek mértéke eltérő volt.

\section{FELHASZNÁLT IRODALOM}

Adamikné Jászó Anna (szerk.) (1990): A magyar olvasástanítás története. Tankönyvkiadó, Budapest.

Antal László (1976): A tartalomelemzés alapjai. Magvető Kiadó, Budapest.

Babbie, E. R. (2008): A társadalomtudományi kutatás gyakorlata. 6., átdolgozott kiadás, Balassi Kiadó, Budapest.

Dárdai Ágnes (2002): A tankönyvkutatás alapjai. Dialóg Campus Kiadó, Budapest-Pécs.

Dombi Alice (2015): Zsinórmérték és útmutatás. Tankönyvek és tankönyvírók a 19. században Magyarországon. Universitas Szeged Kiadó, Szeged.

Domokos Zsuzsa (2002): Az európaiság fogalma történelem tanterveink, tankönyveink tükrében. In: Szabolcs Ottó (sorozatszerk.): Történelempedagógiai Füzetek 12. A Magyar Történelmi Társulat Tanári Tagozata és az ELTE BTK kiadványa, Budapest. 5-23.

Európa-kutatás. In: Szabolcs Ottó és Katona András (2006, összeáll.): Történelem tantárgy-pedagógiai olvasókönyv. Dokumentumok a történelemtanítás történetének és módszertanának tanulmányozásához. Nemzeti Tankönyvkiadó, Budapest. 571-581.

Farkas Mária (2008): Történelemtanítás a népiskolákban a dualizmus kori Magyarországon. Szemléletformálás és értékközvetítés tantervek, olvasó- és történelemkönyvek tükrében. Trezor Kiadó, Budapest.

Fischerné Dárdai Ágnes (2011): A tankönyvek európai dimenziója. In: Borsodi Csaba (sorozatszerk.): A keresztény Európától az Európai Unió magyar elnökségéig. A Történelemtanári Továbbképzés Kiskönyvtára LV. Magyar Történelmi Társulat Tanári Tagozata - Eötvös Loránd Tudományegyetem Bölcsészettudományi Kar, Budapest. 50-68.

Fischerné Dárdai Ágnes (2012): Mit jelent az európai dimenzió a tankönyvekben? In: Orsós Anna és Trendl Fanni (szerk.): Útjelzők. Ünnepi kötet pályatársak, kollégák, tanítványok neveléstudományi tanulmányaiból a 70 esztendős Forray R. Katalin tiszteletére. PTE BTK, Pécs. 92-99. 
Gróz Andrea (2005): Az eredményes pedagógus egy 19. századi tanítóképzés pedagógiai tankönyv tükrében. Neveléstörténet, 2. 3-4. sz. 199-204.

Gróz Andrea (2007): A pedagógus-gyermek kapcsolat alakulása a dualizmus korában, tanítóképzős pedagógiai szakkönyvek tükrében. Doktori (PhD) disszertáció. Eötvös Loránd Tudományegyetem Neveléstudományi Doktori Iskola, Budapest.

Horváth Szilvia (2009): Az európai identitás diskurzuselméleti kérdései. Politikatudományi Szemle, XVIII. 4. sz. 105-125.

Letöltés: http://www.poltudszemle.hu/szamok/2009_4szam/horvathsz2009-4.pdf 2015. július 9. 13:45

M. Császár Zsuzsa (2004): Európa-kép a magyar földrajzoktatásban. In: III. Magyar Politikai Földrajzi Konferencia. Az integrálódó Európa politikai földrajza. PTE TTK Földrajzi Intézet, Pécs. 80-83.

Méreg Martin (2015): Schultz Imre népiskolai reálolvasókönyvének didaktikai felépítése német nyelvú olvasókönyvek tükrében. In: Andl Helga és Molnár-Kovács Zsófia (szerk.): Iskola a társadalmi térben és időben V. PTE „Oktatás és Társadalom" Neveléstudományi Doktori Iskola, Pécs. 83-103.

Mészáros István (1991): Európaiság, magyarság régi tankönyveinkben. Új Pedagógiai Szemle, XLI. 4. sz. 10-14.

Mollat du Jourdin, M. (1996): Európa és a tenger. Európa születése. Atlantisz Könyvkiadó, Budapest.

Molnár-Kovács Zsófia (2014): Az „Európa-kép“-kutatás fókuszpontjai a magyar és nemzetközi tankönyvi szakirodalom tükrében. Történelemtanítás Online történelemdidaktikai folyóirat, (XLIX.) Új folyam V. 2-4. sz.

Letöltés: http:/ / www.folyoirat.tortenelemtanitas.hu/wp-content/uploads /2014/12/05_02_12_Molnar.pdf 2015. június 25. 12:26

Molnár-Kovács Zsófia (2016): A dualizmus kori magyar középiskolai egyetemes történelemtankönyvek és azok változatai. Történelemtanitás - Online történelemdidaktikai folyóirat, (LI.) Új folyam VII. 3-4. sz.

Letöltés: http:/ / www.folyoirat.tortenelemtanitas.hu/wp-content/uploads/ 2016/12/07_03_06_Molnar-Kovacs.pdf 2016. december 22. 10:20

Nóbik Attila (2010): Klasszikusok és kánonképzés a magyar neveléstörténeti tankönyvekben (1867-1956). Doktori (PhD) értekezés. Szegedi Tudományegyetem Neveléstudományi Doktori Iskola, Szeged.

Penke Olga (2000): Filozofikus világtörténetek és történetfilozófiák. Balassi Kiadó, Budapest.

Seewann, G. (2009): A Németországról alkotott kép Magyarországon a 20. század első felében. In: Hornyák Árpád és Vitári Zsolt (szerk.): A magyarságkép a közép-európai tankönyvekben a 20. században. Kutatási füzetek 14. Pécsi Tudományegyetem, Pécs. 99-110.

Szabolcs Éva (2004): Tartalomelemzés. In: Falus Iván (szerk.): Bevezetés a pedagógiai kutatás módszereibe. Múszaki Könyvkiadó, Budapest. 330-339. 


\section{TANKÖNYVEK}

Mangold Lajos (1885): Világtörténelem. Középtanodai használatra. Harmadik kötet. Újkor és legujabb kor. Második, az új tanterv alapján ujonnan kidolgozott kiadás, képekkel és térképekkel, Franklin-Társulat, Budapest.

Mangold Lajos (1891): Világtörténelem. Középiskolai használatra. Harmadik kötet: Újkor és legujabb kor. Harmadik kiadás, Franklin-Társulat, Budapest.

Mangold Lajos (1902): Világtörténelem. Középiskolai használatra. Harmadik kötet. Ujkor 1648 óta s a legujabb kor. Ötödik, az uj tanterv alapján átdolgozott kiadás, Franklin-Társulat, Budapest.

Márki Sándor (1903): Egyetemes történelem. Gymnasiumok és reáliskolák számára. III. rész. Az új-kor 1648-1871-ig. A VII. osztály részére. Singer és Wolfner, Budapest.

Mika Sándor (1904): Világtörténet. Az uj tanterv alapján a középiskolák felső osztályai számára. III. kötet. - Uj-kor és legujabb kor. Lampel Róbert (Wodianer F. és Fiai) cs. és kir. udv. könyvkereskedés kiadása, Budapest.

Mika Sándor (1912): Világtörténet. Az új tanterv alapján a középiskolák felső osztályai számára. III. kötet. Új-kor és legújabb kor. Második kiadás, Lampel R. Kk. (Wodianer F. és Fiai) R. T. Könyvkiadóvállalata, Budapest.

Sebestyén Gyula (1906): Egyetemes történet. A középiskolák felsőbb osztályai számára. III. kötet. Újkor (1648-1871). Franklin-Társulat, Budapest.

Szigethy Lajos (1903): Egyetemes történet. Az 1899-ik évi tanitási terv szerint középiskolák VII. osztálya számára. Harmadik rész. Új-kor (1648-tól). Singer és Wolfner, Budapest.

Szölgyémy János (1914): Világtörténet. Főtekintettel a magyar nemzet történetére 1648-1913-ig. Európa és Amerika nevezetesebb államainak földrajzával. III. rész. Az új tanterv értelmében átdolgozott harmadik kiadás, Lampel R. Kk. (Wodianer F. és Fiai) R. T. Könyvkiadóvállalata, Budapest.

Takáts György (1917): Történelem. Leányközépiskolák használatára. Az új tanítástervnek megfelelöen leányközépiskolák (felső leányiskolák, leánygimnáziumok és felső kereskedelmi leányiskolák) III. osztálya számára. A középkor és újkor történetének vázlata a magyarok honfoglalásától napjainkig. Negyedik, lényegesen átdolgozott kiadás, Athenaeum Irodalmi és Nyomdai Részvénytársulat kiadása, Budapest.

Ujházy László (1904): Egyetemes történelem. Középiskolák felső osztályai számára. III. rész. A hetedik osztály részére. Szent-István-Társulat kiadása, Budapest.

Ujházy László (1913): Egyetemes történelem. Középiskolák felső osztályai számára. III. rész. A hetedik osztály részére. Második átdolgozott kiadás, Szent-IstvánTársulat kiadása, Budapest.

Varga Ottó (1904): Világtörténet. Tanterv és utasitások alapján a középiskolák számára. Harmadik kötet: Új-kor. Harmadik javitott kiadás, Franklin-Társulat, Budapest.

Vaszary Kolos (1904): Világtörténelem. Középiskolák számára. III. kötet. A legújabb miniszteri tantervhez alkalmazott hatodik kiadás, Lampel Róbert (Wodianer F. és Fiai) cs. és kir. udvari könyvkereskedés kiadása, Budapest. 
Pedagógiatörténeti Szemle • 2. évf. 1-2. sz. 40-60. o. • 2016

DOI:10.22309/PTSZEMLE.2016.1.3

Vaszary Kolos (1912): Világtörténelem. Középiskolák számára. III. kötet. Újkor (1648-1789.) és legújabb kor (1789-től napjainkig). (Átdolgozta és kiegészítette: Németh Ambrus). Hetedik kiadás, Lampel R. Kk. (Wodianer F. és Fiai) R. T. Könyvkiadóvállalata, Budapest. 


\title{
A kereskedelmi iskoláink a 19. századi német és francia szakoktatás tükkrében
}

\author{
NAgy AdrienN \\ Magyar Nemzeti Levéltár Országos Levéltára
}

\begin{abstract}
A 19. század második felében kibontakozó hazai középfokú kereskedelmi szakképzés mintájául a német, osztrák, valamint a francia kereskedelmi szakoktatási „modell” szolgált. A rendelkezésünkre álló elsődleges (szervezeti szabályzatok, iskolai értesítők, tantervek) és másodlagos források vizsgálata, összehasonlító elemzése során arra kerestük a választ, hogy vajon az Eötvös József és munkatársai által feltérképezett, így különös figyelmet kapó német, osztrák és francia szakiskolai rendszer egyes elemei (a képzés szerkezetét, a tananyag tartalmát és a végzettséget tekintve) megjelentek-e, ha igen, milyen formában a hazai kereskedelmi iskolák megszervezése során. Továbbá vizsgálatunk tárgyát képezte annak feltérképezése, hogy miként alakult e hangsúlyosan gyakorlati képzést is nyújtó, közvetlenül a munkaerőpiacra felkészítő közép/felső kereskedelmi iskolatípusban az elméleti és a szakmai tantárgyak óraszámának aránya.
\end{abstract}

\section{A NÉMET, OSZTRÁK ÉS A FRANCIA KÖZÉPFOKÚ KERESKEDELMI SZAKKÉPZÉS MEGSZERVEZÉSE}

A német fejedelemségek területén a 18. század végén és a 19. század elején múködött néhány kereskedelmi tárgyakat is tanító iskola, de ezek jelentős része a napóleoni háborúk idején megszúnt, így a német kereskedelmi szakoktatás fejlődése csak az 1830-as években vett újabb lendületet. Magdeburg város tanácsa által 1819-ben alapított öt évfolyamos felső ipari és kereskedelmi iskolában (Höhere Gewerbe- und Handelungsschule) a kereskedelmi képzésre az utolsó évben került sor, azonban 1844-ben - miután az intézmény reáliskolává alakult - ez a szakirányú képzés megszúnt (Vincze, 1935. 102. o.). A két évfolyamos danzigi Handelsakademie 1832-ben nyílt meg, azonban ez az iskola a "felsőbb" polgári és a reáliskolát végzett (17-18 éves) növendékeket fogadta. Az intézményben az 1860-as évek elején két, 1878-ban újabb egy évvel csökkentették a felvételi korhatárt, ám így szép lassan általános múveltséget adó polgári iskolává alakult át, elvesztve szakiskolai jellegét, majd 1893-ban megszúnt. A neves szakíró David August Schiebe 1831-ben alapította az első középfokú kereskedelmi iskolát 
Lipcsében. Az Öffentliche Handelslehranstalt intézmény középfokú iskolája a Handelsrealschule (=kereskedelmi reáliskola) volt első olyan kereskedelmi iskola, amely alsó és középfokú kereskedelmi oktatást biztosított egy intézmény keretein belül (Rätzer, 2001). A korszakban hasonló jellegú kereskedelmi iskola múködött Berlin (1843), Drezda (1845), Ausgburg (1845), Zwickau (1847), Chemnitz (1848), Hildburghausen (1849) és Freiburg (1849) városában. A 19. század közepétől a középfokú kereskedelmi képzést a kereskedelmi reáliskolák (Handelsrealschule) és a felsőbb kereskedelmi iskolák (Höhere Handelsschule) szolgálták. Az 1870-es évek végén az intézmények önállóan vagy valamely reáliskolához vagy reálgimnáziumhoz (Königliche Realschule mit Handelsabteilung, Realgymnasium nebst Handelsschule) kapcsolva múködtek. Míg az önálló iskolák két, három vagy hat évfolyamosak voltak, addig a kapcsolatos iskolák csak az utolsó két évben nyújtottak szakképzést (tulajdonképpen a reáliskolai tanulmányaikat egészíthették ki a tanulók egy két éves kereskedelmi tanfolyammal) (Ditchen, 2015). ${ }^{1}$

A nyilvános és a magán, illetve az önálló (19) és a kapcsolt (9 más intézettel kapcsolatos) 28 középfokú kereskedelmi iskola közül 1885-ben 23 intézmény sikeresen vizsgát tett növendékeit megillette az egyéves katonai önkéntességi jog (Ábrai, 1887). A különböző előtanulmányokkal érkező diákoknak szinte minden iskolában felvételi vizsgát (német, francia, földrajz és történelem tantárgyból) kellett tenni. A három évfolyamos képzést a tanulók a magyarhoz hasonló érettségivel zárhatták, mely - akárcsak hazánkban - egyéves önkéntességet biztosított.

Németországban a kereskedelmi iskolák nem a kereskedelmi vagy a közoktatásügyi, hanem a belügyminisztérium alá tartoztak, azonban ez szinte csak névleges volt, mert a minisztérium az iskolák külső, belső szervezetébe nem szólt bele. Továbbá az állam anyagilag sem támogatta jelentős mértékben az iskolákat, jelzi ezt az 1888-ban megítélt, mindössze évi 10.000 márka szubvenció is (Ditchen, 2015). A leghíresebb, 1831-ben alapított lipcsei iskola kapta a legtöbb állami támogatást (4500 márka/év), de ez az összeg is elenyésző volt (6\%) az évi 80.000 márkás költségvetéséhez képest, melynek a tandíjak (évi 360 márka/fő) által nem fedezett részét a helyi kereskedelmi kamara állta (egyúttal biztosítva az épületet is) (Ábrai, 1887; Ditchen, 2015). Az állami „támogatás” tulajdonképpen kimerült az iskolákat sikeresen elvégző, bizonyítványt nyert tanulók számára biztosított egyéves katonai önkéntesség jog megadásában. Az iskolák maguk ezt a kedvezményt úgy ítélték meg, hogy az állam nem a kereskedelmi iskolák érdekében, hanem a hadsereg tiszti aspiránsainak szaporítása céljából adta, amely ugyan a tanulói létszám növekedését vonta maga után, ám egyúttal a kereskedelemi pálya iránt nem érdeklődő, ott elhelyezkedni nem kívánó diákokat kényszerített az iskolákra, megnehezítve ezzel a magas színvonalú szakmai

\footnotetext{
${ }^{1}$ Reáliskolával kapcsolatos Königliche Realschule mit Handelsabteilung: Kaiserslautern, Fürth, Landshut, míg Zittau-ban és Frankfurtban a reálgimnáziummal kapcsolatos kereskedelmi tanfolyam múködött.
} 
képzés fenntartását. Németországban többségében a magánvállalkozások, kereskedők, kereskedelmi testületek karolták fel a kereskedelemi szakoktatás ügyét, sorra alapítva az iskolákat.

Az 1895-ös esztendő csakúgy, mint hazánkban, a német szakiskolai képzésben is a változások éve volt, ugyanis ekkor jött létre a Der Deutsche Verband für das kaufmännische Unterrichtswesen. E szövetség három bizottságában (Handelshochschulen: kereskedelmi főiskolák, Handelsschulen: kereskedelmi iskolák és Fortbildungsschulen: tanonciskolák bizottsága) minden (37) szövetségi állam (280 iskola 46 küldöttje) képviseltette magát, melyek célul túzték ki a kereskedelmi szakképzés átalakítását és a felsőfokú kereskedelmi oktatás megszervezését (Zander, 2004. 58. o., Cocks és Jarausch, 1990).

Németországban 1900-ban 14, a középiskola hatodik osztályára épülő, a szakmai tárgyakra kiemelt hangsúlyt helyező felső kereskedelmi, valamint 36, a szakmai képzés mellett kellő általános múveltséget is nyújtó kereskedelmi reáliskola múködött (Horlebein, 1991. 407. o.). A szövetség (Verband) 1909-ben elfogadott egy úgynevezett „,normál-tanítástervet” a kereskedelmi reáliskolák részére, mely a hatosztályos reálkereskedelmi iskolákat tartotta követendő példának. A javasolt tanterv értelmében az alsó három osztályban a reáliskolák tananyagát tanították, amely a felső három osztályban kiegészült volna a kereskedelmi szaktárgyakkal. Ám ezt a szövetség által kidolgozott tantervet ebben a formában sehol nem vezették be (Horlebein, 1991. 108. o.). A kereskedelmi iskolák szövetségének célja az iskolák egységesítése volt, mely 1914 előtt a gyakorlatban nem valósult meg.

Ausztriában valamivel később szerveződtek az első középfokú kereskedelmi iskolák. A 19. század elején a három évfolyamos reáliskolák egy részének tanulmányi idejét két évre csökkentették, és a harmadik évfolyamot kereskedelmi tagozattá alakították át. Az első, középfokúnak mondható kereskedelmi iskola az 1834-ben Franz Mahr által alapított laibachi kétéves kereskedelmi magániskola volt (Schack és Vincze, 1930). Az elkövetkező évtizedekben több hasonló iskola nyílt (Bécs, Brünn, Graz). Ám ezek az iskolák nem elégítették ki a nagyiparos és nagykereskedő családok igényeit, ezért azok külföldön taníttatták fiaikat. A középfokú kereskedelmi képzés csak az 1850-es évek közepén, a kapuit 1856-ban megnyitó prágai akadémia megszervezésével vette kezdetét, melyet 1858-ben az iparosok és kereskedők társulata által alapított Bécsi Kereskedelmi Akadémia (Verein der Wiener Handelsakademie) követett (Engwall és Zamagni, 1998). A prágai a csehországi kereskedőknek, a bécsi pedig a helyi gazdag kereskedők fiainak szánta iskoláját. Hasonló jellegú képzést nyújtott az 1863-ban a kereskedők és iparosok társulata által alapított grazi akadémia is (Akademie für Handel und Industrie), mely azzal a céllal jött létre, hogy a térség iparosainak kereskedelmi, míg a kereskedőknek alapvető ipari ismereteket nyújtson. Az intézmény az elemi iskola növendékeit három év előkészítő osztályokban eltöltött idő után vette fel a szintén hároméves akadémiai tagozatra. A grazi akadémia tanulói egy közös alapozó képzés után a kereskedői, illetve az ipari tagozat közül 
választhattak (Schack és Vincze, 1930).

A bécsi akadémia egy kétéves előkészítő és egy szintén kétéves akadémiai tagozattal múködött. A kétéves előkészítőt azoknak szánták, akik a középiskolának csak az alsó tagozatát végezték el, míg az akadémiai tagozatra a középiskola befejezése után közvetlenül jelentkezhettek a diákok. Az iskola szerkezete 1872ben átalakult - miután vasúti és biztosítási tanfolyamokat indítva az állam is bekapcsolódott a képzésbe -, az előkészítő tanfolyam kiegészült az akadémia első osztályával, így hároméves kereskedelmi középiskolaként múködött tovább. Az akadémiai tagozat második évfolyama egyesült a fentiekben jelzett tanfolyamokkal és kétéves főiskola (Handelshochschule) jött létre, ám ez csak rövid életû́ volt, mivel a gazdasági nehézségek miatt még 1877-ben megszûnt. Így az ekkor már Wiener Handelsakademie néven ismert iskola a prágaihoz hasonló felső kereskedelmi iskolaként múködött (Vincze, 1935; Scheinder, 2001). Az osztrák középfokú oktatásban a 1868-ban bevezetett önkéntességi kedvezmény a szakoktatásra is hatással volt. Mindazon tanulók, akik valamely három évfolyamos nyilvános kereskedelmi középfokú iskolát elvégezték és végbizonyítványt szereztek, megkapták az egyéves önkéntességet. Azonban e jogot a hazai iskolákkal szemben az osztrák felső kereskedelmi iskolák tanulói nem kapták meg automatikusan, hanem minden iskolának külön kellett kérelmeznie azt a Hadügyminisztériumtól. Bár kereskedelmi érettségi vizsga az osztrák iskolákban is volt, de annak letétele nem volt szükséges az önkéntességi kedvezmény elnyeréséhez. Így nem meglepő, hogy igen alacsony volt az érettségit tett tanulók aránya, hiszen e nélkül is megkapták az önkéntességi jogot. ${ }^{2} \mathrm{~A}$ három évfolyamos kereskedelmi iskolába való felvétel feltétele 1872-től a 14 éves életkor betöltése, valamint a polgári iskola vagy a középiskola alsó osztályainak sikeres elvégzése vagy az eredményes felvételi vizsga. Az egyéves önkéntességgel kecsegtető három évfolyamos középfokú szakiskolák - csakúgy, mint Magyarországon - igen hamar, azok körében is népszerúvé váltak, akik korábban nem választották volna ezt az iskolatípust. A két évfolyamos kereskedelmi iskolák - melyek fenntartásához az állam, a tartomány, a kamara és a kereskedő egyletek is hozzájárultak - végbizonyítványa önkéntességre nem jogosított, ezért az 1870-es évektől egyre inkább háttérbe szorultak, és sorra nyíltak a hároméves intézmények (Innsbruck, Krakkó, Brünn, Reichenberg). Számos két évfolyamos iskola úgy próbált fennmaradni, hogy előkészítő, illetve önkéntességi jogot biztosító vizsgára felkészítő tanfolyamot indított (Schack, 1929. 156. o.). Ausztriában az iskolák fenntartási költségeiből a kereskedelmi kamarák, a testületek és a takarékpénztárak mellett, az állam nagyobb arányban vette ki a részét, mint Németországban. Az 1880-as évek közepén 19 osztrák középfokú kereskedelmi iskola múködött (4431 tanulóval) ${ }^{3}$, közülük hét - három évfolyamos intézmény

\footnotetext{
${ }^{2}$ A churdimi három évfolyamos felső kereskedelmi iskolában 1899/1900-as tanévben 68 tanulóból csak egy fő jelentkezett érettségire (Vincze, 1935).

3 1901/02-es tanévben az osztrák kereskedelmi akadémiák képzéseire 3915 tanuló iratkozott be (német tannyelvú 2329, cseh 1300, olasz 166, lengyel 120). Az abituriensek száma 1119 (645 német,
} 
- akadémiai címet viselt (Bécs 1858, városi alapítású Churdim-i cseh akadémia 1882, kereskedők, iparosok által alapított grázi akadémia 1863, helyi kereskedők által alapított linzi akadémia 1882, állami alapítású trieszti akadémia, helyi kereskedők által alapított prágai németnyelvû́ akadémia 1856, illetve a cseh kereskedők társulata által alapított cseh akadémia 1872), míg a többi, döntően két évfolyamos iskolát a korszakban összefoglaló néven kereskedelmi középiskolaként emlegették, ugyanis elnevezésük igen eltérő volt (Handelsschule, Handels Mittelschule, Handels-Institut, Handels Lehranstalt). A középfokú két és három évfolyamos kereskedelmi iskolák múködését 1910-ben szabályozta a Vallás- és Közoktatásügyi Minisztérium. A három évfolyamos iskolák tanulmányi idejét négy évre emelték. ${ }^{4}$

A 18. század végén Franciaországban létrejött ugyan néhány középfokúnak mondható olyan magániskola, amely kereskedelmi ismereteket tanított, ám ezek igen rövid életû́ek voltak és a 19. század elejére kivétel nélkül mind megszûntek. Az első állandó jellegú középfokú kereskedelmi iskola az 1819ban Párizsban a lyoni kereskedő és jogász Vital Roux és további két párizsi kereskedővel (Brodart és Legret) közösen alapított l'École Spéciale de Commerce et d'Industrie (Fridenson és Paqui, 2008). Az iskola az 1830-as években Adolphe Blanqui - neves francia közgazdász - igazgatása alatt vált igazán népszerúvé, miután 1838-tól állami támogatást nyert. 1852-től immáron École Supérieur de Commerce néven múködött a három évfolyamos 16. életévüket betöltött fiúkat fogadó, ekkor már igen jó hírnévnek örvendő iskola, mely 1860-as évekig Franciaország egyetlen középfokú kereskedelmi iskolája volt.

A szakiskolák kiépülésre a Victor Duruy közoktatási miniszter nevével fémjelzett, a középfokú oktatás átalakítását célul kitűző törvény 1865. június 21-i elfogadása után került sor. Egyéb intézkedések mellett e törvény szabályozta az úgynevezett „speciális középfokú oktatást” („enseignement secondaire spécial") azaz az ipari, a mezőgazdasági, és a kereskedelmi képzést (Graves, 1964). Az 1860-as évek második felében létrejött ugyan néhány a kereskedelemi ismereteket oktató iskola, ám ezek színvonala elmaradt a párizsi iskolától. Középfokú két évfolyamos kereskedelmi iskola nyílt 1871-ben Le Havre-ban, 1872-ben Rouenban, Lyonban, Marseille-ben, 1874-ben Bordeaux-ban, majd 1881-ben Párizsban (Prévor, 1964. 171-172. o.). A 19. század második felében a kereskedelmi iskolák népszerûségét növelte egyrészt az 1875-ben elfogadott katonai szolgálat halasztásáról szóló rendelet, másrészt az 1889-ben a középfokú szakiskolákra is kiterjesztett véderőtörvény biztosította egyéves önkéntességi kedvezmény, melyet minden kétéves nyilvános kereskedelmi iskola tanulója

393 cseh, 67 olasz, 14 lengyel) fő volt. A tartományok kereskedelmi iskoláinak száma: Csehország 9 iskola 1908 tanuló, Morvaország 4 iskola 517 tanuló, Tirol 2 iskola 215 tanuló, Galícia 2 iskola 120 tanuló, Alsó-Ausztria 1 iskola 681 tanuló, Stájerország 1 iskola 271 tanuló, Felső Ausztria 1 iskola 131 tanuló, Trieszt 1 iskola 72 tanuló (Koltai, 1903. 250. o.).

${ }^{4}$ Négy iskola Bécsben (Alte Wiener Handeslakademie, Neue Wiener Handelskademie, Handelsakademie der Wiener Kaufmannschaft Handelsakademie für Mädchen), négy pedig vidéken (Linz, Graz, Klagenfurt, Innsbruck) múködött (Vincze, 1935). 
megkaphatott. ${ }^{5}$ Így az 1890-es években az iskolák igyekeztek nyilvánossági jogot nyerni, ami egyúttal a tanulói létszám növekedését eredményezte. Franciaországban 19. század második felében állami kereskedelmi iskola nem múködött, hanem 10 magánintézmény szolgálta a középfokú kereskedelmi szakképzést, míg Magyarországon az ekkor múködő 23 iskolából 6 volt állami és 7 államilag segélyezett. Néhány kivételtől eltekintve szinte minden kereskedelmi iskola a helyi kereskedelmi kamara patronálása mellett, egy Conseil d'administration (kormányzótanács) elnevezésú felügyelő bizottság irányításával múködött. A bizottság a kamara, továbbá a közéletben és a gyakorlat terén ismert és jártas férfiakból állt, akik döntöttek a tananyagról és a tanítás kivételével intézték az iskolai ügyeket. E rendszerből adódott, hogy a középfokú kereskedelmi iskolát sikeresen elvégzett diákok nem a tanári kar, hanem külön a kereskedelmi miniszter által kinevezett „examinateur” előtt tettek záróvizsgát (Szántó, 1895).

A francia kereskedelmi iskoláknak három típusa különíthető el, a felső kereskedelmi iskolák (Écoles superieures de commerce), az elemi és felsőbb kereskedelmi iskolák (Écoles Commerciales), valamint az esti kereskedelmi tanfolyamok (Cours commerciaux gratuit du soir). Az iskolák szervezetét illetően jelentős különbségek voltak, mivel egységes törvényi vagy egyéb szabályozás nem volt. A képzések közös vonása volt az irodai gyakorlat tantárgy, amelyet általában 6-13 órában oktatták és a heti óráknak átlag egyharmada volt, az angol nyelvet minden iskolában, míg a németet csak kevés helyen tanították. A tanulók reggel 7.30h-tól délután 17.45 h-ig ugyan szünetekkel, de egész nap előadásokat hallgattak. Rendszeresek voltak a heti gyárlátogatások és az egyéb kirándulások. Az 1880-as években több iskola a comptoir-rendszert alkalmazta, melynek lényege volt, hogy az egyes osztályok mint üzletek múködtek, egymással különböző üzleti ügyeket folytattak (Bonin, 2006).

A kereskedelmi miniszter 1898-ben újfent módosította a nyilvánossági jog, illetve az állami elismerés feltételeit, mellyel a felső kereskedelmi iskolák rendtartását valamelyest egységesítette. A rendelet előírta a felvételi versenyvizsgát, melyen a 16. életévet betöltött tanulóknak matematikából, természettanból, vegytanból, földrajzból és történelemből kellett számot adni ismereteikről. A két évfolyamos kereskedelmi iskolák igény esetén indíthattak előkészítő osztályt/tanfolyamot. A kereskedelmi iskolákban 1898-tól központilag, a miniszter által jóváhagyott közös tanterv és fegyelmi szabályzat alapján folyt az oktatás. A sikeres osztályvizsgák után a tanulóknak záróvizsgát kellett tenni, melynek kérdéssorát a miniszter hagyta jóvá. A bizottság tagjai minden tárgyból 0-20-ig

\footnotetext{
${ }^{5}$ 1875. december 31-én a képviselőház a katonai törvény 57. cikkelyének halasztási kedvezményét a kereskedelmi kamarák által szubvencionált iskolák növendékeire is kiterjesztették. A fiatalok a 24. életévükig tolhatták ki bevonulásukat, ha emiatt félbe kellett volna szakítani tanulmányaikat. Egyéves önkéntességi kedvezményt csak külön katonai vizsgálat fejében kaphattak. Azonban a kereskedelmi körök 1886. évi bordeaux-i kereskedelmi oktatási kongresszus agitációjára végül az 1889. július 15-én kelt új véderőtörvény megadta az egyéves önkéntességi kedvezményt. $\mathrm{E}$ szerint minden oklevéllel rendelkező növendéket szabadságolták egy évi katonai szolgálat után, ha nyilvános jogú felső kereskedelmi iskolában végzett (Borotvás-Nagy, 1928. 215. o.).
} 
osztályozták a diákokat. A tanulók első négyötöde, akik elérték a maximális pontszám legalább 65\%-át egy katonai záradékkal ellátott oklevelet, míg a fennmaradt egyötöd (55-65\% eredménnyel végzettek) iskolalátogatási tanúsítványt kapott és három év katonai szolgálattal tartozott (Lenormand, 2008). Ám ez a kedvezmény csak 1906-ig volt érvényben, ugyanis Clemenceau miniszterelnöksége idején a kétéves katonai szolgálatot három évre emelték, valamint az egyéves önkéntességet megszüntették és a tanulók számára is kétéves szolgálatot tették kötelezővé. A rendeletben szabályozták, az egyéb szakiskolák mellett, a kereskedelmi iskolák múködését is. Bár készült egy, a képzési struktúra alapját meghatározó - fentiekben jelzett - közös tanterv, azonban a rendelet szinte teljes körû́ autonómiát biztosított az iskolák fenntartóinak, lehetővé téve számukra, hogy tantervüket, szervezetüket és vizsgálati rendtartásukat az adott vidék igényei szerint állítsák össze. Egyúttal megvonták az iskolatípus végzettjeitől az egyéves katonai önkéntességet (Szántó, 1925). Megmaradt ugyan a szakfelügyelők szórványos látogatása, azonban a felső kereskedelmi iskolák autonóm intézményként múködhettek, döntően a helyi szükségletek szerint alakították képzésük tartalmát. Amíg a magyar iskolákat egyfajta egyetemesség (egységes képzési struktúra) jellemezte, addig a francia intézményeket a specialitás (a képzés igények mentén történő kialakítása).

\section{KÖZÉPFOKÚ KERESKEDELMI SZAKOKTATÁS MAGYARORSZÁGON}

Míg az 1850-es évek előtt a vasárnapi iskolák határozták meg a hazai szakoktatás jellegét, addig a század közepétől egyre nagyobb hangsúlyt kapott a középfokú szakképzés, melynek első fontos állomása 1857-ben a Pesti Kereskedelmi Akadémia megnyitása volt. A polgári kereskedőknek a tanoncoktatás tekintetében megfogalmazott igényei a nagykereskedők számára már nem bizonyultak elegendőnek. A nagykereskedők, akik testületté 1846-ban szerveződtek, nem elégedtek meg az elemi, polgári, magán, illetve egyes alreáliskolák szakképzési színvonalával, valamint ezen iskolák nyújtotta végzettségek társadalmi presztízsével. Az 1850-es évek közepén a nagykereskedők már nyíltan is szót emeltek egy a fentiekben már említett Höhere Handelsschule, azaz egy középfokú felsőbb kereskedelmi iskola megalapítása mellett (Pólya, 1896. 146. o.). A Nagykereskedők 1856. évi választmányi ülésén Appiano József, a Pest-Budai Kereskedelmi és Iparkamara elnöke felszólalásában rámutatott arra, hogy ha az állam nem tesz semmit, akkor magának a testületnek kell lépnie a középfokú kereskedelmi szakoktatás megszervezése érdekében, akár vállalva az ezzel járó anyagi terheket is. Appaino mintaként a lipcsei, a drezdai, a brünni és a laibachi iskolát mutatta be. Végül a nagykereskedők testülete egy bizottságot állított fel, melynek tagjai (Fusch Rudolf, Weiss Bernát, Kochmeister Frigyes mellett, az ipartanodai tanárok is képviseltették magukat Bidermann Ferenc, Fritsch 
Vilmos, Conlegner Károly) feladatul kapták, hogy a külföldi - elsősorban német - iskolák tanulmányozása után dolgozzák ki egy középfokú kereskedelmi iskolatípus alapításának és szervezetének a tervét (Vincze, 1937. 64-65. o.).

A külföldi iskolák közül leginkább az 1831-ben August Schiebe által alapított, lipcsei intézmény (Handelsrealschule) felelt meg a hazai igényeknek, melynek célkitúzéseiben a gyakorlati képzés fontossága mellett, az általánosan múvelő tárgyak is jelentős szerepet kaptak, ez utóbbi a nagykereskedők számára kiemelten fontos volt, mivel így fiaik a szakma elsajátítása mellett a társadalmi hierarchiában is feljebb léphettek (Rätzer, 2001. 18-19. o.). Azonban, amíg a tantárgyfelosztás, a szervezeti szabályzat mintájául a kezdetben célként megfogalmazott egy vagy két évfolyamos, a szakmai képzést előtérbe helyező német felsőbb kereskedelmi iskola (Höhere Handelsschule) helyett, az Entwurf és a lipcsei Handelrealschule tanításterve szolgált, addig a leendő iskola elnevezésére az 1856-ban megnyíló prágai Handelsakademie. Végül az új pesti iskola múködési alapelveit és szervezeti szabályzatát a Budapesti Nagykereskedők és Nagyiparosok Társulata és a Pesti Polgári Szabadalmazott Kereskedelmi Testület dolgozta ki, melyet a Helytartótanács 1857. április 17-én határozatával (némi módosítás után) elfogadott (Bricht, 1896. 231. o.). A Pester Handelsakademie (Pesti Kereskedelmi Akadémia) ünnepélyes megnyitására 1857. november 1-én került sor. ${ }^{6}$ A végleges szervezeti szabályzat értelmében két tagozatra oszlott az iskola (akadémia): állt egy felsőbb kereskedelmi tanintézetből (Höhere Handelsschule) és egy kereskedő tanonciskolából (Schulen für Handelslehrlinge). A középfokú kereskedelmi tagozat egy hároméves felső kereskedelmi iskolát, egy kétéves előkészítő iskolát (Vorbereitungsschule), és egy kétéves esti tanfolyamot foglalt magába. Az előkészítő iskolát azok a diákok látogatták, akik a felvétel feltételeinek - amely az alreáliskola három vagy az algimnázium négy osztályának sikeres elvégzését kívánta meg - nem feleltek meg. ${ }^{7}$ A felsőbb kereskedelmi iskola három évfolyamból állt és heti 35-34-33 órában tanulták a diákok az általános és szakmúveltséget adó tárgyakat (Vincze, 1935. 49. o.). Az iskola tanítási nyelve a német volt, majd 1861-től az előkészítő osztályban a magyar és a történelem, míg a felsőbb osztályokban a történelem tantárgy oktatása magyar nyelven folyt. A diákok tanulmányaik végén úgynevezett „elbocsátó-bizonyítványt” kaptak (Schack és Vincze, 1930. 323. o.). A kiegyezés előtt a pesti akadémiához hasonló középfokú kereskedelmi iskola nem volt hazánkban.

A középfokú szakoktatás első intézményének (Pesti Kereskedelmi Akadémia) létrejöttében legalább olyan nagy szerepe volt a gazdasági igényeknek, mint a pesti nagykereskedők társadalmi elismerés utáni törekvésének. Ez utóbbit jelzi,

\footnotetext{
${ }^{6}$ Az akadémia múködésének első tíz évében az Ürményi-féle Bálvány utcai bérház második emeletének 16 szobájában nyert elhelyezést, 1867-ben a fenntartó egyesület megvette a Vilmos Császár út és gr. Zichy Jenő utca sarkán álló házat, ahol 18 évig folyt a tanítás (Vincze, 1935. 41.).

${ }^{7}$ Előkészítő iskolában a következő tárgyakat oktatták: hittan, magyar, német, francia, történelem, számtan, algebra, mértan, mértani rajz, szabadkézi rajz és szépírás.
} 
hogy az iskola múködésének első éveiben a harmadik osztályt elvégző tanulók többségének az apja önálló nagytulajdonos volt, majd maguk is hasonló pályára léptek (56\%), tehát eleinte a társadalmi hierarchiában felfelé törekvő tehetôs nagykereskedőknek volt fontos az iskola, valamint az, hogy fiaik be is fejezzék azt (Bódy, 2006. 767. o.).

Továbbá szintén jelzésértékû, hogy az iskola tanításterve a német felsőbb kereskedelmi iskolákkal szemben az általános múveltségú tantárgyakat magasabb óraszámba tanító német kereskedelmi reáliskola képzési struktúráját követte.

\section{KERESKEDELMI SZAKOKTATÁS A KIEGYEZÉS UTÁN}

Az 1867-es kiegyezést követően a modernizálódó gazdaság egyre több szakképzett munkaerőt igényelt, melynek eredményeként ugyan történt előrelépés a szakoktatásban, ám annak üteme eleinte messze nem elégítette ki a szükségleteket. A magyar gazdaság fejlődésében - a nem mezőgazdasági ágazatokat tekintve - nagyon jelentős szerepük volt a hazánkba érkező és letelepedő külföldi vállalkozóknak, mérnököknek, múszaki és gazdasági tisztviselőknek és szakmunkásoknak (Katus, 2012). A dualizmus idején kezdetét vette a szakoktatási rendszer kialakítása, eleinte az ipari szakoktatásra helyezve a hangsúlyt.

A középfokú szakoktatás megszervezésekor Eötvös József különös figyelmet fordított a német mellett, a francia szakiskolai rendszer feltérképezésére. Az 1860-as évek végétől ösztöndíjak révén több szakembert - pl. Szakkáy Józsefet a kassai, Horváth Ignác múegyetemi tanárt a szegedi ipariskola alapítóját küldött külföldre azzal a céllal, hogy tanulmányozzák a német, francia mellett a belga és az angol alsó- közép- és felsőfokú szakoktatást (Vörös, 2013, Vörös, 2017. 86. o.)). Eötvös a középfokú szakiskolákat a fent említett német mintára önállóan, illetve a gimnáziumokkal és reáliskolákkal összekapcsolva képzelte el. Így elsősorban a reáliskolák és a gimnáziumok felső osztályaihoz csatolt tagozatok feladataként látta volna szívesen a középfokú szakoktatást. A kereskedelmi szaktanfolyamra iratkozott tanulók a helyi gimnázium vagy reáliskola növendékeivel együtt tanulták volna azokat a tárgyakat, melyek mindkét tanfolyamon (gimnáziumi vagy reáliskolai) egyenlő arányban szerepeltek. A középfokú kereskedelemi szakiskola/szaktanfolyam a gimnázium három felső osztálya vagy a reáliskola négy felső osztálya mellett, illetve ezekkel összekapcsolva múködött volna (Eötvös, 1880). A négyéves kereskedelmi tagozat tanulói fel lettek volna mentve számos (klasszikus nyelvi és egyéb humán tárgyak) gimnáziumi, reáliskolai tantárgy tanulása alól, helyettük szaktárgyi órákon vettek volna részt. Eötvös szoros kapcsolatot képzelt el a gimnázium és a kereskedelmi iskola között, nem akart a kereskedelmi iskolából egy a gimnáziumi és szakiskolai tananyagot szinte egyenlő arányban a fiatalokra „erőltető" iskolatípust csinálni, de egyúttal fontosnak tartotta az általános múveltséget, melyet a szakiskola tanulói a gimnázium és reáliskola diákjaival együtt sajátították volna el. Ám végül javaslata, melyet 1870 áprilisában terjesztett az országgyúlés elé, nem 
emelkedett törvényerőre. Eötvös elképzelése és a német szakoktatási rendszer egyes elemei közötti kapcsolódási pontként említhető, hogy a korszakban a német középfokú kereskedelmi iskolák többsége is valamely középiskolával kapcsolatosan múködött. A középfokú kereskedelmi képzés a Höhere Handelsschule iskolatípusban folyt, az intézmények egy része önállóan, míg a másik része valamely reáliskolához vagy reálgimnáziumhoz (Königliche Realschule mit Handelsabtheilung, Realgymnasium nebst Handelsschule) kapcsolva múködött. Míg az önálló iskolák két, három vagy hat évfolyamosak voltak, addig az előbbi kapcsolatos iskolák csak az utolsó két évben nyújtottak szakképzést (tulajdonképpen a reáliskolai tanulmányaikat egészíthették ki a tanulók egy két éves kereskedelmi tanfolyammal). ${ }^{8}$ Az osztrák kereskedelmi iskolák ugyan nem a középiskolákkal kapcsolatosan múködtek, de a középfokú akadémiáknak volt egy két évfolyamos előkészítő tagozata, melyet azoknak szánták, akik a középiskolának csak az alsó tagozatát végezték el.

Eötvös halála után Trefort Ágoston került a Vallás- és Közoktatásügyi Minisztérium élére, aki folytatta elődje oktatáspolitikáját, melyben közgazdasági szemléletének is köszönhetően kiemelt szerepet kapott a szakoktatás. Céljai között szerepelt az ipari és kereskedelmi pályák megkedveltetése és az ehhez szükséges képzési hálózat kiépítése. Meglátása szerint Anglia, Franciaország és Németország kell, hogy mintául szolgáljon Magyarországnak, ami az ipart, az iparmúvészetet, a tudományt és a közoktatást illeti (Mann, 1982). Trefort 1872. október 10-én kiadta a kereskedelmi iskolák első hivatalos szervezeti szabályzatát. A három évfolyamos közép kereskedelmi iskolákra vonatkozó szabályzat rendtartása a következőket tartalmazta: ,a három osztályú kereskedelmi tanintézet nyilvánossági joggal ruháztatik fel: ez intézet e mellett fógimnázium vagy a föreáltanodával egyenlö rangba helyeztetik, s mindazon kedvezményekben részesül, melyek ezen intézeteket törvény szerint megilletik: például, hogy az itt végzett növendékek katonai kötelezettségük kitöltésében az egy évi önkéntességre jogositva vannak" (Schack és Vincze, 1930. 359. o.). A közép kereskedelmi iskolába azok a tanulók jelentkezhettek, akik elvégezték a gimnázium, a reál, vagy a polgári iskola negyedik osztályát, illetve azok a fiúk, akik betöltötték a 14. életévüket és a felvételi vizsgán megfeleltek. A felsőbb kereskedelmi iskolákról, mint a későbbiekben megszervezendő iskolatípusról beszélt a szervezet.

A közép kereskedelmi iskolák tanításterve - csekély különbségektől eltekintve - megegyezett a Pesti Kereskedelmi Akadémián érvénybe lévővel, mely a már említett Entwurf der Organisation der Gymnasien und Realschulen (1849) címen kiadott iskolaszervezetnek a reáliskolák alsó tagozatához kapcsolt „Praktische Jahr" egyéves kereskedelmi szaktanfolyamára, valamint a reáliskolák alsó tagozatára vonatkozó előírásokat - néhány tantárgy kiegészítésével - követte. Tehát az első középfokú kereskedelmi iskoláink, mint reáliskolák - azok szellemében

\footnotetext{
${ }^{8}$ Reáliskolával kapcsolatos Königliche Realschule mit Handelsabtheilung: Kaiserlautern, Furth, Landshut, míg Zittauban és Frankfurtban a reálgimnáziummal kapcsolatos kereskedelmi tanfolyam múködött
} 
és előírásai szerint - kezdték meg múködésüket, célul tûzve ki, hogy múvelt kereskedőket neveljenek. Ezért a szakirányú képzés mellett az általánosan múvelő tantárgyak is fontos szerepet kaptak. Bár 1895-ig a középfokú kereskedelmi iskolatípust általában „közép kereskedelmi” elnevezéssel illeti a korabeli pedagógiai szakirodalom, azonban fontos megjegyezni, hogy Magyarországon az 1870-es évektől létrejövő középfokú három évfolyamos kereskedelmi iskolák különböző néven múködtek. Az iskolák egy része az osztrák minta alapján az akadémiai címet viselte, közülük három, alapításától: a társulati fenntartású Pesti Kereskedelmi Akadémia (1857) és a Pozsonyi Kereskedelmi Akadémia (1885), valamint az állami alapítású fiumei kereskedelmi akadémia (1881). A többi hat intézmény 1886 és 1889 között nyerte el ezt a címet, közülük az 1873-ban alapított debreceni és a székesfehérvári iskola (1877) mint kereskedelmi középtanoda, az aradi iskola (1885), mint kereskedelmi középiskola, míg az állami fenntartású soproni (1884) és brassói (1884) iskola alapításakor a fent említett közép kereskedelmi elnevezéssel nyitotta meg a kapuit. Mindemellett 1884-től múködtek a polgári iskolával kapcsolatos kereskedelmi iskolák. A négy évfolyamos polgári iskola az ötödik és hatodik évfolyamon kereskedelmi tanfolyamot szerveztek, illetve 1885-től ezt az utolsó két évet egy harmadikkal egészítették ki, így váltak hároméves kapcsolt kereskedelmi iskolává (kapcsolatos kereskedelmi iskolákról bővebben lásd Nagy A., 2011. 201-218.).

Az 1880-as évek közepétől, ha lassan is, de egyre több közép kereskedelmi iskola és szintén középfokú akadémia nyitotta meg kapuit. A tanulók számának lassú növekedése már 1878 után megfigyelhető, azt követően, hogy a reáliskolákat nyolc osztályossá alakították át, így megnövelve az ott eltöltött tanulóidő hosszát. Ellentétben a reáliskolával, a közép kereskedelmi iskolában a tanulók egy évvel korábban fejezhették be tanulmányaikat, ráadásul az egyéves katonai önkéntességi jog - azaz az úriemberré válás egyik alapvető kritériuma - így is biztosítva volt a diákoknak. Az önkétességi jog elnyerése meghatározta az adott fiatal pályájának alakulását, ugyanis nem volt elhanyagolható tényező, hogy egyéves katonai szolgálat után elnyert tartalékos tiszti címmel léphetett-e ki a munkaerőpiacra, vagy csak több, akár 7-11 éves katonai szolgálat után. Ezen három évfolyamos, döntően polgári iskolára épülő iskolatípus által elnyert önkéntességi jog jól jelzi a gazdasági körök korabeli befolyását, akiknek láthatóan sikerült elérni, hogy a gimnáziumi előtanulmányokat egyáltalán nem igénylő kereskedelmi iskola tanulóit is megillesse a fenti kiváltság. Tovább növelte az iskolatípus népszerúségét az 1883-ban elfogadott, a köztisztviselők minősítéséről szóló törvény, amely a közép kereskedelmi iskolát végzett tanulóknak a középiskolát végzettekkel megegyező jogokat biztosított. Mindez azt jelentette, hogy a polgári iskolai végzettség a köztisztviselői alkalmazás szempontjából egyenértékú volt a négy középiskolai végzettséggel, valamint (az általában polgárira épülő) közép(majd felső)kereskedelmi iskolai végzettség a gimnáziumban/reáliskolában szerzett nyolc középiskolai végzettséggel (Nagy, 2000a). 
Tehát az Entwurf ${ }^{9}$ által az 1850-es években kialakított középiskolai képzést szélesítette ki Trefort, az elsősorban gyakorlati pályákra felkészítő közép kereskedelmi iskolákkal. A polgári és a reáliskola mellett a közép kereskedelmi iskola sem zárta el a tanulókat a felsőfokú - elsősorban főiskolai - tanulmányoktól, így az iskolatípus középfokon egy újabb mobilitási csatornát jelentett.

A középfokú kereskedelmi szakiskolák életében szintén jelentős változást eredményezett a Wlassics Gyula kultuszminiszterségének első évében a kereskedelmi iskolák negyedik szervezetét tartalmazó rendelet (1895. évi 44.001. sz.) hatályba lépése, melynek értelmében az addig használt eltérő elnevezéseket, mint közép kereskedelmi, kereskedelmi akadémia, felsőbb kereskedelmi iskola megszüntette és egységesen a felső kereskedelmi elnevezést vezette be. ${ }^{10}$

Az országban múködő akadémiák közül (brassói, fiumei, soproni, budapesti, aradi, debreceni, kolozsvári, pozsonyi és székesfehérvári) a budapesti és a kolozsvári tarthatta meg akadémiai címét. Az iskolák címe 1895-tól állandó vita tárgyát képezte. Egyrészt egyesek (kereskedelmi kamarák, testületek) a kereskedelmi helyett a közgazdasági elnevezést látták volna szívesen, azzal érvelve, hogy ezek az iskolák csekély arányban képeznek kereskedőket, másrészt az iskolák azt szerették volna elérni, hogy VKM minden intézménytől vonja meg az akadémia cím használatát, mondván ez megtéveszti a szülőket és munkáltatókat egyaránt, mivel magasabb színvonalat (végzettséget) tulajdonítanak neki.

A még ebben az évben kiadott újabb tantervbe két új kötelező tantárgy került beemelésre, a hittan, illetve francia mintára az irodai gyakorlat. Megfigyelhető továbbá a természettudományokkal szemben az idegen nyelv (a francia mellett angolt és olaszt is taníthattak második idegen nyelvként) és a kereskedelmi szaktárgyak óraszámának növekedése.

A nagy hangsúlyt kapó, általában iskolai keretek között megszervezett irodai gyakorlat (a gyakorlati bevezetését követően kevéssé hasonlított a francia „mintára”, mely részben terepen történő gyakorlatot foglalt magába), illetve a kereskedelmi ismeret és levelezés két önálló tárggyá válása már előrevetítette, hogy a kereskedelmi iskolák sokkal inkább kívánnak tisztviselőket, mint kereskedőket képezni.

Az 1895-ös tanterv előírása szerint 17 tantárgyat tanítottak, elsőben heti 32, másodikban és harmadikban pedig heti 34 órában (ez a három évfolyamon 100 órát tett ki hetente). Ez azt jelentette, hogy délelőtt és délután egyaránt volt tanítás, ami így nem kis feladatot és leterheltséget jelentett a növendékeknek. A kereskedelmi iskolák alsó osztályában 13 rendes (szépírással együtt) tantárgyat 33 órában, a középső és felső osztályban 14-et 34 órában tanítottak, ehhez

\footnotetext{
${ }^{9}$ Entwurf 1849-ben szervezetileg is elválasztotta a közép- és felsőfokú oktatást, egyszersmind kialakította a hagyományos elitképző klasszikus humán képzést adó tanulmányokat érettségivel záró nyolcosztályos gimnáziumot és hatosztályos praktikus képzést adó reáliskolát.

10 A felső kereskedelmi iskolák hivatalos szervezete. Kiadta a kereskedelemügyi m. kir. miniszter hozzájárulásával a vallás- és közoktatásügyi m. kir miniszter 1895. évi augusztus hó 20-án 44.001. sz. alatt kelt. rendeletével. M. kir. Tud. Egyetemi Nyomda, Budapest, 1895. 60.
} 
társultak még rendkívüli tárgyak, amelyekkel együtt a heti óraszám elérte a 35-36 órát. Ezzel szemben a középiskolák felső osztályában 8 rendes tantárgyat a heti 2 óta testneveléssel együtt 30 órában oktattak (Koltai, 1899. 101. o.). A felvételi vizsgát megszüntették, helyette a felvétel feltétele négy középiskolai vagy polgári osztály elvégzése volt. Az 1895-ben elfogadott rendelet előírásának megfelelően a diákok tanulmányaik végén tett záróvizsgáját hivatalosan is érettséginek nevezték. ${ }^{11}$

A hazai középfokú kereskedelmi iskolák száma 1885-ben 17, amely 1895-re 35-re növekedett. Ezek közül 13 állami, 5 államilag segélyezett községi, 5 községi vagy városi, 1 felekezeti, 6 testületi vagy társulati és 5 magán fenntartású volt. A tanulók száma 1857-től, az első iskola megnyitásától (a Pesti Kereskedelmi Akadémia 66 tanulóval kezdte meg múködését), kezdve folyamatosan emelkedett 1895-re elérve a 4983 főt.

Ez a közel 5000 fős létszám megközelítőleg a fele volt az 1895-ben a gimnáziumok és reáliskolák három felső osztályába beiratkozott (10 291 fő) tanulóknak. ${ }^{12}$ A 19-20. század fordulóján 37 középfokú kereskedelmi iskola múködött Magyarországon, melyek közül 6 a fővárosban, míg 31 vidéken. ${ }^{13}$ A felső kereskedelmi iskolák többsége magyar (35), míg egy román (Brassó) és egy részben olasz (Fiume) tannyelvú (Schack, 1903. 50. o.). A felső kereskedelmibe járó tanulók létszáma 1880 (688 fő) és 1910 (8308 fő) között több mint tízszeresére nőtt, sőt megközelítette 1910-re a reáliskolába járók számát (amely ekkor 10.668 fő volt) (MSÉ, 1910. 158).

A középfokú kereskedelmi iskolákat szabályzó 1872-es rendelet értelmében az intézmények feletti felügyelet a Földmíves- Ipar- és Kereskedelmi Minisztérium hatásköre alól a Vallás- és Közoktatásügyi Minisztérium alá került. A közép kereskedelmi iskolák felügyelete ideiglenesen a népiskolai tanfelügyelők alá került, majd közvetlenül a VKM hatáskörébe tartoztak. Az 1895-ben az iskolák felügyeletét illetően is történt változás, ugyanis ettől kezdve az iskolák a népiskolai tanfelügyelők hatásköre alól a felső kereskedelmi iskolai főigazgató igazgatása alá kerültek (Felkai, 1994. 118. o.).

\footnotetext{
11 Korábban csak a pesti akadémián szerzett végbizonyítványra (1869-től) használták az érettségi elnevezést, a többi középfokú kereskedelmi iskolában a tanulók az 1872-es, 1884-es és 1885-ös szervezet szerint is záróvizsgát tettek, amely bizonyos tekintetben egyenértékû volt az érettségivel.

12 A közép kereskedelmi iskolák népszerúségét jelzi, hogy már 1892/93-as tanévben is az országban múködő 23 reáliskola három felső osztályát látogató 1379 fôs tanulói létszám 2284 fôvel kevesebb volt, mint a közép kereskedelmi iskolák diákjainak száma (3663fő). Amíg a reáliskolák felső osztályainak tanulói létszáma 329 fő, addig a kereskedelmi iskolák felső osztályaiban 902 fő tanult, tehát megközelítőleg háromszor annyian jártak ez utóbbi iskolatípus végzős évfolyamaira (Kereskedelmi szakiskoláink, 1893. 217. o.; Schack, 1903. 49. o.).

13 A felső kereskedelmi iskolákhoz hasonló felső ipariskolák száma mindössze három volt.
} 


\section{Az ÁltAlÁNOS ÉS A SZAKMÚVELTSÉGET ADÓ TANTÁRGYAK MEGOSZlÁsA A MAGYAR, A NÉMET, AZ OSZTRÁK ÉS A FRANCIA KERESKEDELMI ISKOLÁKBAN}

Összehasonlítva a négy $(1857,1872,1885,1895)$ magyar tanítástervet elmondható, hogy az 1857-es és 1872-es alapvetően a reáliskolai tantervet tükrözte, hiszen az 1857-es tanítástervben egyenlő arányban (17\%) szerepeltek a reáliskolai természettudományi tantárgyak és a kereskedelmi szaktárgyak, illetve 1872-ben a reál és közmúveltségi tárgyak száma egyaránt csökkent, míg a szaktárgyak aránya emelkedett (Nagy, 1998. 671. o.).

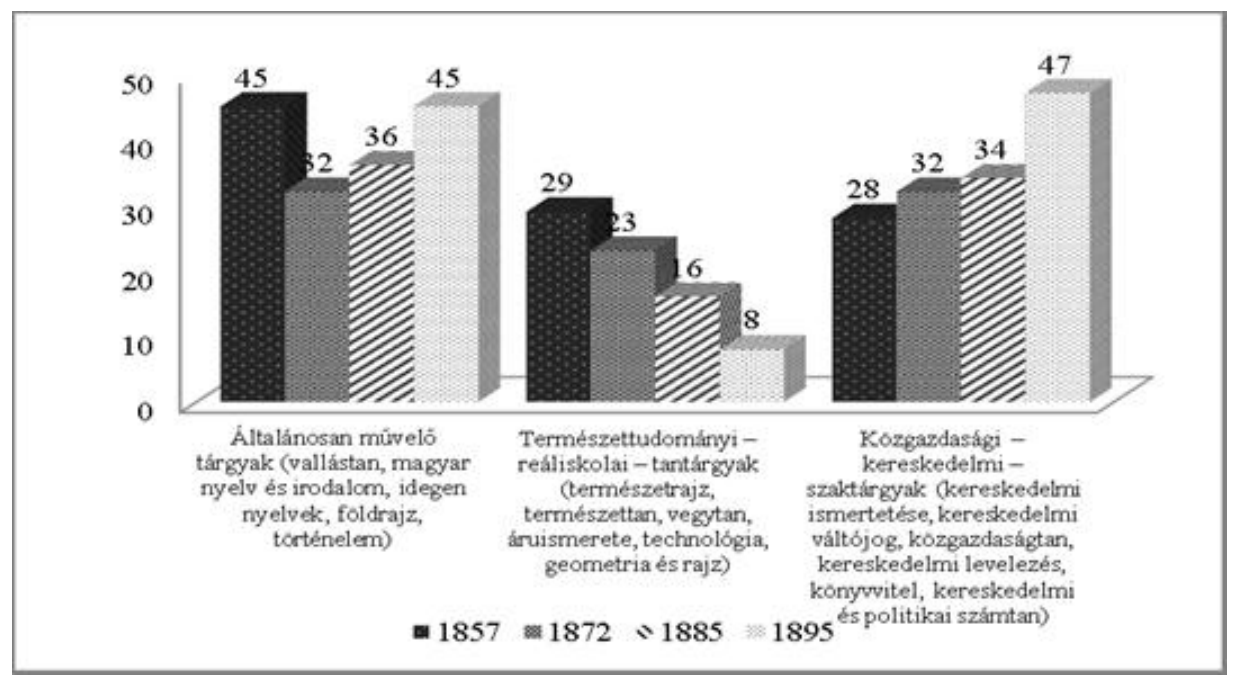

1. ábra. Az általánosan müvelö, a természettudományi és a közgazdasági (kereskedelmi) tárgyak összes óraszáma az 1857-es, 1872-es, 1885-ös, és az 1895-ös tanitási tervekben

Forrás: Schack-Vincze, 1930. 255. o.; Vincze, 1935. 268. o.; Szervezeti szabályzatok $(1857,1872,1885,1895)$

Ám miután a reáliskolákhoz hasonlóan a kereskedelmi iskolák esetében is egyre fontosabbá váltak a közmúveltségi tantárgyak (mely az iskolatípus társadalmi elfogadását növelhette), úgy az előbbiekben említett irány megfordult és az 1885-ös tanítástervben már közmúveltségi tárgyak aránya gyorsabban nőtt, mint a szaktárgyaké. Így nem meglepő, hogy a kereskedelmi vállalkozók, kamarák és testületek képviselői gyakran sérelmezték a szakmai, főleg gyakorlati képzés hiányát (lásd részletesebben: Nagy A., 2015).

A négy tanítástervet tekintve az óraszámokban bekövetkező változások jól jelzik az iskolatípus jellegének átalakulását: természettudományos (reáliskolai) 
tantárgyak óraszáma jelentősen csökkent (29-23-16-8), míg a szaktárgyaké emelkedett (28-32-34-47) (Vincze, 1935. 255. o.). Az 1895-ös tantervben a szaktárgyak aránya $47 \%$, de ekkor már a közmúveltségi tárgyak aránya is elérte $45 \%$-ot, míg a reáliáké 8\%-ra csökkent (Nagy, 1998. 671. o.).

Az érettségihez elengedhetetlenül fontos közmúveltségi tárgyak arányának növekedése (a fent említett hittan tantárgy kötelezővé tétele, a felvételi megszüntetése... stb.) egyértelmúen a felső kereskedelmi iskoláknak a középiskolákhoz való közeledési szándékát jelezte. Az 1895-ös tanterven már érződik a kereskedelmi körök befolyása a tantervkészítésre (kereskedelmi iroda tantárgy bevezetése), az államhatalom, illetve Wlassics Gyula oktatáspolitikai alapeszméje: a szellemi kultúra által megerősítendő egységes magyar nemzet megteremtésére való törekvés, melynek egyik eszköze lehet a középfokú oktatás tekintetében a középiskola (gimnázium, reáliskola) mellett, a kellő általános múveltséget (,középiskolákban érvényre juttatni a tananyag nemzeti tartalmát”) biztosító felső kereskedelmi iskola is (Felkai, 1994. 18. o.). Amíg az első szervezet egyéves önkéntességet biztosított, a második hat év alatt kereskedelmi pályára képesített, addig a harmadik hét év alatt érettségi bizonyítványt adott, hogy ezt követően az 1883-as a köztisztviselők minősítéséről szóló törvény révén ne a kereskedelemre, vagy ezzel rokon szakokra készítsen fel, hanem 70-80\%-ban tisztviselőket képezzen.

A második és a harmadik ábrára tekintve láthatjuk, hogy az általános múveltséget adó tantárgyak óraszáma 1885-ben az egyes német és osztrák iskolák többségében a hazai iskolák e tárgykörre fordított 36 tanóráját is meghaladta (44-55 óra), itt megjegyzendő, hogy ez utóbbi 1895-től hazánkban is elérte a 45 órát. A szaktárgyak óraszámát vizsgálva elmondható, hogy hazánkban a szaktárgyak óraszáma 1885-ben átlag 34 óra volt, a híres bécsi és prágai kereskedelmi akadémián ugyanerre a tárgykörre mindössze két órával jutott több (36 óra), míg Lipcsében csak 21 tanórát szántak a kereskedelmi tárgyakra. Tehát a német-osztrák kereskedelmi iskolákban sem volt lényegesen magasabb a szaktárgyak óraszáma.

A kor szellemének megfelelően a magyar középfokú kereskedelmi iskolákban ugyan hangoztatták a szaktárgyak hasznos és szükséges voltát, ám az általános múveltségú tárgyakkal szemben, amelyek a „múvelt emberré nevelés" biztosítékai voltak, a szaktárgyaknak mindig is másodlagos szerep jutott. Az általános múveltség fontos volt azoknak a többségében vagyonos nagykereskedőknek is, akik megengedhették maguknak, hogy fiaikat drága pénzen magasabb fokú kereskedelmi iskolába küldjék. A reáliskolákhoz hasonlóan kereskedelmi iskolában oktatott általánosan múvelő tárgyak kellő óraszáma tette lehetővé tulajdonképpen azt, hogy a pesti akadémia végzett diákjai 1868-ban elnyerték az egyéves katonai önkéntesség jogát.

\footnotetext{
${ }^{14}$ Mivel a magyar középfokú kereskedelmi szakoktatást jellemző egységes szervezet a német, az osztrák és a francia 19. századi szakképzés során nem vagy csak kevéssé valósult meg, így ez
} 


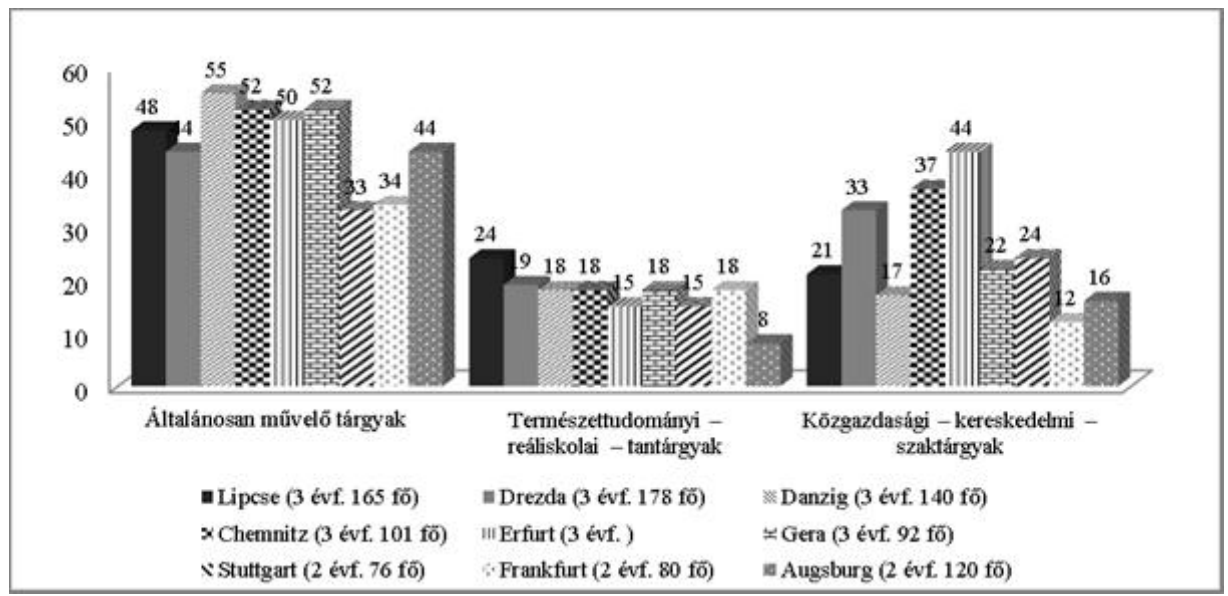

2. ábra. Az általánosan müvelo, a természettudományi és a szaktárgyak összes óraszáma az egyes német kereskedelmi iskolákban a teljes képzési ido" alatt 1885-ben.

Forrás: Jourdan-Dumont, 1886. 10-21.; 26-45. o. ${ }^{14}$

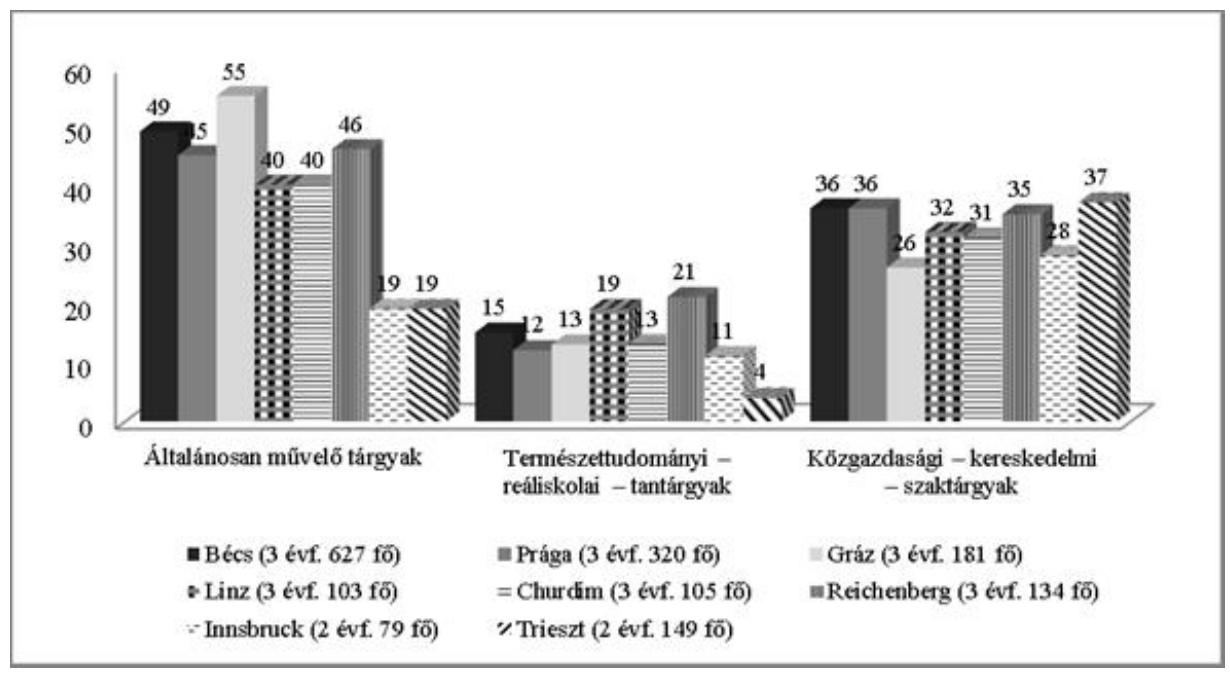

3. ábra. Az általánosan müvelo, a természettudományi és a szaktárgyak összes óraszáma a képzés során az egyes osztrák iskolákban 1885-ben.

Forrás: Jourdan-Dumont, 1886. 95-116.; 121-131. o.

A kifejezetten a kereskedelmi pályára felkészítő szaktárgyak óraszáma a hazai kereskedelmi kamarák képviselői által gyakran hivatkozott francia iskolák-

utóbbiak esetében egy-egy jelentősebb kereskedelmi iskola tantárgy és órafelosztását vizsgáltuk meg. 
ban haladta meg az általános múveltséget adó tárgyakét, így Franciaországban elsősorban - a magyar gazdasági körök és az egyes hazai társulati fenntartású akadémiák tanárai által is gyakran hiányolt - szakképzést és a gyakorlati oktatást helyezve előtérbe (ld. 4. ábra).

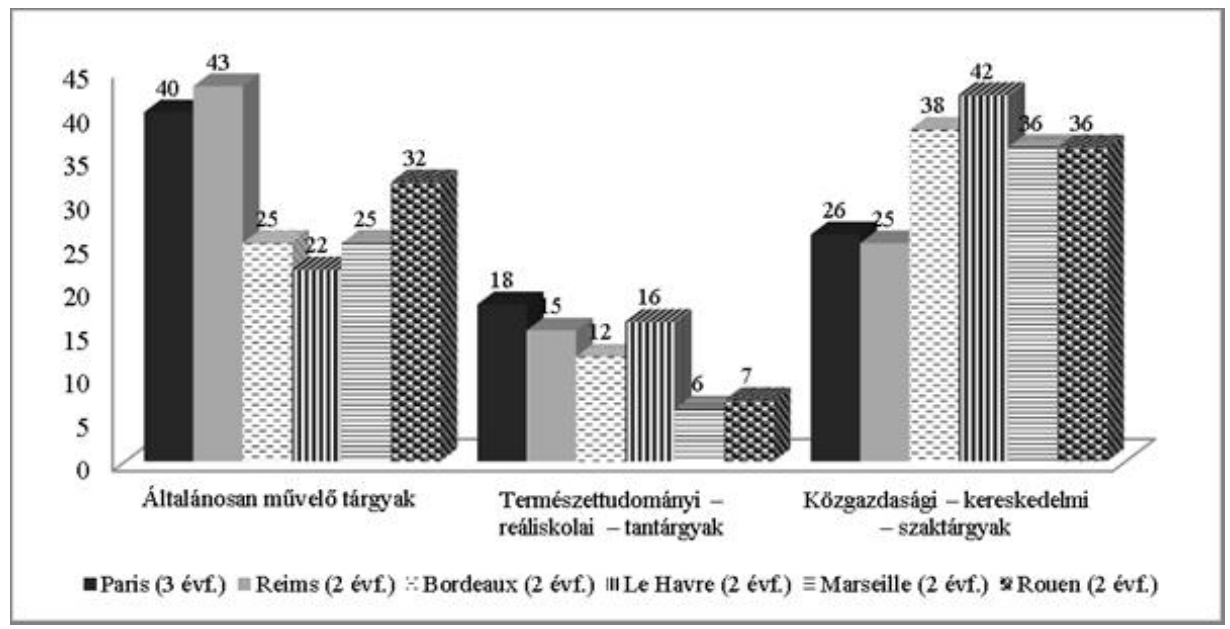

4. ábra. Az általánosan müvelo", a természettudományi és a szaktárgyak összes óraszáma a képzés során az egyes francia iskolákban 1885-ben.

Forrás: Léautey, 1886.; Varga, 1890. 38-60. o.

A képzés tartalmát illetően a német mintára szerveződő magyar kereskedelmi iskolákban a tantárgyak alig tértek el a német, osztrák és a francia iskolákban tanított tárgyaktól, azonban amíg Magyarországon 1872-től egy, a VKM által rendeletbe foglalt szervezeti szabályzat szerint szerveződött az oktatás (tartalma, óraszáma, képzés ideje), addig ilyen egységes jellegú képzés a fent említett országok esetében nem volt. Ugyan történtek lépések a képzés egységes szabályzására vonatkozóan, azonban a hazaihoz hasonló a képzési rendszerről még az 1898 utáni Franciaországban sem beszélhetünk. A német, osztrák és francia állam csakúgy, mint a magyar adott bizonyos kedvezményeket (katonai önkéntességi jog), illetve államsegélyt, de kereskedelmi iskolát nem vagy csak csekély számban alapított (tartott fenn) és nem szólt bele a képzés tartalmába. Így a három évfolyamos középfokú iskolák között olykor jelentős eltérés volt, különösen igaz ez Franciaország esetében, ahol az 1898-as rendeleti szabályozás után az iskolák továbbra is szinte teljes autonómiával rendelkeztek, így képzésük tartalmát a gazdasági igények mentén, az adott régióban meghatározó mezőgazdasági vagy iparágak igényeivel igyekeztek összhangba hozni. Ez utóbbi mintára történő képzési struktúra kialakítására a gazdasági szektor képviselői részéről hazánkban is megfogalmazódott az igény, azonban a nemzetiségi és egyéb érdekeket előtérbe helyező oktatáspolitika részéről nem talált támogatásra. 
Míg az idegen nyelvek közül hazánkban a német és a francia, addig a német iskolákban a francia és az angol, valamint a mennyiségtan tantárgy kapott kiemelt szerepet. A magyar és az osztrák iskolákban hangsúlyos vegytan a német iskolákban nem élvezett prioritást, ellenben a testi, főleg kézi ügyesség fejlesztésének nagyobb figyelmet szenteltek (testgyakorlás, rajz, szépírás). A magyar iskolákat a munkaerőpiac képviselői és az érettségi biztosi minőségükben jelentést tevő kereskedelmi és iparkamarai tagok részéről gyakran érte az a vád, hogy a tanulók idegen nyelvtudása (elsősorban a német) a kereskedelemhez szükséges egyszerúbb szövegértési szintet sem éri el. Ha összehasonlítjuk a nyelvi órák számát a német és az osztrák iskolákkal, láthatjuk, hogy hazánkban nem csak a módszertani hiányosságok állhattak a rossz eredmények háttérében, hanem az óraszám csekélyebb száma is, mivel a bécsi akadémiát követően hazánkban volt legalacsonyabb a nyelvi órák aránya.

1. táblázat. Idegen nyelvi órák és a mennyiségtan tantárgy aránya az iskolák összes óraszámához viszonyítva 1885-ben

Forrás: Ábrai, 1887. 15-19. o.; Jourdan-Dumont, 1886.

\begin{tabular}{|l|l|l|l|l|l|}
\hline $\begin{array}{l}\text { Város/ } \\
\text { iskola }\end{array}$ & $\begin{array}{l}\text { Képzés } \\
\text { ideje } \\
\text { év }\end{array}$ & Nyelv/tanulmány ideje & Nyelvek \% & $\begin{array}{l}\text { Mennyiség- } \\
\text { tan }\end{array}$ & $\begin{array}{l}\text { Összes tanóra } \\
\text { átlagos heti } \\
\text { óraszám \% }\end{array}$ \\
\hline Magyarország & 3 & német, francia 3 év & 20,9 & 18,6 & 28,7 \\
\hline Marktbreit & 6 & francia 6 év, angol 2 év & 21,2 & 21,8 & 30 \\
\hline Nürnberg & 6 & francia 6 év, angol 3 év & 23,5 & 22,3 & 30 \\
\hline Drezda & 3 & francia, angol 3 év & 23,7 & 20 & 33,8 \\
\hline Lipcse & 3 & francia, angol 3 év & 23,8 & 18,5 & 36,3 \\
\hline München & 6 & francia 6, angol 4 év & 24,5 & 18,3 & 33,3 \\
\hline Chemnitz & 3 & francia, angol 3 év & 25,7 & 18,3 & 36,3 \\
\hline Erfurt & 3 & francia, angol 3, olasz 2 év & 26,5 & 18 & - \\
\hline Stuttgart & 2 & francia, angol 2 év & 29 & 18,4 & 35,2 \\
\hline Berlin & 6 & francia 6, angol 4 év & 29,3 & 16,8 & 33,1 \\
\hline Gera & 3 & francia, angol 3 év & 29,8 & - & - \\
\hline Frankfurt & 2 & francia, angol 2 év & 30 & 13,7 & 36,5 \\
\hline Bautzen & 2 & francia, angol 2 év & 32,3 & 16,2 & 34 \\
\hline Augsburg & 2 & francia, angol 2, olasz 1 év & 34,7 & 17,7 & 34 \\
\hline Danzig & 3 & francia, angol 3 év & 41 & 18 & 33,3 \\
\hline
\end{tabular}

A hatosztályos német iskolákban a francia nyelvet hat évfolyamon keresztül tanították, míg a három évfolyamos iskolákban a bekerülés feltétele a kellő nyelvtudás felvételi vizsgán való bizonyítása volt, ezzel szemben Magyarországon a döntően polgári iskolából érkező tanulók francia nyelvet nem tanultak, így új nyelvként kellett három év alatt elsajátítatniuk. Ráadásul egy német (kereskedelmi) iskolai osztályba átlag 20-25 fő járt (de volt intézmény ahol ennél is kevesebb, a híres lipcsei iskolában max. 12. fő volt egy osztályban), mely a hazai 35-40 olykor 60 fős osztályokhoz képest sokkal inkább segítette az eredményes nyelvtanulást. A német kereskedelemi iskolák többségében egy lakószobánál nem nagyobb helységben 4-5 régi szerkezetú padban ültek a diákok (minden 
padban 4 fő), melyek egészen közel voltak a tanári katedrához (Ábrai, 1887. 23. o.). Így a német nyelvtanár egész órán társalgási hangerőn kommunikálhatott a tanulókkal, akik az utolsó padból is jól látták és hallották őt, ráadásul minden órán akár minden tanulóval tudott foglalkozni, így volt lehetősége megismerni, többször feleltetni diákjait, szemben magyar kollégáival, akik az 40-50 fős osztályokban csak egyszer vagy kétszer tudták felmérni tanulóik tudását.

2. táblázat. Az egyes tantárgyak aránya az összes tanóra óraszámának arányában 1885-ben. Forrás: Ábrai, 1887., Jourdan-Dumont, 1886.

\begin{tabular}{|l|l|l|l|}
\hline Iskola & Nyelvek\% & Mennyiségtan \% & Könyvvitel \% \\
\hline Bécs & 20 & 20 & 15,3 \\
\hline Churdim & 22,9 & 18,8 & 14,6 \\
\hline Graz & 34,3 & 19,5 & 20,6 \\
\hline Linz & 21,9 & 17,7 & 12,5 \\
\hline Prága (német) & 24,4 & 13,8 & 11,7 \\
\hline Prága (cseh) & 25,5 & 11,7 & 11,8 \\
\hline Magyarország & 20,9 & 18,6 & 16,2 \\
\hline
\end{tabular}

Az idegen nyelvek óraszámának aránya 1885-ben a két évfolyamos francia iskolák többségében szintén magasabb (Párizs 30\%, Rouen 36\%, Marseille 37\%, Reims 36\%, Bordeaux 29\%, Le Havre 18\%) volt, mint hazánkban (20,9\%) (Varga, 1890, Jourdon-Dumont, 1886).

A természetrajzot valamennyi osztrák intézményben magasabb óraszámban tanították, mint hazánkban. Szintén különbség, hogy az osztrák iskolákban már ekkor a kötelező tantárgyak között szerepelt a gyorsírás, míg nálunk legfeljebb a szabadon választhatóak között. Sőt az osztrák iskolák gépírást is tanítottak, míg nálunk ezt a legtöbb iskolában az 1880-as évektől nem oktatták.

\section{ÖsSzEGZÉs}

Összességében elmondható, hogy a magyar középfokú kereskedelemi iskolák, míg szervezetüket (képzés tartalma, felépítése) tekintve a német mintát követték, addig elnevezésüket illetően eleinte az osztrák iskolák viselte akadémia címet használták, azonban megjegyzendő, hogy a mintaként szolgáló osztrák akadémiák egy előkészítő képzést követően magasabb előképzettségú tanulókat vettek fel. Magyarországon, csakúgy, mint Németországban, több kapcsolatos kereskedelmi iskola múködött, ám azok képzési minősége messze elmaradt a német iskolákétól.

A német, osztrák, francia és magyar kereskedelmi iskolákban a tanítandó kereskedelmi szaktárgyak óraszáma a munkaerőpiac képviselői és az iskolák fenntartói részéről egyaránt komoly vita tárgyát képezte a korszakban. Amíg az általánosan múvelő tárgyakat előnyben részesítő német és osztrák iskolák 
az előbbi tárgykörbe sorolható idegen nyelvekre helyezték a hangsúlyt, addig a magyar iskolákban a nyelveket alacsonyabb óraszámban tanították, ráadásul mind a tanulók előképzettségének, mind a szaktanárok szakmai felkészületlenségéből adódóan a magyar tanulók az idegen nyelvi készségeiket illetően komoly hátrányokkal zárták tanulmányaikat. Nem volt ritka, hogy a tehetősebb magyar családok a hazai kereskedelmi iskolák valamelyikében tanuló fiaikat nyelvgyakorlás és a gyakorlati nemzetközi kereskedelemmel való megismerkedés céljából a hazai kereskedelmi iskola elvégzése után egy-egy német vagy a szakmai tárgyakat magas óraszámba tanító francia intézménybe küldték tanulni.

Hazánkban a kereskedelmi iskolák száma több volt, azonban a kereskedelmi szakképzés minősége az iskoláink többségében nem érte el a német és francia iskolákét. A végzett magyar tanulók a munkaerőpiacon viszonylag gyors elhelyezkedésre számíthattak, azonban a munkáltatok gyakran sérelmezték, hogy hosszabb betanításra volt szükség. Bár a hazai gazdasági, kereskedelmi körök több esetben állították példaként - a hazai tanári szakma képviselői által több alkalommal is tanulmányozott és a korabeli kereskedelmi szaksajtóban bemutatott - a képzést az adott régiók gazdasági igényei szerint alakító francia kereskedelmi szakoktatás rendszerét, azonban annak gyakorlati elemei nem kerültek átemelésre. ${ }^{15}$ Ugyan az irodai munkálatok tantárgy beemelése francia mintára valósult meg, ám a gyakorlatias jellege már kevéssé érvényesült.

A német, osztrák és francia középfokú kereskedelmi iskolák többségét gazdasági érdekeltségek alapították és tartották fenn, így volt ez a 19. század közepén hazánkban is. Ám amíg ez a fent jelzett országokban az arányokat tekintve döntően így is maradt, addig Magyarországon az 1880-as évek közepétől sorra nyíltak az állami, községi fenntartású iskolák. Az első állami felső kereskedelmi iskola 1881-ben Fiumében nyitotta meg kapuit. Az intézmény megszervezése mögött politikai szándék is húzódott, ugyanis az iskola a térség magyarosításának egyik eszköze volt. A nemzetiségi kérdés mellett, a tananyagában a középiskolákhoz közelító állami felső kereskedelmi iskolák létrehozásával (egyszersmind társadalmi presztízsének növelésével) tovább csökkenthette az oktatáspolitika a (felső)középfokú oktatás felekezeti jellegét, egyúttal növelve az állami befolyást a középfokú oktatás terén úgy, hogy mindez a klasszikus felekezeti gimnáziumokat nem érintette (Nagy, 2000b). Egyrészt a polgári, az alsó és felső reáliskolák, valamint a felső kereskedelmi iskolák számát igyekeztek emelni, ezzel figyelembe véve a társadalmi igényeket is, másrészt a tantervpolitika segítségével a felekezeti középiskolákban növelték a nem felekezeti „erők” részvételét. Ennek eredményeképpen az oktatáspolitika a felekezeti iskolák államosítása és túlszaporítása nélkül az alsó-középiskolai piacon megszüntette, míg a felső középiskolák esetében csökkentette a felekezetek dominanciáját (Nagy, 2000b. 95. o.). Az 1890-es évek közepétől kapuikat az állam támogatásával

15 MNL OL KM K231. 138. doboz. 4. tétel, Az egyes kereskedelmi és iparkamarák által megküldött jelentések a kereskedelmi szakoktatás megreformálása tárgyában 1890-1894. 
megnyitó felső kereskedelmi iskolák többsége a nemzetiségek lakta területeken nyílt, ${ }^{16}$ igyekezve érvényre juttatni Wlassics Gyula a népiskolák estében is jól ismert azon alapeszméjét, hogy a nemzet jövőjét a magyarság túlsúlyára kell alapozni és ezt elsősorban szellemi kultúrája biztosíthatja. ${ }^{17}$

A katonai önkéntesség és egyéb jogok az osztrák, német és francia iskolák esetében is befolyásolták látogatottság alakulását - ám annak feltételrendszere, majd átalakítása, egyes helyeken való későbbi megvonása miatt -, azonban közel sem oly mértékben, mint hazánkban. A fent említett országok esetében több alkalommal történt kísérlet rendeletek, törvények által a középfokú képzés állam által történő egységesítésére, azonban e rendelkezések gyakorlatban történő betartása - a 19. század végén - még kevéssé valósult meg (ha az iskolák részesültek is állami támogatásban és/vagy volt közös szervezetük, rendtartásuk, mint az osztrák iskoláknak, azonban többségük 1920 után is magánfenntartású maradt és viszonylag széleskörú autonómiával rendelkezett, mint például a francia iskolák). Tehát a magyar kereskedelmi szakoktatás szerkezetét tekintve (képzés ideje, tartalma) elsősorban német-osztrák mintára szerveződött, azonban az egységes állami szabályozást követően, az egyes iskolák a képzés tartalmát érintő autonómiájukat elveszíttették, így a munkaerő-piaci igényekhez való igazódás elmaradt. Ez utóbbi a jelzett országok esetében sem önmagában a szaktárgyak óraszámának emelésében nyilvánult meg, hanem a képzés tartalmának folyamatos átalakításában, mely hazánkban elmaradt, így az iskolatípus a végzett tanulók esetleges nemzetközi kereskedelembe való érvényesülését csak kevéssé tudta elősegíteni.

\section{ELSŐDLEGES FORRÁSOK}

A kereskedelmi iskolák szervezete. Vallás- és közoktatásügyi m. kir miniszter 1885. évi augusztus hó 3. napján 29.801. szám alatt kelt rendeletéből. Egyetemi nyomda, Budapest.

A felső kereskedelmi iskolák hivatalos szervezete. Kiadta a kereskedelemügyi m. kir. miniszter hozzájárulásával a vallás- és közoktatásügyi m. kir miniszter 1895. évi augusztus hó 20-án 44.001. sz. alatt kelt. Rendeletével. M. kir. Tud. Egyetemi Nyomda, Budapest, 1895.

Ábrai Lajos (1887): A kereskedelmi szakoktatás Németországban és Ausztriában. In: Ábrai Lajos (szerk.): Az Államilag Segélyezett Aradvárosi Kereskedelmi akadémia második évi jelentése az 1886-1887. iskolai évről. Arad. 3-33.

\footnotetext{
16 A hazai felső kereskedelmi iskolák területi megoszlását, tanulóinak felekezeti, társadalmi összetételét, valamint a korabeli munkaerőpiacon való elhelyezkedési lehetőségeit lásd bővebben (Nagy A., 2014. 165-242. o.)

17 1899. évi költségvetés tárgyalásakor Wlassics Gyula beszédében kiemelte, hogy „az állami és nemzeti egység elöfeltételét a kulturális intézményekben, a hazafias érzésekben, a közös törekvésekben és egységben összeforrott magyar nemzeti kultúra képezi" (Felkai, 1994. 15. o.).
} 
Bricht Lipót (1896): A Budapesti Kereskedelmi Akadémia története alapításától 1895-ig. Singer és Wolfner, Budapest.

Eötvös József (1880): A középtanodai oktatásról és a középtanodákhoz kapcsolódó szakiskolákról szóló törvényjavaslat indoklása. Országos Közép (tanodai) Iskolai Tanáregyesület Közlönye, 13. 15. sz. 284-311.

Jourdan, Édouard - Dumont, Georges (ed. 1886): Étude sur les écoles de commerce en Allemagne, en Autriche-Hongrie, en Belgique, en Russie, en Suède, en Suisse et aux États-Unis D'Amerique. Libraire II. Le Soudier, Paris.

Kereskedelmi szakiskoláink 1892/93-ban. Kereskedelmi Szakoktatás, 1893. 1. 7. sz. 212-217.

Koltai Virgil (1899): A kereskedelmi iskola a magyar közoktatás keretében. Kereskedelmi Szakoktatás, 8. 3-4. sz. 99-103.

Koltai Virgil (1903): Az osztrák kereskedelmi akadémiák látogatottsága. Kereskedelmi Szakoktatás, 11. 6. sz. 250.

Léautey Eugène (1886): L'Enseignement commercial et les écoles de commerce en France et dans le monde entier. Nomenclature et monographies des écoles de commerce françaises et étrangères d'après des documents officiels, observations et considérations sur l'enseignement commercial. Réformes. Librairie Comptable et Administrative, Paris.

Magyar Nemzeti Levéltár Országos Levéltára (MNL OL) Kereskedelemügyi Minisztérium (KM) K231. Ipari és belkereskedelmi szakosztály, 4. tétel, 138. doboz, 1890-1895.

Magyar Statisztikai Évkönyv (=MSÉ). Új Folyam XVIII. 1910. Magyar Királyi Központi Statisztikai Hivatal, Athenaeum, Budapest. 1911.

Pólya Jakab (1896): A Pesti Polgári Kereskedelmi Testület és a Budapesti Nagykereskedők és Nagyiparosok Társulata története. Franklin-Társulat Nyomdája, Budapest.

Szántó Sámuel (1895): Iskoláink autonómiája és fizetésügye. Kereskedelmi Szakoktatás, 4. 2-3. sz. 52-61.

Varga Imre (1890): A francia kereskedelmi iskolák. In: Ábrai Lajos (szerk.): Az Államilag Segélyezett Aradvárosi Kereskedelmi Akadémia ötödik évi jelentése az 1889-90. iskolai évről. Arad. 32-66.

\section{FELHASZNÁLT IRODALOM}

Bonin, Hubert (2006): Histoire de la Société général 1864-1890. La naissance d'une banque moderne. Droz S.A, Genève.

Cocks, Geoffrey - Jarausch, Konrad H. (1990): German professions, 1800-1950. Oxford University Press. New York.

Ditchen, Henryk (2015): Die Politechnika Lwowska in Lemberg: Geschiechte einer Technischen Hochschule im multinationalen Umfeld. Logos Verlag Berlin, Berlin.

Bódy Zsombor (2006): Mobilitás és iskolarendszer. A felső kereskedelmi iskolák helyéről a magyar iskolarendszer társadalomtörténetében. A Budapesti 
Kereskedelmi Akadémia diákságának rekrutációja és mobilitása, 1860-1906. In: Kövér György (szerk.): Zsombékok. Középosztályok és iskolaválasztás Magyarországon a 19. század elejétől a 20. század közepéig. Századvég, Budapest. 757-784.

Borotvás-Nagy Sándor (1928): Franciaország kereskedelmi szakoktatása. Kereskedelmi Szakoktatás, XXXV. évf. 5-6. sz. 210-244.

Fridenson, Patrick - Paqui, Lucie (2008) De haut enseignement commercial á l'enseignement supérieur de gestion (XIX.-XX. siècle). Simon, Pierre (szerk.): La Chambre de commerce et d'industrie de Paris 1803-2003. II. Études Thématiques. Droz S. A., 199-258.

Engwall, Lars - Zamagni, Vera (ed. 1998): Management Education in Historical Perspective. Manchester University Press, Manchester, New York.

Felkai László (1994): Magyarország oktatásügye a millennium körüli években. OPKM, Budapest.

Graves, N. J. (1964): Technical education in France in the nineteenth century. The origins and development of education for industry and commerce in France during the first 80 years of the nineteenth century in the public pirmery and secondary schools. The Vocational Aspect of Education, 34. 14. sz. 148-160.

Horlebein, Manfred (1991): Kaufmännische Berufschildung. In: Berg, Christa (szerk.): Handbuch der deutschen Bildungsgeschichte. Band IV. 1870-1918. Von der Reichsgründung bis zum Ende des Ersten Weltkrieges. Verlag C. H. Beck, München, 404-409.

Katus László (2012): A modern Magyarország születése. Magyarország története 1711-1914. Kronosz Kiadó, Pécs.

Lenormand, Paul (2008): Le chambre de commerce et d'industrie de Paris (1803-2003). Droz S.A, Genève.

Mann Miklós (1982): Trefort Ágoston élete és müködése. Akadémiai Kiadó, Budapest.

Nagy Adrienn (2015): Kereskedelmi iskolák az oktatáspolitika és a munkaerőpiac képviselőinek kereszttűzében 1850 és 1906 között. Képzés és Gyakorlat, 13. 3-4. sz. 153-168.

Nagy Adrienn (2014): A felső kereskedelmi iskolák fejlődéstörténete Magyarországon 1867-1945. Doktori Disszertáció. Kézirat. PTE „Oktatás és Társadalom” Neveléstudományi Doktori Iskola. Pécs.

Nagy Adrienn (2011): Polgári leányiskolák sorsa a dualizmus kori Magyarországon. In: Hajdicsné Dr. Varga Katalin (szerk.): Nevelés és társadalom: Hagyomány és megújulás. Képzés Gyakorlat Konferenciák V. Kaposvári Egyetem Pedagógiai Kar Nyugat-Magyarországi Egyetem Benedek Elek Pedagógiai Kar, Kaposvár. 201-218.

Nagy Péter Tibor (1998): Tantervpolitika a századvégen. Educatio, 7. 4. sz. 657-677.

Nagy Péter Tibor (2000a): A húszas évek középiskola-politikájának kialakulása. Századok, 134. 6. sz. 1313-1334. 
Nagy Péter Tibor (2000b): Járszalag és aréna. Egyház és állam az oktatáspolitika erőterében a 19. és 20. századi Magyarországon. Új Mandátum, Budapest.

Rätzer, Manfred (2001): Kurze Geschichte der Öffentlichen Handelslehransatlt Leipzig. In: Listewnik, Petra (Hrsg.): Die Öffentliche Handelslehransatlt zu Leipzig 1831-1950. Festschrift zum 170. Jahrestag ihrer Gründung. Leipziger Universitätsverlag, Leipzig.

Prévor, André (1964): Les Frères des Écoles Chrétiennes et la Pédagogie de 1'Enseignement Technique au 18e et au 19e siècles. Paedagogica Historica, 4. 171-172.

Schack Béla (1929): Az osztrák két osztályú kereskedelmi iskolák. Kereskedelmi Szakoktatás, 36. 2. sz. 155-157.

Schack Béla - Vincze Frigyes (1930): Kereskedelmi oktatásügy fejlödése és mai állapota Magyarországon. Franklin-Társulat, Budapest.

Schneider, Dieter (2001): Betriebswirtschaftslehre. Geschietchte und Methoden der Wirtschaftswissenschaft. R. Oldenburg Verlag München Wien. München.

Szántó Jenő (1926): A francia kereskedelmi szakoktatás jelen állapota. Kereskedelmi Szakoktatás, 33. 3. sz. 122-126.

Zander, Herbert Gunter (2004): Gründung der Handelshochschulen im deutschen Kaiserreich (1898-1919). Inauguraldissertation zur Erlangung des Doktorgrades der Wirtschafts- und Sozialwissenschaftlichen Fakultät der Universität zu Köln. Bad Homburg.

Vincze Frigyes (1935): A középfokú kereskedelmi szakoktatásügy hazánkban és a külföldön a 19. század ötvenes éveitől napjainkig. Studium, Budapest.

Vincze Frigyes (1937): A szakoktatásunk múltja és jelene. Szepes és Urbányi, Budapest.

Vörös Katalin (2013): A szakoktatás-politika és modernizáció a 19. század végi Magyarországon. In: Baska Gabriella - Hegedús Judit - Nóbik Attila (szerk.): A neveléstörténet változó arcai. ELTE - Eötvös Kiadó, Budapest. 94-105.

Vörös Katalin (2017): Az iparoktatás külföldön. Kísérlet a dualizmus kori pedagógiai sajtó és iparoktatás-politika árnyalására. Századvég, 83. 1. sz. 81-99. 


\title{
A szegedi Városi Zeneiskola története 1935-1945 között
}

\author{
Pethő Villő - Gévayné Janurik Márta \\ Szegedi Tudományegyetem Zenemúvészeti Kar
}

\begin{abstract}
„Szeged város zenekultúrája nemcsak Szeged város ügye, hanem az országos zenekultúra jelentős tényezője. [...] Ha azonban tekintetbe vesszük, hogy Szeged városát általánosan fejlett kultúrája, egyetemi városi jellege és geográfiai elhelyezése egyenesen predesztinálja a Dél-vidék zenekultúrájának irányítására, úgy megállapíthatjuk, hogy e város zenei életének jelentősége messze túlnő a város határain és a megítélésben Szeged város zenekulturális hivatása éppoly fontos, mint magasabb színvonalon a székesfőváros, vagy az ország egyéb vidéki zeneközpontjainak hivatása. A város zenei életének irányítói teljes mértékben átérzik e kulturális feladat jelentőségét és tervszerú munkával szolgálják nemcsak a helyi, hanem az országos zenekultúra ügyét." - írta 1929-ben Pálfy József, a szegedi városi színház intendánsa és a Szegedi Filharmonikus Egyesület elnöke a Muzsika folyóirat 111. számában, melyet a szerkesztők Szeged zenei életének szenteltek (Muzsika, 1929. 7. o.).
\end{abstract}

A Szeged kulturális életében fontos szerepet játszó és a várost kiemelkedő vidéki zeneoktatási színhellyé tévő 1881-ben megalapított zeneiskola történetének egy rövid, ám rendkívül meghatározó időszakának bemutatására vállalkozik tanulmányunk. Eddig még nem publikált hagyatéki anyagok: levelek, írások felhasználásával szeretnénk a figyelmet felhívni a Belle Ferenc nevével fémjelzett 1935-1944 közötti időszak jelentőségére és eredményeire, melyek a város kulturális életének is fontos évei voltak.

\section{A ZENEISKOLA RÖVID TÖRTÉNETE 1945-IG}

A szegedi zenészekről először egy 1522-ből származó „tized lajstrom” tesz említést, amelyen az adót fizető zenészek nevei szerepeltek. ${ }^{1}$ Az első katonai zenekar a 17. században alakult, emellett a városban fóleg egyházi zenét játszó muzsikusok, együttesek múködtek. Az első olyan zenekart, mely egyházi és világi zenei szolgálatot is teljesített az 1720-as évek elején gróf Nádasdy Lász-

\footnotetext{
${ }^{1}$ Sypos Benedek, Dobos Imre, Lantos György, Cantor Imre.
} 
ló csanádi püspök ${ }^{2}$ szerződtette a városban tett látogatásakor. A kilenctagú zenekar 1724-re vált teljessé, a város ekkor határozta el, hogy külön szállást építtet a tagoknak, ahol zeneoktatás is folyt. Később már csak olyan zenészeket szerződtettek, akik zeneoktatást is vállaltak. A 18. században azonban egyre jellemzőbbé vált a magánoktatás. Az első zeneiskola az 1829-ben megalakult Szegedi Belvárosi Casino kezdeményezésére az 1830-as évek közepén-végén jött létre. ${ }^{3}$ Az eredeti cél a városi zenekar mellett egy polgári zenekar felállítása volt. Erre alapozva alakult meg aztán a Szegedi Hangászat-oskola, melynek múködését egy 1838-as keltezésú 16 oldalas alapszabályban rögzítették (Kristó és Farkas, 1985), és amelynek fenntartását részvényesek biztosították (Reizner, 1900). Az iskola a levéltári dokumentumok alapján öt évig múködött, majd 1864 újra magániskola lett, végül 1873-ban a fenntartását a város vette át. Az 1879-es árvízben az intézet teljes hangszer- és kottaállománya megsemmisült. Az 1876-tól múködő immár városi intézet teljes hangszer- és kottaállománya megsemmisült az 1879-es árvízben. A Városi Zenede 1880-ban, a város főbb intézményeinek újjászervezésével egy időben nyílt meg egy Széchenyi téren lévő bérházban, Langer Viktor zeneszerző ${ }^{4}$ vezetésével. 1882-ben az intézmény a Szeged Szabad Királyi Város által fenntartott közmúvelődési intézetek sorába került. Az 1883-84-es tanévtől az iskola vezetését Szögedi (Roth) Endre ${ }^{5}$, az 1872-től múködő Szegedi Dalárda megalapítója vette át (Gévayné és Kerekné, 2013).

Itt kezdte meg zenei tanulmányait Belle Ferenc, a zenede jogutódja, a Városi Zeneiskola 1935-ben megválasztott igazgatója is. A zenedéről így írt visszaemlékezésében: „... a városi zenede a templom másik oldalához csatolt épületben volt, bejárata a Templom térról nyílott. Ide valóban túlnyomórészt a jobb módú, úgynevezett középosztály gyerekei jártak, de ennek egyik, majdnem fő oka az volt, hogy a zenetanulás az akkori megjelölés szerint nem volt cikk, nem volt pálya, megélhetés. [...] A zenetanulás, mint az általános múveltség kiegészítője, szinte luxusszámba ment." (Belle, 1976. 13-14. o.). Szögedi halála után Király-König Péter ${ }^{6}$ lett az intézmény vezetője. A zeneiskola több szegedi épületben is múködött Király-König igazgatásának kezdetén, majd 1916 szeptemberében költözött az 1881-ben épített Tukats Ferdinánd-féle alapítványi ház

\footnotetext{
${ }^{2}$ Nádasdy László gróf, (1662-1729) 1710-től csanádi püspök. Átmenetileg Szeged székhellyel ő szervezte újjá a törökök alól felszabadult csanádi egyházmegyét.

${ }^{3}$ Érdekes, hogy a zeneiskola megalapítójának nevét és az alapítás pontos dátumát a különböző források különbözőképp adják meg. Reizner János Szeged történetét összegző múvében 1838-as megalapításról írt, alapítóként Miskolczy István aljegyzőt jelölve meg. (forrás: http://www .bibl . u-szeged.hu/reizner/03/3400.htm, online: 2015. augusztus 1.) Lugosi 1929-ben a Muzsikában megjelentetett Szeged zenei életének történetét összegző munkája (Lugosi, 1929b) szerint a zeneiskolát Tirnauer György regens chori 1836-ban alapította, melynek alapszabályát 1838-ban adták ki. Kristó Gyula és Farkas József munkájában (Kristó és Farkas, 1985) a zeneiskola megalapításának dátuma 1835.

${ }^{4}$ Langer Viktor (1842-1902), zeneszerző és zeneíró.

5 Szögedi (Roth) Endre (1847-1903) főreáliskolai énektanár, karnagy, a Szegedi Dalárda megalapítója és karnagya.

${ }^{6}$ Király-König Péter (1870- 1940) zeneszerző.
} 
felső emeletére. ${ }^{7}$ Bár Szeged város tanácsa már 1908-ban elhatározta, hogy egy Zenepalotát építtet, melyben a zeneiskola is helyet kapott volna (Reizner, 1900), a hangversenyteremként is szolgáló épület megépítésére soha nem került sor. Király-König és később az őt követô Belle igazgatása idején is próbálták az épületet a zeneiskola céljainak megfelelően átépíteni, további tantermeket és hangversenytermeket alakítottak ki.

\section{Belle Ferenc életútua}

Belle Ferenc Szegeden született 1891. június 21-én. Középiskoláit a szegedi piarista gimnáziumban, zenei tanulmányait a városi zeneiskolában kezdte meg Daubrawsky Viktor hegedûmúvésznél. 1909-ben egyszerre nyert felvételt a Zeneakadémia (hivatalos nevén: Országos Magyar Királyi Zeneakadémia) hegedú tanszakára, Kemény Rezső osztályába és iratkozott be a Pázmány Péter tudományegyetem jogi fakultására. A zeneakadémián általános zeneelméletre Kodály Zoltán tanította, a zenekari gyakorlatot pedig Hubay Jenő tartotta számára. Az iskolai szünetek is a pályára való készüléssel teltek: „Az iskolai szünetekben Fehér Gizellával, a kitûnő zongoristával folytattuk a kamarázást. Önálló hangversenyekkel szerepeltünk Makón és Hódmezővásárhelyen, de egy-egy kisebb számmal felléptünk rendezvényeken is. 1912-ben a Hungária termében játszottam először zenekarral, Fichtner Sándor vezénylete mellett a Mendelssohn-koncert első tételét." (Belle, 1976. 17. o.). 1914 júniusában kapta meg hegedútanári oklevelét. Az első világháború idején katonai szolgálatot teljesített és főhadnagyi rangot ért el. A háború végeztével 1919 nyarán letette az utolsó szigorlatát, államtudományi doktorátust szerzett és megkezdte a gyakorlást. Fellegvári (Fiedler) Walter gordonkatanárral és Fehér Gizellával zongoratriót alapított.

Még 1918-ban, a Szegedi Filharmonikus Egyesület alelnöke, az egyesület által szervezett szimfonikus zenekar egyik alapító tagja és állandó koncertmestere lett. Az együttes hivatásos és amatőr muzsikusokból, a 46. gyalogezred zenekarának tagjaiból és a Király-König Péter által polgári zenészekből szervezett Szegedi Zenekedvelők zenekarának tagjaiból állt össze. Első hangversenyükön 1919. január 23-án a Tisza Szálló dísztermében Fichtner Sándor vezényletével álltak színpadra (Pappné, 2009).

1919 szeptemberében Szeged város a Király-König vezette Városi Zeneiskola hegedútanárává nevezte ki. Belle tanári munkája mellett is tevékenyen részt vett Szeged zenei életében: rendszeresen lépett fel kamaraprodukciók tagjaként, a zenekar hangversenyein koncertmesterként. Jó kapcsolatokat ápolt a szegedi értelmiségiekkel, jó barátságban volt Balázs Béla családjával, Fleischer Antal és Fricsay Ferenc karmesterekkel, az 1921-ben Szegedre költöző kolozsvári egyetem

7 A Zeneiskola 1916-os beköltözését követően többször alakították át az épület helységeit az oktatási intézmény számára. Ma is ez az épület ad otthont a város zenei közép- és felsőoktatási intézményeinek: a Vántus István Gyakorló Zenemúvészeti Szakközépiskolának és a Szegedi Tudományegyetem Zenemúvészeti Karának. 
zenekedvelő professzoraival pedig rendszeresen muzsikált együtt (Belle, 1976). ${ }^{8}$ Az 1934-35-ös tanévben igazgatóhelyettesként az 1934 szeptemberétől betegszabadságon lévő Király-König Péter helyett ő látta el az igazgatói teendőket, az iskola értesítójét is ő adta közre. Bellét a város végül 1935. október 31-én nevezte ki az intézmény igazgatójává. Belle sokat tett a Király-König Péter idején már országosan elismertté váló zeneiskola pedagógiai és szakmai megújulásáért. Igazgatói és tanári teendői mellett továbbra is részt vett a város zeneéletében kamaramuzsikusként, és a Szegedi Kamarazenekar koncertmestereként.

A háború alatt többször teljesített katonai szolgálatot. 1944 márciusában, Szeged német megszállásakor négy gyermekével és feleségével elhagyta a várost. Először Kalocsára majd Faddra, végül a Tolna megyei Szedresre költözött. Itt 1944 decemberétől szolgálatot is teljesített, 1945 áprilisáig segítette az szovjet hadsereg ellátását, ellenőrizte a község környéki gazdasági munkák elindulását. Szegedre 1945 májusában tért vissza családjával. A zeneiskola igazgatójának 1944 novemberétôl Kollár Pált nevezték ki. Belle visszatérése után 1947-ig a hegedútanárként múködött az intézményben, majd ezt követően Orosházán és Makón tanított. A zeneiskolákban végzett munka mellett Belle tagja volt az 1945ben már Vaszy Viktor vezetésével koncertező színházi zenekarnak, majd ennek megszúntével a színházi zenekari tagokból, zenetanárokból és amatőrökből megalakított Paulusz Elemér vezette Szegedi Filharmonikus Zenekarnak. 67 évesen ment nyugdíjba. 1977. december 20-án bekövetkezett haláláig rendkívül aktív életet élt: a Tábor utcában múködő zeneiskolában helyettesítő tanár volt, emlékiratain, többek között a Városi Zeneiskola történetén dolgozott. ${ }^{9}$

\section{A ZENEISKOLA PEDAGógIAI PROGRAMJA}

A zeneiskola korábbi vezetői, Szögedi (Roth) Endre és Király-König Péter egyaránt sokat tettek azért, hogy az intézmény a város, a régió és az ország zenei és kulturális életében meghatározó, magas múvészi színvonalat képviselő intézménnyé váljék (Kerek, 2003). Ezt a munkát folytatta Belle Ferenc, akinek szinte valamennyi, az ô igazgatása idején kiadott értesítőben jelent meg a zeneiskola társadalmi és kulturális szerepéről, az iskola pedagógiai törekvéseiről szóló cikke, rövid írása. ${ }^{10} \mathrm{Az}$ első, 1935-36-os tanévről szóló értesítőben Belle három pontban összegezte a zeneiskolák legfontosabb feladatát: „A zeneiskolának három feladata van. Az első: szakszerúen előkészíteni és képezni azokat a nagytehetségú növendékeket, akiket adottságuk a zenei pályára vonz és predesztinál; a második: olyan jó amatőr muzsikusokat képezni, akik mint kamarazenészek és zenekari tagok a gyakorlati zeneéletnek hasznos és lelkes tagjai lehetnek; a

\footnotetext{
${ }^{8}$ A Kamarazene Kör később, már zeneiskolai igazgatósága alatt újból megalakult, és rendszeresen szervezett koncerteket, később hangversenysorozatokat is nagy sikerrel.

${ }^{9}$ A Somogyi Könyvtárban fellelhetôek ezek az írások.

${ }^{10}$ A korábbi értesítőkre ez nem jellemző, melyek szinte kizárólag csak az intézményhez köthető statisztikai adatokat közöltek.
} 
harmadik: zeneélvező, zenefogyasztó közönséget nevelni." (Belle, 1936b. 7. o.).

Összevetve egy korábbi, 1923-ból származó értesítőben megfogalmazott képzési célokkal (a tanulók színvonalas képzése, a kiemelkedően tehetségesek felkészítése az akadémiai osztályok elvégzésére) itt új elemek is kerültek be a zeneiskola nevelési céljai közé. Az első, hogy a helyi (amatőr) zenei együttesekben való közremúködésre alkalmas tudással kerüljenek ki az iskolából a diákok. Vagyis elsősorban az iskola múködését segítő város, illetve régió kulturális igényeit kell a zeneiskolának kiszolgálnia. A második új elem ezzel összefügg: ki kell nevelni azt a közönséget, aki akár a helyi zenészek, akár magas múvészi színvonalat képviselő hangszeres és énekes múvészek hangversenyeit látogatja majd. Belle szerint a feladatok közül a vidéki zeneiskolákra - így a szegedire is - két fontosabb teendő hárult: jó amatôr muzsikusokat nevelni, illetve „a zenemúvelés képességét és szeretetét a társadalomba belevinni" (Belle, 1936b. 10. o.). Ehhez a zenetanárok tervszerú szakmai és pedagógiai munkájára és a növendékek kitartására egyaránt szükség volt. Érdekes azt látnunk, hogy a mai nyelvhasználatban meglehetősen negatív jelentést hordozó amatőr kifejezés mit is jelentett ebben az időben: Belle idejében az számított jó amatőr muzsikusnak, aki 10-12 évi zenetanulás után „... legalább a második-harmadik akadémiai osztályt, a Zenemúvészeti Főiskola kívánalmait megközelítő alapossággal és előképzettséggel elvégezte" (Belle, 1936b. 7. o.).

Belle ugyanebben az írásában utalt arra, hogy Szeged város vezetőinek megbízásából egy, a zeneiskola megújítására vonatkozó, átfogó tervezetet is készített, mely „a legilletékesebb hatóság elé került” (Belle, 1936b. 7. o.). A Belle-hagyatékban fellelhető egy levél, melyen sem aláírás, sem dátum nem szerepel, a címzettje pedig Hóman Bálint dr., magyar királyi vallás és közoktatásügyi miniszter. A szövegben Belle említi az 1934-es középiskolai reformot, vélhetően a levél ezután keletkezhetett, elképzelhető, hogy erre a levélre tett utalást az értesítőben is. A levél pedig nem más, mint egy több lépésből álló reformterv a zeneiskolák tanárainak szakmai továbbképzésére, melyre azért is lehetett szükség, mert a zeneiskolák helyzete nem változott. Bár átfogó reformra Belle nem látott esélyt, úgy gondolta, hogy tervezetét a hasonló fenntartói háttérrel rendelkező egyetemi városokban: Debrecenben, Pécsett és Szegeden lehetne bevezetni. A tervezetben három pontban jelölte meg a szükséges változtatásokat: (1) speciális didaktikus ellenőrzés; (2) pedagógiai tanulmányok; (3) múvészi továbbképzés. Az első pontban a kijelölt vizsgabiztos látogatása helyett egy évente megszervezett, zenakadémiai tanárokból álló szakfelügyelői bizottsági látogatást tartott szükségesnek. A második pontban jelölt pedagógiai tanulmányokat Belle szerint a vidéki zenetanárok a Zeneakadémián végezhettek volna. Mivel sok okleveles tanár csak a tanárképző osztályokat végezte a Főiskolán, ezért indoklása szerint ilyen rövid idő alatt és csak egy tanár tanítását, módszereit látva ezek a fiatal tanárok nem nyerhettek a tanításról általános, átfogó képet. Tervezetében minden év májusában nyílt volna lehetőség a vidéki tanárok számára a Főiskolán hospitálni. A terv legkidolgozottabb pontja a 
harmadik, melynek célja a zenetanárok és a megfelelő előképzettséggel bíró zenemúvészek rendszeres továbbképzése. Programjában Belle az augusztus 2. és 23. közötti időszakban egy magyar nyaralóhelyen megtartandó tanfolyamot „szabad iskola”-ként írta le, melynek elvégzéséről a zenetanárok végbizonyítványt kaptak volna. A résztvevők számára hetente öt napon keresztül legalább négy óra elfoglaltságot tervezett, a részvétel feltételeként pedig legalább két, előadásra alkalmas zenemúvel való foglalkozást írt elő. A tanfolyam vezetőjének irányításával ezeken a múveken keresztül a legújabb technikai és pedagógiai kérdések megvitatására kerülhetett volna sor. E múvek hangversenyen való bemutatását is fontosnak tartotta, amelyre a kurzus második felében nyílt volna lehetőség. A tervezethez részletes költségvetés is kapcsolódott.

Bár a tervezet országos szinten nem valósult meg, Belle Ferenc próbálta elképzeléseit az igazgatása alatt álló szegedi zeneiskolába átültetni. Az 1937-38-as tanév eredményeit összegző értesítőben a következőket írta Újabb iskolatípus felé címú cikkében: „,.. meg kell, hogy változzék az általános felfogás a zeneiskolák feladatáról, ne egy „,tessék-lássék dilettantizmust fejlesztő intézetet, hanem olyan szakiskolát lásson, ahol nehéz, komoly munkával ugyan, de maradandó értékú tudást és múveltséget lehet és kell szerezni." (Belle, 1938b. 5. o.). A zeneiskola épületének 1939-es felújítása új program megfogalmazására is lehetőséget adott. Az 1939-es tervekben között az új tanszakok bevezetése, a hangversenyek számának növelése mellett a zenetanárok számára pedagógiai előadásokat szeretett volna tartani, valamint kiemelt feladatként jelölte meg a zeneiskola tankerületi központi szerepére való felkészülést is ${ }^{11}$ (Belle, 1939b). A zeneiskolában már korábban is figyelmet fordított a tanárok szakmai és pedagógiai továbbképzésére. Az 1936-37-es tanév folyamán tervezték, hogy az intézmény szakkönyvtárát pedagógiai és zenepedagógiai munkákkal bővítik ${ }^{12}$, az aktuális kérdéseket, a legújabb szakirodalmat és gyakorlati módszereket pedig előzetes munkaterv szerint megvitatják a tanári megbeszéléseken. 1937 januárjában a tanári karból többen is részt vettek az országos szakfelügyelő kezdeményezése nyomán megrendezett konferencián, melyen a zeneiskolai tanítás aktuális kérdéseit vitatták meg (Belle, 1937). 1938-ban a tantestület belépett a Magyar Nevelők Egyesületébe, ugyanekkor részt vettek az egyesület békéscsabai vándorgyưlésén is, a későbbiekben pedig szorosabb együttmúködést is terveztek (Belle, 1938b).

\section{A ZENEISKOLAI KÉPZÉS SZERKEZETÉNEK VÁLTOZÁSAI}

A zeneiskolai képzés szerkezetét már Király-König igazgatása alatt többször finomították. A legnépszerúbb zongora és hegedú szakokon a teljes képzés 9, később 11 évfolyamon keresztül folyt: az előkészítő évet követően hat további

\footnotetext{
${ }^{11}$ Az értesítő tanúsága szerint a korabeli kultuszminisztérium egyik terve volt, hogy a szegedi zeneiskolát tankerületi központtá teszik.

${ }^{12}$ Lugosi Döme 1929-es jelentésében a zeneiskola könyvtárában fellehető 40 db szakkönyvről írt.
} 
évfolyamot elvégző diákok közül a legtehetségesebbek ún. kimúvelési osztályokban folytathatták tanulmányaikat. A mélyvonós, fúvós hangszerek és a magánének képzési terve nagymértékben eltért ettől ${ }^{13}$. A korábban már említett zongora és hegedû szakok képzési szerkezete Belle Ferenc igazgatóságának kezdetén, 1935-ben a következő volt: az 5 alsó és az azt követő 5 középosztály sikeres elvégzése után a tehetségesnek bizonyuló növendékek 4 akadémiai osztályban tökéletesíthették tudásukat. A kimúvelési és akadémiai osztályok elvégzése után több növendék nyert felvételt a Zeneakadémiára, akik tanulmányaik végeztével múvészképesítést kaptak. Azok, akik tanulmányaikat Szegeden folytatták, a kimúvelési osztályok elvégzése után, vizsgadíj megfizetése mellett a Zeneakadémián vizsgázhattak és zenetanári oklevelet szerezhettek. Már Király-König Péter igazgatása előtt is fontos volt a zenede vezetői számára, hogy tananyagainak közzétételével fenntartóját és a város lakosságát meggyőzzék arról, hogy az intézmény szakmailag és pedagógiailag megfelelő oktatást nyújt. Király-König évekkel megelőzve a minisztérium előírásait, az általa tanított tantárgyak - elmélet, szolfézs, összhangzattan, formatan és moduláció - tananyagát a zeneakadémiai gyakorlatnak megfelelően változtatta meg. Az 1917-18-as tanévtől kezdődően bevezetett felvételi vizsgával biztosítani szerette volna, hogy zenei képzésre valóban alkalmas diákok kezdjék meg tanulmányaikat (Kerek, 2003).

A tananyag folyamatos megújítására Belle is törekedett. Az 1936-37-es tanévben a zongora tanszakon bevezette a Zeneakadémia megújított tantervét, a következő tanévtől tervezték, hogy a többi tanszak képzése is követi a zongora tanszaki változásokat. Az 1937-38-as tanévben az osztályozásban is követték a zeneakadémiai gyakorlatot: „,... rátértünk a zenemúvészeti főiskola ötfokú szabályozó rendszerére, amelyben a jeles már igen jó kalkulus, a kitûnő pedig a ténylegesen kiváló növendékek szorgalmának elismerése." (Belle, 1938b. 4. o.). A Belle-időszakban is többen tettek magánvizsgát a Zeneakadémián, illetve nyertek felvételt annak osztályaiba, melyek eredményeiról minden értesítőben beszámoltak.

A zeneiskola már korábban is több szállal kapcsolódott a zeneoktatás korabeli csúcsintézményhez, a Zeneakadémiához. Michalovich Ödön, a Zeneakadémia igazgatója, ${ }^{14}$ az ott végzett tehetséges növendékeket beajánlotta a jelentősebb zeneiskolák élére. Király-König Péter is így került Szegedre. Belle Ferenc, és korábbi szegedi hegedútanára, Daubrawsky Viktor szintén a Zeneakadémián szerezte diplomáját.

A Városi Zeneiskola a jelenlegi zeneiskolai rendszerrel összehasonlítva egyfajta átmenetet képviselt, mindamellett, hogy alapfokon képezte a kezdő növendékeket, a további osztályokban középfokú, majd az akadémiai osztályoknak

${ }^{13}$ Bővebben lásd még: Gévayné Janurik Márta és Kerekné Fekete Éva (2013): A Zenedétől a Zenemüvészeti Karig. Fejezetek a szegedi zeneoktatás történetéből dokumentumok és képek tükrében. Litofilm Nyomda, Szeged, 18. o.

14 1887-1919-ig állt Mihalovich Ödön (1842-1929) a Zeneakadémia élén. 
köszönhetően a képzés szerkezetében és tartalmában is kapcsolódott a Zeneakadémiához. A zeneiskola vezetésének azon törekvése, hogy a képzés színvonalában közelítsen a budapesti intézethez, nemcsak a jól képzett muzsikusok belső igényéből is következhetett, hanem a vidéki intézmény gazdasági érdeke is volt. A zeneiskola számára ugyanis nemcsak az 1925-1934 között múködő dr. Baranyi János magán zeneiskolája de az önállóan múködő magántanárok is konkurenciát jelentettek (Lugosi, 1929a).

\section{A ZENEISKOLA TÁRSADALMI SZEREPE}

Belle Ferenc, akárcsak elődei, pontosan tudta, hogy csak egy olyan intézmény maradhat fent és kaphat folyamatos anyagi támogatást a várostól, amely minél több és minél eredményesebb növendéket nevel ki, és amely aktív, akár meghatározó résztvevője a város és a régió kulturális életének.

Jól látta, hogy a város, sőt a régió zenei életében egyaránt fontos szerepet játszhat az intézmény. Az értesítőkből, de más írásaiból is kiderül, hogy tervszerúen igyekezett erre a szerepvállalásra is felkészíteni az iskolát és zenét tanító kollégáit. Belle egy, a tanári karhoz intézett beszédében ki is tért rá, hogy az intézmény fenntartása milyen nagy megterhelést jelent a városnak, és annak érdekében, hogy továbbra is támogatást kapjanak, még eredményesebben és még többet kell dolgozniuk. ${ }^{15}$ A zeneiskola sikerességének egyik titka a szülők megnyerése volt. Az 1936-37-es tanévről szóló értesítőben írnak arról, hogy a szülőket fel kell világosítani, miként gyakorolhatnak a növendékek minél helyesebben, gazdaságosabban, egyúttal eredményesebben otthon. A szülői értekezleten emellett nemcsak a gyakorlásról szóltak, de a tanári megbeszélések pedagógiai témáit is megosztották. A következő, 1937-38-as tanévben az új bizonyítvány, az index bevezetésének is az volt a célja, hogy így a növendékek tanulmányairól, előmeneteléről, szorgalmáról minél áttekinthetőbb képet adjanak (Belle, 1938a). Emellett szülőket is várták azokra a zeneismertető előadásokra, amelyeket 1936-37-es tanévtől kezdődően „tervszerűen” szerveztek a növendékek számára. A zeneismertető előadásokat az igazgató bevezetője nyitotta, majd az előadások végén a tanárok értekezletet tartottak. Az 1937-38-as tanév zeneismertető előadásai: Dr. Magyariné Vesztényi Gizella a zongoratanszak első ötévi tananyagából játszott gyakorlatokat és darabokat, melyekhez Antos Kálmán, az elméleti tárgyak oktatója tartott magyarázó előadást. Jónásné Baranyi Ilona A zongora technikája és a billentés címú tanulmányát olvasta fel. Perényi Pál „Az iskola a növendékek és a szülők viszonya" címmel tartott előadást. Erdélyi János a hegedûtanszak első hatévi anyagából adott elő múveket, melyeket pedagógiai és zenei magyarázatokkal látott el. Antosné Simkó Mária zongoratanár Chopin életéről és múveiről tartott előadást, Kollár Pál Chopin múveket játszott (Belle, 1938a. 13. о.).

\footnotetext{
${ }^{15}$ Belle hagyatékában található írás dátum és cím nélkül.
} 
Az értesítőkből kiderül, hogy mindemellett a szegény sorsú, tehetséges diákok támogatását is fontosnak tartották. Az iskola a várossal egyetértésben minden évben meghatározott számú növendéknek nyújthatott teljes, illetve fél tandíjmentességet. Az 1936-37-es tanévben a tanári kar segélyegyletet hozott létre, amely a szegény, de tehetséges növendékeket hangszerrel, hangszertartozékokkal vagy kottákkal támogatta (Belle, 1937). Többször szerveztek olyan koncerteket, melyek teljes bevételét a szegény diákok támogatására fordították.

A zeneiskola számára fontos volt, hogy a diákjai nyilvános hangversenyeken is bemutathassák tudásukat. ${ }^{16}$ Ezeket több helyszínen tartották: a zeneiskola nagytermében, a Tisza Szálló dísztermében vagy az Ipartestület márványtermében, de a magánének tanszak növendékei rendszeresen szerepeltek az Alsóvárosi Kultúrházban és a Szegedi Nemzeti Színházban is músorukkal. A zeneiskola kórusa és zenekara is több rendezvényen múködött közre. Lugosi Döme megjegyzi, hogy az 1920-as években jellemzően a városban megrendezett hangversenyek látogatottsága elég gyér volt, csak a „világsztárok”, illetve a Szegeden ismert és elismert múvészek koncertjeire ment el számottevő hallgatóság (Lugosi, 1929a).

Ezért is volt figyelemre méltó az a törekvés, hogy a zeneiskola tanárai az intézmény falain belül önálló hangversenyeken lépjenek fel. Az 1934-35-ös tanévben szervezték meg a Kamarazene Kört, melynek már az első évben négy hangversenye volt a zeneiskola nagytermében, ezeket a hangversenyeket az ezt követő években is rendszeresen megrendezték. Később a háborús években a hangversenyélet megszervezésében új utakat kellett keresni.

Az 1940-41-es értesítőben megjelent rövid tanulmányában Belle Ferenc arról írt, hogy a gazdasági és politikai változásokhoz a hangversenyéletnek is igazodnia kell. A közép-európai országok és Budapest gyakorlatát követve szükség lenne arra, hogy minél szélesebb tömegek számára olcsó és kedvelt hangversenyeket szervezzenek, melyeken keresztül a „kisfizetésú társadalom” vagy a munkásság köréből verbuválódott közönség számára nyújtanának színvonalas szórakozási lehetőséget (Belle, 1941b). Ezzel a céllal jött létre még 1934-35-ös tanévben a korábban említett Kamarazene Kör. 1941-ben ugyanezzel a céllal szervezték meg a szegedi Népmúvelési Bizottsággal együtt első bérleti hangversenysorozatukat részben meghívott múvészekkel, részben a zeneiskola tanárainak közremúködésével, melyre minden bérlet már elővételben elkelt.

A zeneiskola tanárai nemcsak az intézmény keretein belül szerepeltek szólistaként vagy kamarazenészként hangversenyeken, rendezvényeken. "A zeneiskolai tantestület tagjai tudatában vannak annak, hogy többszöri szereplésükkel és többoldalú tevékenységükkel együttesen szolgálják a város zeneéletének, a zeneiskolának, egyes társadalmi vagy kulturális célú megmozdulásoknak érdekeit éppúgy, mint saját múvészi érvényesülésüket, ezért az elmúlt év folyamán több ízben szerepeltek iskolán kívül. .." - adta hírül az 1942-43-as tanévről készített értesítő (Belle, 1943b. 5. o.). A tanárok közül többen egyébként - maga Belle

\footnotetext{
${ }^{16}$ A hangversenyek músorát az 1942-43. tanévig részletesen közlik az értesítők.
} 
is - más posztokat is betöltöttek, melyek szintén szoros kapcsolatban voltak a szegedi zenei élettel. Belle Ferenc a zeneiskola tanáraként, később igazgatójaként egyúttal a Filharmóniai Egyesület egyik alapító tagja és koncertmestere is volt. Antos Kálmán zeneszerző, orgonista pedig a szegedi dóm orgonistája és karnagya, valamint a Szegedi Dalárda és Oratóriumegyesület valamint a Szegedi Polgári Dalárda karnagya volt és emellett tanította a zeneiskolában az elméleti tárgyak nagy többségét.

Az értesítők szerint a zeneiskola nagytermében több szegedi zenei együttes is rendszeresen próbált: nemcsak a Kamarazene Kör, melynek az iskola tanárai is aktív tagjai voltak és az Antos vezette két dalárda, de a Filharmonikus Egyesület, az Egyetemi Énekkar és a Szegedi Városi Énekkar is itt tartották próbáikat.

Már a Király-König idején kiadott zeneiskolai értesítőkből kiderül, hogy nagy hangsúlyt fektettek a magyar szerzők múveinek tanítására és előadására. Rendszeresen közölték, mely szerzők hány múvét tanulták és játszották a diákok. Az 1930-as tanévben például a König vezette intézmény diákjai harmadik évfolyamtól kezdődően összesen 293 múvet tanultak magyar szerzőktől. ${ }^{17}$ Ezt a „hagyományt” Belle Ferenc idején is folytatták. Rendszeresen játszották többek között Antos Kálmán, Bartók Béla, Dohnányi Ernő, Hubay Jenő, Kacsóh Pongrác, Kazacsay Tibor, Kodály Zoltán, Lavotta Rezső, Liszt Ferenc, Molnár Antal, Popper Dávid és Weiner Leó múveit. A zeneiskola hangversenyein is gyakran játszottak magyar és ezen belül szegedi szerzőktől is. 1941 májusában a Király-König Péter emlékére szervezett koncerten kizárólag a mester múvei szólaltak meg (Belle, 1941b.4. o.).

\section{A ZENEISKOLA TANSZAKAI BELlE VEZETÉSE IDEJÉN}

Király-König Péter igazgatása alatt a népszerû zongora- és hegedûszakok mellett évről-évre további tanszakok indultak. Az 1907-08-as tanévtől kezdődően már gordonka, gordon, fuvola, klarinét, kürt és magánének szakokon egyaránt folyt az oktatás (Kerek, 2003). Az első világháború kitörésekor - mint arról már korábban írtunk - azonban a tanárok szolgálatteljesítése miatt a zeneiskola fúvós és nagybőgő osztályain a tanítás szünetelt. A kötelező és választható melléktárgyak struktúrája Király-König Péter igazgatása alatt szintén sokat változott, bővült. Fontos szerepet kapott a karének, a zenekari tanszak, a kamarazene melléktanszak, de lehetőség volt zongorát és éneket is melléktanszakként tanulni. Az elméleti tárgyak között elméleti alapismereteket, összhangzattant, zenetörténetet tanultak a növendékek. 1930-ban König az esztétika melléktárgyat is bevezette, melynek előadásait ő maga tartotta (Kerek, 2003). A háborús éveket követően, az 1920-as évek végén a zeneiskola még mindig csak négy tanszakon: zongora, hegedû, gordonka és magánének szakon képezte a növendékeket. A kötelező és

\footnotetext{
17 König Péter (1931): A szegedi Államilag Segélyezett Városi Zeneiskola Értesítője. 1930-1931. Szeged Városi Nyomda és Könyvkiadó R. - T. Szeged.
} 
választható melléktanszakok száma nőtt ebben az időszakban, elméletet, solféget, összhangzattant, formatant, modulációt, zenetörténetet tanulhattak, valamint karének, kamarazene és zenekari osztályokba járhattak a tanulók (Lugosi, 1929).

Belle Ferenc igazgatása alatt a tanszakok száma a korábbiakhoz képest kis mértékben bővült. Az 1934-35-ös tanévtől kezdődően, a korábbi zongora, hegedú, gordonka és magánének szak mellett nagybőgő és elmélet szakokon folyt a tanítás. A gordonszakosok létszámának növekedését segítette elő, hogy 1934 és 1943-között teljes díjmentességet élveztek, az elméletszakosokat pedig kevesebb tandíj megfizetése mellett „,kültag”-ként tartották számon; számuk elenyésző volt a többi tanszakéhoz képest. Az első világháború kezdetéig fúvós hangszereket $^{18}$ is találunk a tanszakok között. A háborús években ezek a tanszakok megszúntek, a későbbiekben a fúvós hangszerek oktatását sem Király-König Péternek, sem az őt követő Belle Ferencnek nem sikerült bevezetnie. Az 1936ban közreadott értesítőben Belle már kiemelte, fontos feladata az intézménynek, hogy újra induljanak a fúvós tanszakok, megfelelő zenészutánpótlást biztosítva a városban múködő zenekarok, kamaraegyüttesek számára. Ez azonban csak terv maradt, hiszen az 1937-ben és 1939-ben kiadott értesítők programszerú cikkeiben a fúvós tanítás újraindításának tervéről éppúgy olvashatunk. Ezen a téren változás csak a második világháború utáni években következett be (Gévayné és Kerekné, 2013).

A Belle-korszakban a választható és kötelező melléktárgyak köre nem változott lényegesen. Az elméleti, összhangzattani osztályok mellett megmaradtak a formatan és esztétika tantárgyak, a zenetörténet oktatása két kurzus, a magyar és egyetemes zenetörténet formájában történt. Emellett karének (kezdő és haladó), kamarazene és zenekari osztályok indultak még. Újdonság volt azonban, hogy 1936-37-es tanévben heti két alapismereti órát tettek kötelezővé a kezdő növendékek számára. Az intézkedés szükségességéről a következőképpen nyilatkozott a melléktárgyakat oktató Antos Kálmán: „A zeneiskoláknál bevezetett elméleti, összhangzattani, formatani, történeti stb. órák nem akadémikus nagyképúségből létrehozott felesleges külön megterhelést jelentenek a növendéknek, ellenkezőleg: a zenei nevelés kizárólag akkor lehet célravezető, ha a hangszertanulással párhuzamosan gondoskodás történik a zenei hallás és ritmusérzék rendszeres fejlesztéséről, valamint a zenével kapcsolatos ismeretek módszeres elsajátításáról.." (Antos, 1937. 14. o.).

\section{KISGYERMEKEK ZENEI NEVELÉSE A ZENEISKOLÁBAN}

A zeneiskolának nyilvánvaló érdeke volt, hogy minél több diákot iskolázzon be és azok minél hosszabb ideig tanuljanak zenét. Ezért a legfiatalabb korosztályt is szerették volna megnyerni: először az 1934-35-ös tanévről szóló értesítőben említik a 4-7 éves korú gyerekek számára szervezett „zeneovodai” foglalkozáso-

\footnotetext{
${ }^{18}$ Fuvola, klarinét, kürt, amely hangszereket katonazenészek tanítottak.
} 
kat. A cél az volt, hogy még az iskolába kerülés előtt megszerettessék a zenét a gyerekekkel, ha már ekkor kiderül, hogy a gyermek tehetséges, nagyobb eséllyel marad az intézet növendéke. Az előzetes tanulmányoknak köszönhetően a később iskolába kerülő gyermek számára pedig már nem olyan megterhelő a hangszertanulás, mintha egyszerre két iskolában kezdi meg tanulmányait. A foglalkozásokat Simkó Mária zongoratanárnő, az elméleti tárgyakért felelős Antos Kálmán felesége tartotta, aki a zeneóvodáról szóló cikkben kiemelte: „Tanulásról szó sincs, mégis a kis apróságok sok tudást sajátítanak el, mint azt az első év eredménye igazolta s közben mindegyikről meg lehet állapítani, milyen tehetséggel van megáldva hallás, ritmusérzék, emlékezet, fizikai adottság stb. szempontjából s azt, hogy milyen hangszer tanulására alkalmas, hajlamos." (Simkó, 1936. 12. o.). Ennek ellenére, a foglalkozások inkább hasonlíthattak a mai zeneiskolai előkészítőre: énekeltek, hallás- és ritmusfejlesztő gyakorlatokat végeztek, hangszertanuláshoz szükséges mozgásokat, hangjegyeket tanultak. Az értesítőkben is gyakran szerepelt a „zeneóvoda” mellett a „zenetanuláshoz előkészítő iskola” vagy csak „előkészítő iskola” elnevezés. A foglalkozások októbertől májusig tartottak, a májusi növendékhangversenyeken pedig rendszeresen tartottak a csoportok „zene-óvodai tanóra bemutatót”. Bár az első években sok jelentkező volt ebbe az osztályba (1936-37-es tanévben 27-en, az 1937-38-as tanévben 13-an), többen kimaradtak (1936-37-es tanévben 10, 1937-38as tanévben 9 növendék). Az 1937-38-as tanévről összeállított értesítőben Belle Ferenc a következőkre mutatott rá: „... fontos, hogy felismerje a társadalom, milyen nagy szükség van a gyermekek zenetanulására - ez vezet komolyabb eredményre." lényegesen alacsonyabb volt (Belle, 1938b. 4. o.).

Az 1938-39-es tanévben nem indítottak zeneóvodai csoportot. Ezután új tanárral és új elvek mentén szerették volna újrakezdeni a foglalkozásokat. Az 1938-39-es értesítőben olvasható cikkből, amely az új elképzeléseket volt hivatott bemutatni úgy tưnik, sokkal inkább az iskolai tanításra emlékeztető előkészítőt szerettek volna létrehozni, mintsem játékos órákat óvodás korú gyerekek számára. Tölgyesiné Renyé Anna énektanárnő, akit a város óradíjas tanárként alkalmazott a zenei előkészítő foglalkozások megtartására, „Zeneelőkészítő iskola a legújabb pedagógiai elvek alapján" címú írásában foglalta össze pedagógiai elképzeléseit és a csoportokkal kapcsolatos terveit. Renyé számára nyugat-európai, amerikai intézmények, valamint az ebben az időben Budapesten múködő hasonló csoportok, és a Debrecenben létrehozott „zeneelő́készíto mintaiskola” jelentett követendő példát. Ő maga 1938-ban részt vett Budapesten a Magyar Énekoktatók Országos Egyesületének szervezésében megrendezésre kerülő Fritz Jöde német zenepedagógus által tartott előadássorozaton, amely a gyermekek zenei neveléséhez kapcsolódó német elképzeléseket mutatta be, és amely szintén nagy hatással volt rá. „Vázolt tanulmányozott módszerek alapján, tovább Molnár Imre és Molnár Antal Zenemúvészeti Főiskolai tanár urak támogatásával gondolom egy ilyen - a rendes iskolán kívül a múvészi nevelés minden ágát felölelő, mégis a zenei előkészítést hangsúlyozó - zeneóvoda kialakítását és Szegeden való beve- 
zetését." - írta ${ }^{19}$ (Tölgyesiné, 1939. 16. o.). A zeneóvodába szeptemberben lehetett jelentkezni, a tanítást különböző korcsoportokban - 4-5 évesek, 6-8 évesek; 8-10 évesek; 11-15 évesek -, viszonylag magas óraszámban, heti háromszor két órában tervezték megindítani. Ezt követően a zeneóvoda sorsáról, programjáról nem tudunk sokat. Szintén a témához kapcsolódik az 1940-41-es tanévet összegző értesítőben megjelent tanulmány. Belle „A gyermek és a zene” címú írása a zenetanulás gyermekkorban való megkezdésének szükségességére hívta fel a figyelmet. Egyúttal kitért arra, hogy a gyermekek különböző képességeinek fejlettsége között nagy különbségek lehetnek, és e képességek közül a zenei képességek fejlettségének mértéke nehezen ellenőrizhető: „A gyermek képzetei csaknem minden területen könnyebben ellenőrizhetők, mint a hangok, a zene területén. [...] A zenében áll a legnagyobb nehézség előttünk..." (Belle, 1941c. 5. o.) A gyermekek zenei nevelése szempontjából két kiemelt feladatot fogalmaz meg: „Az első az éneklés, amely karének és bizonyos hallásvizsgáló foglalkozás. Ez egy külön probléma, amelyre vonatkozólag Kodály Zoltán dr. korszakalkotó irányelveket tartalmazó tanulmánya kell, hogy átalakítólag hasson." (Belle, 1941c. 6. o.) Az aktív énekes és hangszeres zenélés mellett a zene passzív befogadását is tervszerúen emelné a zenei nevelésbe: „A második rész a hangszeres zenével való megismerkedés passzív hallgatás vagy tanulás útján. [...] Tapasztalat szerint az utóbbi az elhanyagoltabb terület..." (Belle, 1941c. 6. o.) A zenei előkészítő osztályok kiépítésének kísérlete nem volt hosszú életú, az 1940-41-es értesítőben még olvasható a beiratkozás időpontja, a tandíj összege, de semmi további adatot nem közölnek a zeneóvodához kapcsolódóan. Az 1941-42-es és az 1942-43-as tanévekről szóló értesítőkben már a beiratkozás lehetőségéről sem tesznek említést. Az értesítőkben követhető, hogy zeneóvodai csoport csak a második világháborút követően, 1945-ben indult újra.

\section{A ZENEISKOLA TANÁRI KARA}

"A modern zeneiskola megteremtésével” - írja Lugosi a zeneiskola 1880-as alapítására célozva - „a tanerők felszabadultak a zeneszolgáltatási kötelezettség alól és így teljes idejüket a zeneoktatás ügyének szentelhették. Ennek megvolt az az áldásos hatása, hogy a zenei múvelődés jobban terjedt, de megvolt az a hátránya, hogy a zenekari múvek bemutatása háttérbe szorult" (Lugosi, 1929a, 29. о.).

1929-ben a Lugosi-jelentés közreadásának idején a zeneiskola tanári karába az igazgató Király-König Péteren kívül kilenc rendes tanár, egy helyettes és egy óraadótanár tartozott. Összesen heten rendelkeztek a Zeneakadémián szerzett tanári képesítéssel, öten pedig tanítási engedéllyel dolgoztak, különféle végzettségek alapján.

\footnotetext{
${ }^{19}$ Molnár Imre (1888-1977) zenei író, énekmúvész, énektanár, zenekritikus, a Zenemúvészeti Főiskola tanára; Molnár Antal (1890 - 1983) zenetörténész, zeneszerző és zeneesztéta, brácsamúvész, Kodály Zoltán egykori tanítványa.
} 
Belle igazgatósága idején a tanári kar létszáma jelentősen nem változott, általában 12-13 körül mozgott. Az 1940-41-es tanévről kiadott értesítőben közölt névsorból jól látható, hogy a tanárok nagy része tapasztalt, zeneakadémiai tanári végzettséggel rendelkező zenetanár, sokan közülük már Király-König idejében a zeneiskola tanárai, voltak.

A tantestülethez rövidebb-hosszabb időre óradíjas tanárok is csatlakoztak. Például az 1937-38-as értesítőből kiderül, hogy Baranyi Lilly 1938 szeptemberében kérte a polgármestert, amennyiben zongora szakra a kiírt létszám felett jelentkeznek növendékek, úgy óraadóként vegyék alkalmazásba. Ugyanebben az évben nyújtott be hasonló kérelmet Zucker Hilda okleveles zongoratanár is, ő azonban csak 1945-ben került be a tanári karba (Belle, 1938a.). ${ }^{20}$

Nemcsak az épület 1939-ben történő átalakítása, de a háborús évek is terheket róttak a tanári karra. Belle Ferenc és Perényi Pál többször vonult be katonai szolgálatra, az ő feladataikat ez idő alatt kollégáik látták el. A zeneiskola hangversenytermét a Népmozgalmi Hivatal, egy nagyobb termét pedig a Népiskolai Törzskönyvi Hivatal foglalta el. A tanítás a többi teremben zavartalanul folyt, a hangversenyeket a Tisza Szállóban és a zeneiskola próbatermében tartották. „... (N)övendékeink általános színvonala a megnehezedett élet és családi körülmények dacára sem maradt az előző évekéi mögött. A szülők érdeklődése és ezáltal a növendékek szorgalma és komolysága a már szinte túlterhelt tanárok munkáját is könnyebbé és eredményesebbé tette." - írta Belle Ferenc 1943-ban (Belle, 1943b. 5. o.).

\section{A ZENEISKOLA NÖVENDÉKEI}

Az 1920-as évek végén a zeneiskola növendékeinek száma Lugosi jegyzéke alapján 360 fő körül mozgott, a kimaradókról ez a dokumentum nem közölt adatot. Ebben az időszakban a növendékek zöme már három-négy éve tanult zenét, a növendékek többsége öt-hat éven keresztül folytatta tanulmányait. Lugosi statisztikája szerint tanulmányaik első évében körülbelül a növendékek $30 \%$-a hagyta abba a zenetanulást, a zeneiskolába felvettek közül a későbbiekben 2\% bizonyult „zeneileg képezhetetlennek”. A tanulók nagy többsége zongorázni tanult, ezután népszerúségben a hegedú következett, ezt követte a gordonka és magánének tanszakon tanulók száma (Lugosi, 1929a. 51-54. o.). ${ }^{21}$

A Belle Ferenc igazgatósága alatt kiadott értesítők alapján a tanulók létszáma egyértelmúen alacsonyabb volt (250-270 fő körül), és lassú növekedést mutatott 1935-1939 között. Az 1939-40. tanévtől érte el vagy haladta meg a növendékek száma a 300-at, az 1942-43. tanévi értesítőben pedig arról számoltak be, hogy a beiratkozott 335 növendék miatt a tanárok nagy része óraszámán felül is vállalt tanítást. Az értesítőkben pontosan megadták a kimaradt növendé-

\footnotetext{
${ }^{20}$ Később,1952-től az újjászervezett, csak alapfokú oktatást nyújtó zeneiskola igazgatója.

${ }^{21}$ Lugosi jegyzéke 1925 és 1928 közötti tanévekről közölt adatokat.
} 
kek számát is. Arról, hogy a növendékek közül hányan bizonyultak „zeneileg képezhetetlennek”, az értesítők nem közöltek adatot. Valószínúleg e tanulók számát csökkentette az időközben bevezetett felvételi vizsga is. A hangszerek népszerúségi sorrendje a Belle-korszakban sem változott sokat: legtöbben zongorázni tanultak, ezt követte a hegedú. A magánének szakosok száma ebben az időszakban már megelőzte a gordonkát választókét. A kiadott értesítők külön jelölték a már felsorolt hangszereket és magánéneket választó „rendes” növendékeket és a más szakokon elméleti tárgyakat, nagybőgőt tanuló és zeneóvodába járó „rendkívüli” diákokat, akiknek a száma lényegesen alacsonyabb volt. A „rendkívüli" diákok tandíja is különbözött a „rendes” diákokétól. A nagybőgő szakosok minden díjtól mentesen, teljesen ingyen tanulhattak az intézményben, ez az intézkedést nyilvánvalóan a hangszer kisebb népszerúsége indokolta. A zeneóvodáról már a tanulmány korábbi fejezetében szóltunk. 1935-36-os tanévtől kezdődően a zeneóvodába jelentkezők számát is közölték a „rendkívüli” növendékek között. Az 1936-37-es tanévben jelentkeztek ebbe a csoportba legtöbben, 27-en. Az ezt követő tanévekben a beiratkozók száma csökkent. Végül a képzés az 1940-es évek elejére meg is szúnt, és csak 1945-ben, a konzervatóriummá alakulás előkészületének tekinthető időszakban indult újra az 1946-ban kiadott értesítő szerint.

\section{ÖsSZEGZÉS}

Az 1935-1944 közötti időszak különféle dokumentumait áttekintve jól látható, milyen külső és belső események alakították a Városi Zeneiskola életét, a történelmi események milyen lépésekre késztették a Szeged zenei életében és zeneoktatásáért dolgozó szakembereket és vezetőket. Belle Ferenc elsősorban Szeged kulturális, azon belül zenei, és zenepedagógiai központi szerepének megerősítsét és megőrzését tûzte ki célul. Munkája nyomán tovább nőtt az intézmény képzésének színvonala, amely hozzájárult a szegedi zeneértő, zeneszerető közönség gyarapodásához, egyben azt is lehetővé tette, hogy a város zenei együtteseibe egyre színvonalasabb munka folyjon az intézményből kikerülő „amatőr zenészeknek”, zenészeknek köszönhetően .

\section{FELHASZNÁLT IRODALOM}

Antos Kálmán: Az elméleti oktatásról. In: Belle Ferenc dr. (1937): Szeged Szabad Királyi Város Zeneiskolájának 1936-37. tanévi értesítője. Széchenyi Nyomda, Szeged. 12-15.

Belle Ferenc dr. (1935): Szeged Szabad Királyi Város Zeneiskolájának 1934-35. tanévi értesítojje. Széchenyi Nyomda, Szeged.

Belle Ferenc dr. (1936a): Szeged Szabad Királyi Város Zeneiskolájának 1935-36. tanévi értesítője. Széchenyi Nyomda, Szeged. 
Belle Ferenc dr. (1936b): Zeneiskolánk jövő feladata. In: Belle Ferenc dr. (1936a): Szeged Szabad Királyi Város Zeneiskolájának 1935-36. tanévi értesítője. Széchenyi Nyomda, Szeged. 7-10.

Belle Ferenc dr. (1937): Szeged Szabad Királyi Város Zeneiskolájának 1936-37. tanévi értesítője. Széchenyi Nyomda, Szeged.

Belle Ferenc dr. (1938a): Szeged Szabad Királyi Város „Liszt Ferenc” Zeneiskolájának 1937-38. tanévi értesítője. Széchenyi Nyomda, Szeged.

Belle Ferenc dr. (1938b): Újabb iskolatipus felé. In: Belle Ferenc dr. (1938a): Szeged Szabad Királyi Város „Liszt Ferenc” Zeneiskolájának 1937-38. tanévi értesitője. Széchenyi Nyomda, Szeged. 3-6.

Belle Ferenc dr. (1939a): Szeged Szabad Királyi Város "Liszt Ferenc” Zeneiskolája 1938-39. tanévi értesító. Árpád Nyomda, Szeged.

Belle Ferenc dr: (1939b): A zeneiskola új épülete és új programja. In: Belle Ferenc dr. (1939a): Szeged Szabad Királyi Város „Liszt Ferenc” Zeneiskolája 1938-39. tanévi értesító. Árpád Nyomda, Szeged. 3-5.

Belle Ferenc dr. (1940): Szeged Szabad Királyi Város „Liszt Ferenc" Zeneiskolája 1939-40. tanévi értesíto. Árpád Nyomda, Szeged.

Belle Ferenc dr. (1941a): Szeged Szabad Királyi Város "Liszt Ferenc" Zeneiskolája 1940-41. tanévi értesító. Árpád Nyomda, Szeged.

Belle Ferenc dr. (1941b): A hangversenyélet korszerúsítése. In: Belle Ferenc dr. (1941a): Szeged Szabad Királyi Város „Liszt Ferenc” Zeneiskolája 1940-41. tanévi értesíto. Árpád Nyomda, Szeged. 3-4.

Belle Ferenc dr. (1941c): A gyermek és a zene. In: Belle Ferenc dr. (1941a): Szeged Szabad Királyi Város "Liszt Ferenc" Zeneiskolája 1940-41. tanévi értesíto. Árpád Nyomda, Szeged. 5-7.

Belle Ferenc dr. (1942): Szeged Szabad Királyi Város „Liszt Ferenc" Zeneiskolája 1941-42. tanévi értesíto. Árpád Nyomda, Szeged.

Belle Ferenc dr. (1943a): Szeged Szabad Királyi Város "Liszt Ferenc" Zeneiskolája 1942-43. tanévi értesító. Árpád Nyomda, Szeged.

Belle Ferenc dr. (1943b): Beszámoló. In: Belle Ferenc dr. (1943a): Szeged Szabad Királyi Város "Liszt Ferenc” Zeneiskolája 1942-43. tanévi értesíto. Árpád Nyomda, Szeged. 3-6.

Belle Ferenc (1976): Emlékeim. Somogyi-könyvtári múhely. 76. 1-2. sz. 1-35.

Gévayné Janurik Márta és Kerekné Fekete Éva (2013): A Zenedétől a Zenemüvészeti Karig. Fejezetek a szegedi zeneoktatás történetéböl dokumentumok és képek tükrében. Litofilm Nyomda, Szeged.

Kerek Ferenc (2003): A stájer havasoktól Szegedig. Doktori értekezés. Liszt Ferenc Zenemúvészeti Egyetem, Budapest.

Kollár Pál (1947): Szeged Város „Liszt Ferenc” Zeneiskolája 1946-47. tanévi értesítō. Haladás Nyomda, Szeged.

Kristó Gyula és Farkas József szerk. (1985): Szeged története II. 1686-1849. Szeged Megyei Városi Tanács megbízásából: Somogyi Könyvtár, Szeged. 
Lugosi Döme (1929a): A zenemüvelés Szegeden. Szeged szab. kir. Város Jelentése a Vallás és Közoktatásügyi Miniszterhez. Szeged Szab. Kir. Város Közönsége, Szeged.

Lugosi Döme (1929b): A szegedi zenekultúra története. Muzsika. Zenemüvészeti, zenetudományi és zenekritikai folyóirat. Felelős szerk: Papp Viktor, 111.sz. 10-51.

Muzsika. Zenemüvészeti, zenetudományi és zenekritikai folyóirat. Felelős szerk. Papp Viktor 1929. 111. szám

Pappné Kopasz Ildikó (2009): A város zenészei. A komolyzene szegedi követei a kezdetektől 1994-ig. In: Szegedi muzsikusok. Írások a város szimfonikusainak évtizedeiből. (Szerk. Tandi Lajos), Bába és Társai Nyomda, Szeged. 7-15.

Reizner János (1900): Szeged története 3. kötet. http: //www.bibl .u-szeged . hu/reizner/reizner.htm online: 2015. aug.

Simkó Mária (1936): A zeneovoda célja. Szeged Szabad Királyi Város Zeneiskolájának 1935-36. tanévi értesítője. Széchenyi Nyomda, Szeged. 11-13.

Tölgyesyné Renyé Anna (1939): Zene előkészítő iskola a legújabb pedagógiai elvek alapján. In: Belle Ferenc dr. (1939a): Szeged Szabad Királyi Város „Liszt Ferenc" Zeneiskolája 1938-39. tanévi értesitó. Árpád Nyomda, Szeged. 15-16. 